Argonne

ANL/EVS/AGEM/TR-09-11

\title{
Sitewide Monitoring at Agra, Kansas, June 2009
}

\section{Environmental Science Division}


About Argonne National Laboratory

Argonne is a U.S. Department of Energy laboratory managed by UChicago Argonne, LLC under contract DE-AC02-06CH11357. The Laboratory's main facility is outside Chicago, at 9700 South Cass Avenue, Argonne, Illinois 60439. For information about Argonne and its pioneering science and technology programs, see www.anl.gov.

\section{Availability of This Report}

This report is available, at no cost, at http://www.osti.gov/bridge. It is also available on paper to the U.S. Department of Energy and its contractors, for a processing fee, from:

U.S. Department of Energy

Office of Scientific and Technical Information

P.O. Box 62

Oak Ridge, TN 37831-0062

phone (865) 576-8401

fax (865) 576-5728

reports@adonis.osti.gov

\section{Disclaimer}

This report was prepared as an account of work sponsored by an agency of the United States Government. Reference herein to any specific commercial product, process, or service by trade name, trademark, manufacturer, or otherwise, does not necessarily constitute or imply its endorsement, recommendation, or favoring by the United States Government or any agency thereof. The views and opinions of document authors expressed herein do not necessarily state or reflect those of the United States Government or any agency thereof, Argonne National Laboratory, or UChicago Argonne, LLC. 


\section{Sitewide Monitoring at Agra, Kansas,} June 2009

by

Applied Geosciences and Environmental Management Section

Environmental Science Division, Argonne National Laboratory

June 2010

USDA 


\section{Contents}

Notation.

1 Introduction and Background ......

2 Sampling and Analysis Activities

2.1 Monitoring Well Sampling and Analyses........

2.2 Measurement of Groundwater Levels

2.3 Handling and Disposal of Investigation-Derived Waste

2.4 Quality Control for Sample Collection, Handling, and Analysis

3 Results and Discussion

3.1 Analytical Results for Volatile Organic Compounds in Groundwater Samples and Lateral Distribution of the Contaminants.

3.2 Groundwater Level Data......

4 Future Actions.

5 References

Appendix A: Joint Work Plan for Sitewide Monitoring, Agra, Kansas

Appendix B: Sequence of Activities during the May-June 2009 Sitewide Monitoring Event and Field Measurements on Groundwater Samples

Appendix C: Data from Pace Analytical Services for Wastewater Sample C-1

Appendix D: Quality Control Data.

D-1 


\section{Figures}

2.1 Proposed locations for joint yearly monitoring

2.2 Proposed locations of large-diameter borehole installations on the former CCC/USDA facility at Agra, with proposed locations for IM-related groundwater monitoring wells and soil gas monitoring wells....

2.3 Permanent groundwater sampling locations and data logger locations at Agra, as of June 2009

3.1 Distribution of carbon tetrachloride in groundwater at Agra, as determined in May-June 2009 annual sitewide monitoring....

3.2 Groundwater level elevations at Agra on July 30, 2009, as interpreted from automatically recorded data

\section{Tables}

1.1 Wells to be sampled in the annual sitewide monitoring and IM monitoring programs at Agra....

3.1 Results of CCC/USDA annual sitewide groundwater monitoring and IM-related monitoring in May-June 2009.

3.2 Summary of results of CCC/USDA sitewide groundwater monitoring in 2005-2009

B.1 Sequence of sitewide monitoring activities at Agra in May-June 2009

B.2 Field measurements made during sitewide monitoring in May-June

D.1 Quality control results for organic analyses of water samples by the purge-and-trap method at the AGEM Laboratory

D.2 Analytical results for quality control samples collected during sitewide monitoring in May-June 2009 


\section{Notation}

AGEM Applied Geosciences and Environmental Management

AS air sparging

BGL below ground level

${ }^{\circ} \mathrm{C} \quad$ degree(s) Celsius

CCC Commodity Credit Corporation

COC chain of custody

DO dissolved oxygen

EPA U.S. Environmental Protection Agency

$\mathrm{ft} \quad$ foot (feet)

gal gallon(s)

IM interim measure

in. inch(es)

KDHE Kansas Department of Health and Environment

L liter(s)

LDB large-diameter borehole

$\mu \mathrm{g} / \mathrm{L} \quad$ microgram(s) per liter

$\mu \mathrm{S} / \mathrm{cm} \quad$ microsiemen(s) per centimeter

$\mathrm{mg} / \mathrm{L} \quad$ milligram(s) per liter

$\mathrm{mL} \quad$ milliliter(s)

min minute(s)

$\mathrm{mV} \quad$ millivolt(s)

ORP oxidation-reduction potential

ppb part(s) per billion

PWS public water supply

SVE soil vapor extraction

TOC top of casing

USDA U.S. Department of Agriculture

VOC volatile organic compound 


\section{Sitewide Monitoring at Agra, Kansas, June 2009}

\section{Introduction and Background}

In 1985, carbon tetrachloride was discovered in the groundwater at Agra, Kansas, during routine sampling of public water supply wells. Two of Agra's four public water supply wells contained low but detectable levels of carbon tetrachloride; the concentrations in wells PWS-3 and PWS-4 exceeded the maximum contaminant level. These wells were removed from service in 1986, although they remain available for uses other than drinking water. Other public wells, outside the area of contamination, supply drinking water for the city of Agra.

In 1987-2005, the Kansas Department of Health and Environment (KDHE) and the Commodity Credit Corporation of the U.S. Department of Agriculture (CCC/USDA) conducted investigations to delineate the contaminant plume and to identify source areas for the contamination — which results from the past use of grain fumigants containing carbon tetrachloride. Source areas were identified on the former CCC/USDA grain storage facility property and on the Producers Agricultural Marketing Association, Inc., property located to the south (Argonne 2006). The contaminant plume extends to the southeast, toward well PWS-3, from the identified source areas.

Both the CCC/USDA and Pro-Ag Marketing are currently implementing KDHEapproved interim measures (IMs). To address the contamination identified on its former property, the CCC/USDA is implementing a source control IM consisting of large-diameter boreholes (LDBs) coupled with soil vapor extraction (SVE) and air sparging (AS). Pro-Ag Marketing plans to use groundwater extraction to address the downgradient plume. The CCC/USDA and Pro-Ag completed installation of the two interim measures in May 2009 and August 2009, respectively. The performance and assessments of the effectiveness of the IMs are being reported separately by the responsible entities.

As part of the IM process, the KDHE (2008) requested the development of a joint sitewide groundwater monitoring plan to allow periodic assessment of the effectiveness of the separate IMs being implemented by the CCC/USDA and Pro-Ag, through monitoring of the level of contamination and the resulting change in both the extent and internal configuration of the downgradient plume. A Joint Work Plan for Sitewide Monitoring was developed by the CCC/USDA through its technical consultant, Argonne National Laboratory, and was reviewed, 
approved, and signed by Pro-Ag Marketing and subsequently submitted to the KDHE on May 12, 2009.

The KDHE (2009a) provided comments on the Joint Work Plan on May 27, 2009, requesting submission of a revised version. To minimize delays, the KDHE allowed the CCC/USDA to proceed with the scheduled annual sampling proposed in the Joint Work Plan. The sampling was to be conducted according to the previously approved low-flow sampling methodology (Argonne 2009). Argonne conducted the first annual sampling event for the CCC/USDA on June 15-16, 2009. The finalized, signed version of the Joint Work Plan provided to the KDHE on November 9, 2009, is in Appendix A.

Table 1.1 lists the monitoring and public water supply wells to be sampled under the Joint Work Plan, plus the wells being sampled to monitor the respective IMs. The entity responsible for each monitoring element is indicated, along with well completion dates and well registration numbers.

The subject of this report is the initial sitewide groundwater sampling event that occurred on June 15-16, 2009, under the Joint Work Plan. 
TABLE 1.1 Wells to be sampled in the annual sitewide monitoring and IM monitoring programs at Agra.

\begin{tabular}{|c|c|c|c|c|c|c|c|c|}
\hline \multirow[b]{2}{*}{$\begin{array}{c}\text { Sampling } \\
\text { Responsibility }\end{array}$} & \multirow[b]{2}{*}{ Well } & \multirow[b]{2}{*}{ Well Type } & \multirow{2}{*}{$\begin{array}{l}\text { Casing } \\
\text { Diameter } \\
\text { (in.) }\end{array}$} & \multicolumn{3}{|c|}{ Depth (ft BGL) } & \multirow[b]{2}{*}{$\begin{array}{l}\text { Completion } \\
\text { Date }\end{array}$} & \multirow[b]{2}{*}{$\begin{array}{l}\text { Registration } \\
\text { Number }\end{array}$} \\
\hline & & & & $\begin{array}{l}\text { Screen } \\
\text { Interval }\end{array}$ & $\begin{array}{l}\text { Flter Pack } \\
\text { Interval }\end{array}$ & Total & & \\
\hline \multicolumn{9}{|c|}{ Joint sitewide monitoring - 11 wells } \\
\hline Joint & KMW02 & Monitoring & 2 & $57-97$ & $20-97$ & 99 & 9/30/1987 & 45580 \\
\hline Joint & $\mathrm{MW}-\mathrm{C}$ & Monitoring & 2 & $35-55$ & $33-55$ & 55 & 6/3/1997 & 118623 \\
\hline Joint & $\mathrm{MW}-\mathrm{H}$ & Monitoring & 2 & $43-53$ & $41-53$ & 53 & $6 / 5 / 1997$ & 118620 \\
\hline Joint & MW-J & Monitoring & 2 & $54-66$ & $54-66$ & 66 & $6 / 13 / 1997$ & 118618 \\
\hline Joint & MW-L & Monitoring & 2 & $66-76^{a}$ & $64-76^{a}$ & 80 & 6/14/1997 & 118616 \\
\hline Joint & MW-M & Monitoring & 2 & $54.5-68.5^{b}$ & $52.5-68.5^{b}$ & 75 & $6 / 15 / 1997$ & 118510 \\
\hline Joint & MW-R & Monitoring & 2 & $46.5-66^{c}$ & $40-66^{c}$ & 66 & $2 / 25 / 1998$ & 353498 \\
\hline Joint & SB23S & Monitoring & 1 & $49-55$ & $48-55$ & 55 & $5 / 10 / 2001$ & 321229 \\
\hline Joint & SB36 & Monitoring & 4 & $42.7-62.7$ & $40-64.7$ & 62.7 & 7/15/1996 & 108165 \\
\hline Joint & PWS-3 & Public & 12 & $65-125$ & - & - & $4 / 30 / 1954$ & - \\
\hline Joint & DW98 & Domestic & 8 & - & - & 59.5 & - & - \\
\hline \multicolumn{9}{|c|}{ Monitoring for CCC/USDA source area IM - 8 wells } \\
\hline CCC/USDA & KMW03 & Monitoring & 2 & $74-89$ & NR & 89 & 10/2/1987 & 45583 \\
\hline CCC/USDA & MW-P & Monitoring & 2 & $39.5-59^{d}$ & $34-59^{d}$ & 59 & 2/25/1998 & 353496 \\
\hline CCC/USDA & MW-Q & Monitoring & 2 & $49.5-69^{e}$ & $44-69^{e}$ & 69 & 2/25/1998 & 353497 \\
\hline CCC/USDA & GW-1 & Monitoring & 1 & $43-53$ & $41-53$ & 53 & $7 / 1 / 2009$ & 426347 \\
\hline CCC/USDA & GW-2 & Monitoring & 1 & $43-53$ & $41-53$ & 53 & $7 / 1 / 2009$ & 426346 \\
\hline CCC/USDA & GW-3 & Monitoring & 1 & $43-53$ & $41-53$ & 53 & 7/1/2009 & 426345 \\
\hline CCC/USDA & GW-4 & Monitoring & 1 & $43-53$ & $41-53$ & 53 & $7 / 1 / 2009$ & 426344 \\
\hline CCC/USDA & GW-5 & Monitoring & 1 & $43-53$ & $41-53$ & 53 & $7 / 1 / 2009$ & 426343 \\
\hline \multicolumn{9}{|c|}{ Monitoring for Pro-Ag source area $I M-13$ wells } \\
\hline Pro-Ag & KMW01 & Monitoring & 2 & $43-53$ & $20-63$ & 63 & 10/7/1987 & 45581 \\
\hline Pro-Ag & MW-2 & Monitoring & 2 & $39-59^{f}$ & $37-59^{f}$ & $59^{f}$ & $5 / 31 / 1997$ & 118626 \\
\hline Pro-Ag & MW-F & Monitoring & 2 & $65-75^{g}$ & $64-75^{g}$ & $75^{\mathrm{g}}$ & 6/2/1997 & 118622 \\
\hline Pro-Ag & MW-G & Monitoring & 2 & $89-99$ & $87-99$ & 100 & 6/13/1997 & 118621 \\
\hline Pro-Ag & MW-I & Monitoring & 2 & $36-71$ & $34-71$ & 71 & $6 / 4 / 1997$ & 118619 \\
\hline Pro-Ag & MW-O & Monitoring & 2 & $38-58$ & $36-58$ & 58 & 8/29/1997 & 119090 \\
\hline Pro-Ag & PMW-01 & Monitoring & 2 & $49-59$ & $47-59$ & 59 & $8 / 21 / 2009$ & 427877 \\
\hline Pro-Ag & PMW-02 & Monitoring & 2 & $49-59$ & $47-59$ & 59 & $8 / 21 / 2009$ & 427825 \\
\hline Pro-Ag & PMW-03 & Monitoring & 2 & $52.5-62.5$ & $50.5-62.5$ & 62.5 & $8 / 21 / 2009$ & 427824 \\
\hline Pro-Ag & PMW-04 & Monitoring & 2 & $53-63$ & $51-63$ & 63 & 8/21/2009 & 427963 \\
\hline Pro-Ag & PMW-05 & Monitoring & 2 & 54.5-64.5 & $52.5-64.5$ & 64.5 & $8 / 21 / 2009$ & 427962 \\
\hline Pro-Ag & PMW-06 & Monitoring & 2 & $49-59$ & $47-59$ & 59 & $8 / 21 / 2009$ & 427964 \\
\hline Pro-Ag & PMW-07 & Monitoring & 2 & $70-75$ & $68-75$ & 75 & $8 / 21 / 2009$ & 427961 \\
\hline
\end{tabular}

a Reported screen interval for MW-L $=70-80 \mathrm{ft} \mathrm{BGL}$; reported filter pack interval $=68-80 \mathrm{ft} B G L$.

b Reported screen interval for MW-M $=59-69 \mathrm{ft} \mathrm{BGL}$; reported filter pack interval $=57-75 \mathrm{ft} \mathrm{BGL}$.

c Reported screen interval for MW-R $=44.45-63.95 \mathrm{ft} \mathrm{BGL}$; reported filter pack interval $=38-66 \mathrm{ft}$ BGL.

d Reported screen interval for MW-P = 35.42-54.92 ft BGL; reported filter pack interval $=31-59 \mathrm{ft} \mathrm{BGL}$.

e Reported screen interval for MW-Q $=43.28-62.78 \mathrm{ft} \mathrm{BGL}$; reported filter pack interval $=38-69 \mathrm{ft} \mathrm{BGL}$.

9 Reported screen interval for MW-F $=65-75 \mathrm{ft} \mathrm{BGL}$; reported filter pack interval $=63-85 \mathrm{ft}$ BGL; total depth $=$ $85 \mathrm{ft}$ BGL. 


\section{Sampling and Analysis Activities}

\subsection{Monitoring Well Sampling and Analyses}

The sitewide groundwater sampling event conducted by the CCC/USDA on June 15-16, 2009, involved the 11 designated joint sitewide groundwater monitoring wells (marked with purple boxes in Figure 2.1), plus wells MW-P, MW-Q, and KMW03 (being sampled by the CCC/USDA to monitor its IM - also shown in Figure 2.1). Per agreement with the KDHE (2009b), the May 2009 results for the 5 groundwater wells installed on the former CCC/USDA property to monitor the source control IM (GW-1 through GW-5) are considered part of the June 2009 annual monitoring event; resampling of those wells in June was not required, although the water levels were measured. Wells GW-1 through GW-5 lie close together in the CCC/USDA remediation area, near well MW-P; they are shown in Figure 2.2.

The May-June sampling began with measurement of water levels in the monitoring wells. Low-flow groundwater sampling techniques were then used to purge and sample the wells in accordance with U.S. Environmental Protection Agency (EPA) guidelines (Puls and Barcelona 1996; Yeskis and Zavala, 2002). The low-flow sampling of monitoring wells involved the use of a bladder pump and field measurement equipment designed to determine when representative formation water was entering the well screen. Stabilization of formation water in the screened area of the well was determined by measuring the static water levels and monitoring the levels of $\mathrm{pH}$, temperature, specific conductivity, oxidation-reduction potential (ORP), and dissolved oxygen (DO) during pumping through the in-line flow cell.

The following procedure was followed for each well sampled:

1. A bladder pump was inserted into the well to a depth midway between the top and bottom of the screen. To minimize disturbance of the solids that are typically present at the bottom of a well, care was taken not to lower the pump to the bottom of the casing.

2. The pumping rate for the bladder pump was set to ensure that minimal drawdown occurred in each well during pumping. The rate was monitored by measuring the static water level periodically throughout pumping and was modified as appropriate to minimize fluctuations in water levels. 
3. Polyethylene tubing was used to connect the bladder pump to an in-line flow cell. Formation parameters, including $\mathrm{pH}$, temperature, specific conductivity, ORP, and DO, were measured continuously in the in-line flow cell during pumping. Measurements were recorded every 4 min until three successive measurements for each parameter were within a range indicating that the formation water was stable. The range for formation stabilization varies for each parameter, as follows: $\mathrm{pH}$, within 0.1 ; temperature, within $3 \%$; specific conductivity, within 3\%; ORP, within $10 \mathrm{mV}$; and DO, within $10 \%$.

4. After stabilization of the formation water parameters, the polyethylene tubing was disconnected from the in-line flow cell, and a representative groundwater sample was pumped through the tubing into laboratory-approved containers.

5. The polyethylene tubing for each well was kept and dedicated for reuse at that specific well. In addition, pumping rate data were recorded for each well as a reference for subsequent sampling events.

The sequence of activities during the May-June 2009 sampling event is summarized in Appendix B, Table B.1. The field measurements - depth, temperature, $\mathrm{pH}$, conductivity, DO, and ORP — recovered during the sampling event are in Appendix B, Table B.2.

Groundwater samples designated for analyses for volatile organic compounds (VOCs) were collected in appropriate laboratory containers, labeled, packaged, and chilled to $4^{\circ} \mathrm{C}$ by placement in ice-filled coolers. The samples were shipped via an overnight delivery service to the Applied Geosciences and Environmental Management (AGEM) Laboratory at Argonne for VOCs analyses with EPA Method 524.2 (EPA 1995). Aliquots of selected samples (chosen in the field) were also shipped to TestAmerica Laboratories, Inc., South Burlington, Vermont, for verification VOCs analyses according to EPA Contract Laboratory Program protocols.

The analytical results are presented and discussed in Section 3.1. 


\subsection{Measurement of Groundwater Levels}

In addition to the manual water level measurements made during the May-June 2009 sampling event, data recorders have been gathering long-term data on groundwater elevations at selected locations throughout the investigation area (Figure 2.3) since 2005. This effort continues to provide information regarding potential changes in groundwater flow and gradient that is useful in the interpretation of inferred downgradient movement of the carbon tetrachloride plume. The groundwater level data are presented and discussed in Section 3.2.

\subsection{Handling and Disposal of Investigation-Derived Waste}

Purge water generated as potentially contaminated investigation-derived waste was containerized on-site in 55-gal drums during the annual sampling event. The accumulated purge and development water (approximately 190 gal) was sampled on September 24, 2009, and analyzed at a KDHE-certified laboratory (Pace Analytical Services, Lenexa, Kansas) for VOCs (including ethylene dibromide) and nitrates. The analytical results are in Appendix C. The concentrations of carbon tetrachloride, chloroform, ethylene dibromide, and nitrate were below the KDHE standards. No VOCs were detected, and the nitrate value was $3.4 \mathrm{mg} / \mathrm{L}$. On November 18, 2009, the wastewater was taken to the Sabetha municipal water treatment facility for disposal, although KDHE (2009c) guidance would permit its release on the site.

\subsection{Quality Control for Sample Collection, Handling, and Analysis}

Quality assurance/quality control procedures followed during the June 2009 monitoring event are described in detail in the Master Work Plan (Argonne 2002). The results are summarized as follows:

- Sample collection and handling activities were monitored by the documentation of samples as they were collected and the use of chain-ofcustody forms and custody seals to ensure sample integrity during handling and shipment. 
- Samples designated for VOCs analyses were received with custody seals intact and at the appropriate preservation temperature. All samples sent to the AGEM Laboratory were analyzed within the required holding times.

- Quality control samples collected to monitor sample-handling activities (trip blanks and equipment rinsates) and method blanks analyzed with the samples to monitor analytical methodologies were all free of carbon tetrachloride and chloroform contamination.

- Groundwater samples were analyzed for VOCs at the AGEM Laboratory by the purge-and-trap method on a gas chromatograph-mass spectrometer system. Calibration checks analyzed with each sample delivery group were required to be within $\pm 20 \%$ of the standard. Surrogate standard determinations performed on samples and blanks, as shown in Appendix D, Table D.1, were within the specified range of $80-120 \%$ for all samples, in either the initial analysis or a successful reanalysis.

- Results from the AGEM Laboratory for dual analyses of the groundwater samples are in Appendix D, Table D.2. The results of the dual analyses compare well, with average relative percent difference values for carbon tetrachloride and chloroform of approximately 5\% and 13\%, respectively, indicating consistency in the sampling and analytical methodologies. Analytical results for quality control samples are also in Appendix D, Table D.2.

- In accordance with the procedures defined in the Master Work Plan (Argonne 2002), groundwater samples were submitted to a second laboratory (TestAmerica) for verification analysis according to the protocols of the EPA's Contract Laboratory Program. Documentation is in Appendix D. The results from the two laboratories compare favorably over the range of contaminant concentrations detected. 


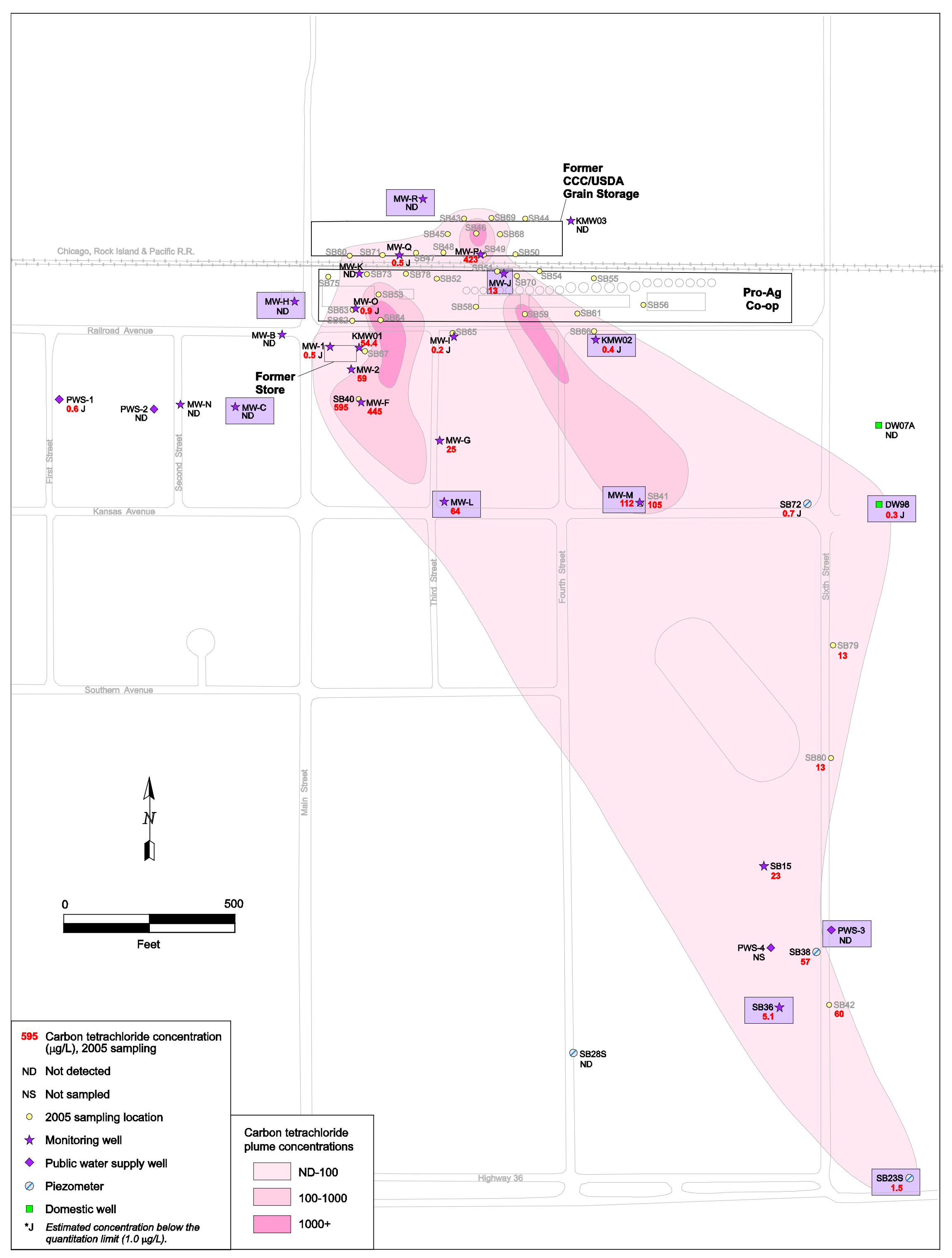

FIGURE 2.1 Proposed locations (purple boxes) for joint yearly monitoring. Also shown are wells KMW03, MW-P, and MW-O, which are sampled to monitor the CCC/USDA source control IM, and wells KMW01, MW-2, MW-F, MW-G, MW-I, and MW-O, which are sampled to monitor the Pro-Ag Marketing IM. 


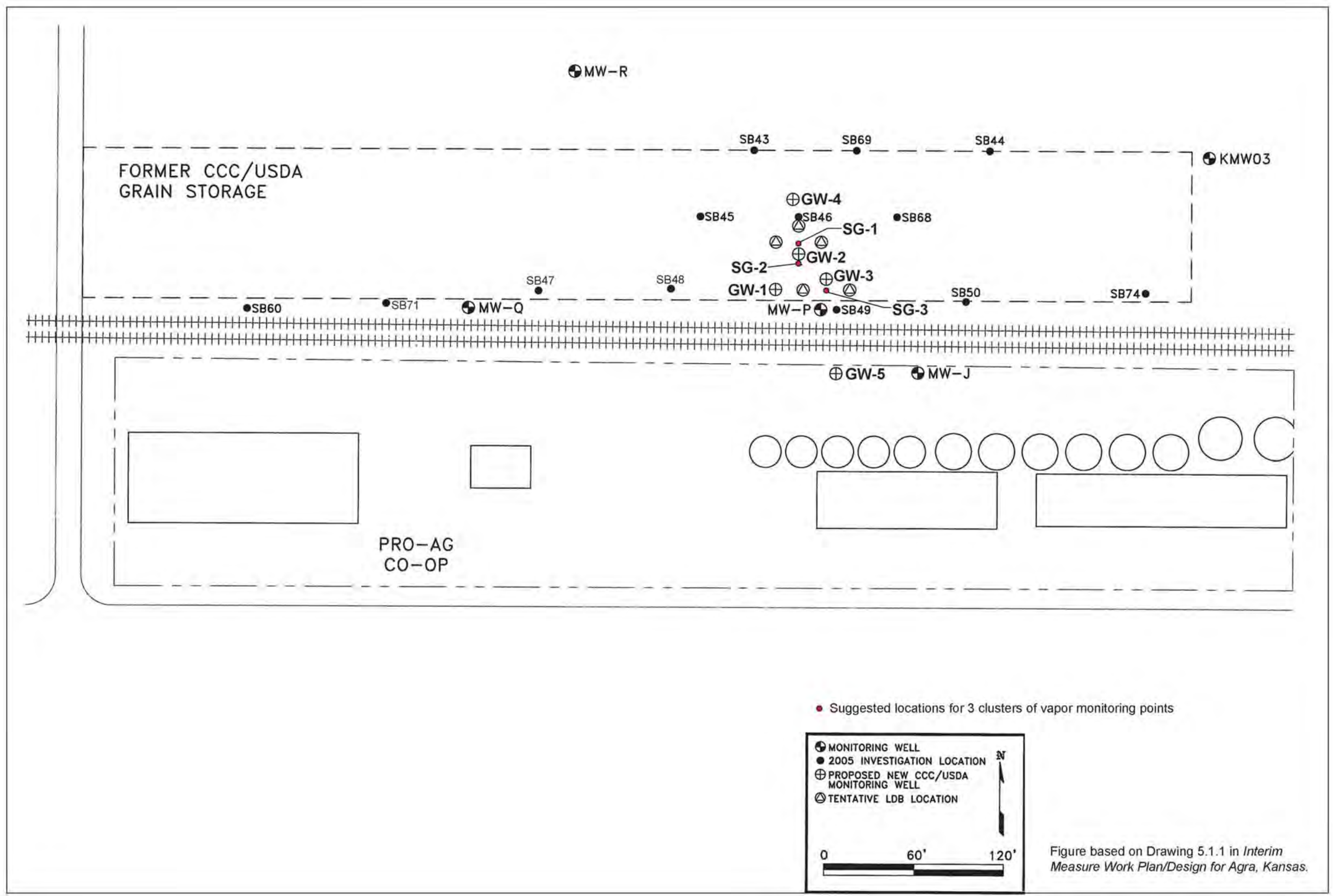

FIGURE 2.2 Proposed locations of large-diameter borehole installations on the former CCC/USDA facility at Agra, with proposed locations for IM-related groundwater monitoring wells and soil gas monitoring wells. 


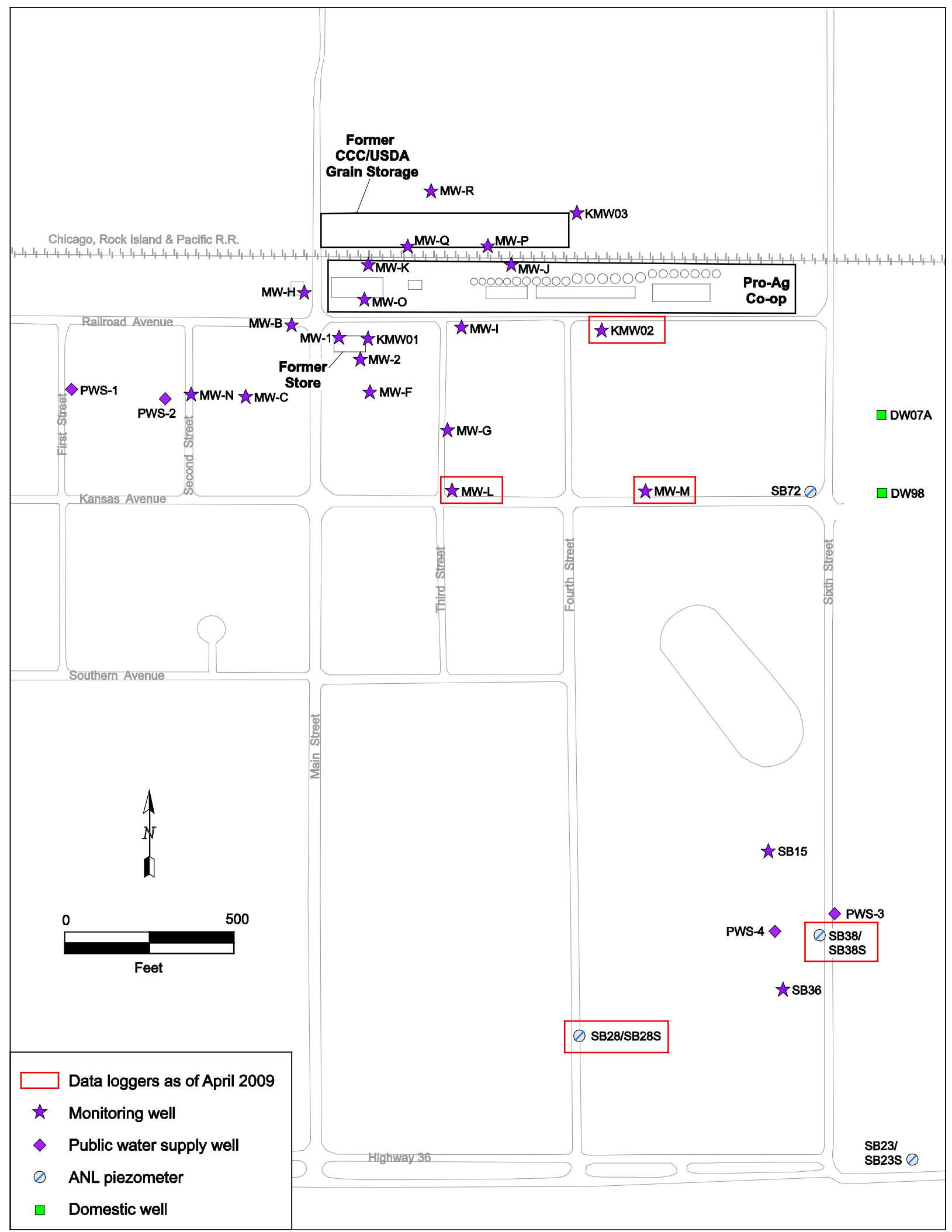

FIGURE 2.3 Permanent groundwater sampling locations and data logger locations at Agra, as of June 2009. 


\section{Results and Discussion}

\subsection{Analytical Results for Volatile Organic Compounds in Groundwater Samples and Lateral Distribution of the Contaminants}

The analytical data for VOCs in the groundwater samples collected by Argonne for the CCC/USDA in conjunction with the annual sitewide groundwater monitoring event in May-June 2009 are in Table 3.1. For comparison, Table 3.2 represents a comprehensive summary of CCC/USDA results for carbon tetrachloride and chloroform in groundwater, beginning with the 2005 targeted investigation and continuing through the October 2008 pre-remedial baseline study and the May-June 2009 sitewide monitoring. A map illustrating the current levels and distribution of carbon tetrachloride contamination in groundwater, based on the results of the May-June 2009 sitewide sampling, is in Figure 3.1. This map includes the locations of the September 2009 Pro-Ag Marketing monitoring well installations for the sake of completeness. A separate report of the results of the September 2009 sampling event will be provided to the KDHE by Pro-Ag.

Comparison of the carbon tetrachloride levels in groundwater during the 2008 preremedial baseline study and in May-June 2009, after the installation of the SVE/AS remedial system (Table 3.2), indicates mixed results to date. Installation of the LDB/SVE/AS pilot test was initiated in December 2008 and completed in January 2009. Subsequently, during the period May 13-16, 2009, five groundwater monitoring wells (GW-1 through GW-5) were installed on the former CCC/USDA property to track the performance of the approved pilot system. The official start-up date for the SVE/AS system was May 29, 2009.

At the time of the initial annual sitewide sampling event, the CCC/USDA pilot test had been in operation for a period of less than one month (May 29 to June 15-16, 2009). The sitewide monitoring in June 2009 was the initial sampling event (Table 3.2) for newly installed wells GW-1 through GW-5, at the treatment area locations shown in Figure 2.2. The nearest previous groundwater sampling occurred at location SB46 during the 2005 investigation. The maximum carbon tetrachloride concentration in groundwater at location SB46 in 2005 was 1,710 $\mu \mathrm{g} / \mathrm{L}$ (Argonne 2006). The higher concentrations measured in June 2009 in wells GW-2 (6,090 $\mu \mathrm{g} / \mathrm{L}$ ) and GW-3 $(9,198 \mu \mathrm{g} / \mathrm{L})$ are consistent with the interpretation illustrated in Figure 2.1 (based on the 2005 results) of a high-concentration area centered slightly to the south of location SB46. 
Continuing monitoring of the treatment area wells will indicate the progress of the CCC/USDA source control effort.

In general, the slight reductions in the levels of carbon tetrachloride observed in the downgradient wells nearest the remedial system could potentially be attributable to the effects of the SVE/AS system. Well MW-P, located along the southern margin of the former facility, exhibited a subtle reduction in contaminant levels, from $318 \mu \mathrm{g} / \mathrm{L}$ during the 2008 baseline study to $260 \mu \mathrm{g} / \mathrm{L}$ in the June 2009 sampling (Table 3.2). The proximity of MW-P to the recently installed SVE/AS remediation pilot could account for this early indication of contaminant reduction. Subsequent sampling events will be necessary to verify this hypothesis. Additional reductions noted in downgradient locations proximal to the pilot test area, such as MW-Q and MW-J, are too low to be considered of significance at this time (Table 3.2 and Figure 3.1).

The results of the May-June 2009 annual sampling event revealed more significant changes in the internal configuration and extent of the carbon tetrachloride plume than the subtle changes observed proximal to the remediation pilot test area on the former CCC/USDA facility. Results for monitoring wells MW-L and MW-M, located along the farthest extent of the bi-lobate plume structures internal to the plume, showed minor reductions in carbon tetrachloride levels from $64 \mu \mathrm{g} / \mathrm{L}$ to $23 \mu \mathrm{g} / \mathrm{L}$ and from $112 \mu \mathrm{g} / \mathrm{L}$ to $84 \mu \mathrm{g} / \mathrm{L}$, respectively, between 2005 and 2009.

The most significant changes were observed at locations farther downgradient. Public water supply well PWS-3, in which carbon tetrachloride had previously (2005) not been detectable, showed an increase to $7.6 \mu \mathrm{g} / \mathrm{L}$ in 2009 (Table 3.2); this concentration is above the KDHE risk-based standard for carbon tetrachloride. The concentration at location SB36 remained unchanged. The carbon tetrachloride concentration at location SB23S, at the farthest downgradient position (toe) of the plume as currently defined, increased, from $1.5 \mu \mathrm{g} / \mathrm{L}$ in the 2005 investigation to $59 \mu \mathrm{g} / \mathrm{L}$ during the 2009 annual sitewide sampling event (Table 3.2). This increase might indicate an extension of the plume to the southeast. Wells SB36, PWS-3, and SB23S were not sampled during the 2008 baseline event, as the scope of the targeted investigation at that time focused on the former CCC/USDA facility and its immediate environs. 


\subsection{Groundwater Level Data}

Observations made during interpretation of the results from the recent groundwater monitoring event indicate that the groundwater flow direction and gradients did not change significantly from that depicted in the report of the 2005 investigation (Argonne 2006), remaining consistent with a predominant groundwater flow direction to the south-southeast from the vicinity of the former CCC/USDA facility and the Pro-Ag Marketing facility. Groundwater elevation data were recovered on July 30, 2009. The water level contour map in Figure 3.2 confirms the south to southeasterly flow direction identified in previous investigations.

TABLE 3.1 Results of CCC/USDA annual sitewide groundwater monitoring and IM-related monitoring in May-June 2009.

\begin{tabular}{|c|c|c|c|c|c|c|c|}
\hline \multirow[b]{2}{*}{$\begin{array}{c}\text { Sampling } \\
\text { Responsibility }\end{array}$} & \multirow[b]{2}{*}{ Well } & \multirow[b]{2}{*}{$\begin{array}{l}\text { Sampling } \\
\text { Date }\end{array}$} & \multicolumn{4}{|c|}{ Concentration $(\mu \mathrm{g} / \mathrm{L})$} & \multirow{2}{*}{$\begin{array}{c}\text { Nitrate } \\
\text { Nitrogen } \\
(\mathrm{mg} / \mathrm{L})\end{array}$} \\
\hline & & & $\begin{array}{c}\text { Carbon } \\
\text { Tetrachloride }\end{array}$ & Chloroform & $\begin{array}{l}\text { Methylene } \\
\text { Chloride }\end{array}$ & $\begin{array}{c}1,2- \\
\text { Dichloroethane }\end{array}$ & \\
\hline Joint & KMW02 & $6 / 16 / 09$ & $0.2 \mathrm{~J}^{\mathrm{a}}$ & $0.3 \mathrm{~J}$ & $N D^{b}$ & ND & - \\
\hline Joint & MW-C & $6 / 15 / 09$ & ND & ND & ND & ND & - \\
\hline Joint & MW-H & $6 / 15 / 09$ & ND & $0.3 \mathrm{~J}$ & ND & ND & - \\
\hline Joint & MW-J & $6 / 16 / 09$ & 13 & $0.1 \mathrm{~J}$ & ND & ND & - \\
\hline Joint & MW-L & $6 / 16 / 09$ & 23 & 1.1 & ND & ND & - \\
\hline Joint & MW-M & $6 / 15 / 09$ & 84 & 1.5 & ND & ND & - \\
\hline Joint & MW-R & $6 / 15 / 09$ & ND & ND & ND & ND & - \\
\hline Joint & PWS-3 & $6 / 16 / 09$ & 7.6 & ND & ND & ND & - \\
\hline Joint & SB23S & $6 / 16 / 09$ & 59 & $0.8 \mathrm{~J}$ & ND & ND & - \\
\hline Joint & SB36 & $6 / 16 / 09$ & 5.1 & $0.4 \mathrm{~J}$ & ND & ND & - \\
\hline Joint & DW98 & $6 / 16 / 09$ & $0.4 \mathrm{~J}$ & $0.4 \mathrm{~J}$ & ND & ND & - \\
\hline Argonne & KMW03 & $6 / 16 / 09$ & ND & ND & ND & ND & - \\
\hline Argonne & MW-P & $6 / 16 / 09$ & 260 & 11 & ND & ND & - \\
\hline Argonne & MW-Q & 6/16/09 & $0.8 \mathrm{~J}$ & ND & ND & ND & - \\
\hline Argonne & GW-1 & $5 / 20 / 09$ & 114 & 8.1 & ND & ND & - \\
\hline Argonne & GW-2 & $5 / 20 / 09$ & 6090 & 46 & ND & ND & - \\
\hline Argonne & GW-3 & $5 / 20 / 09$ & 9198 & 28 & ND & ND & - \\
\hline Argonne & GW-4 & $5 / 20 / 09$ & 127 & 2.3 & ND & ND & - \\
\hline Argonne & GW-5 & $5 / 20 / 09$ & ND & ND & ND & ND & - \\
\hline
\end{tabular}

a Qualifier J indicates an estimated concentration below the quantitation limit of $1.0 \mu \mathrm{g} / \mathrm{L}$ for purge-and-trap analyses at the AGEM Laboratory.

b ND, not detected at instrument detection limit of $0.1 \mu \mathrm{g} / \mathrm{L}$ for analyses at the AGEM Laboratory or a reporting limit of $1.0 \mu \mathrm{g} / \mathrm{L}$ for analyses at Pace Analytical.

c 1,2 -Dichloroethane detected at $5.8 \mu \mathrm{g} / \mathrm{kg}$ in a soil sample collected during well installation at $49.5-50 \mathrm{ft}$ BGL. 
TABLE 3.2 Summary of results of CCC/USDA sitewide groundwater monitoring in 2005-2009,

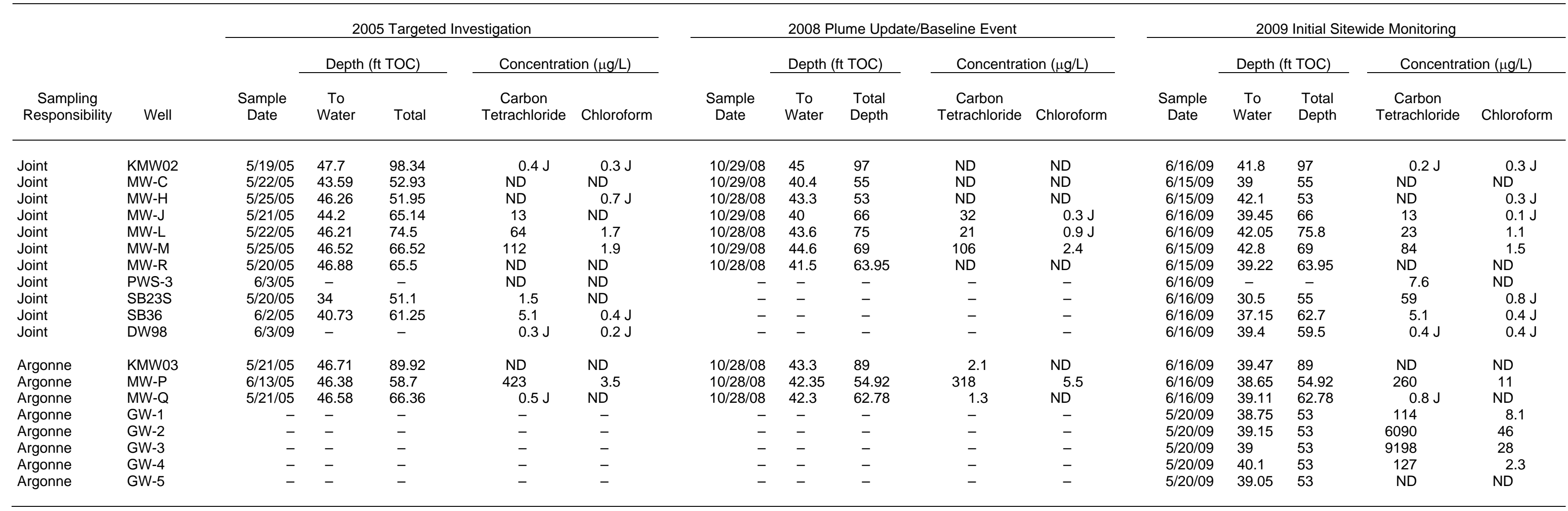




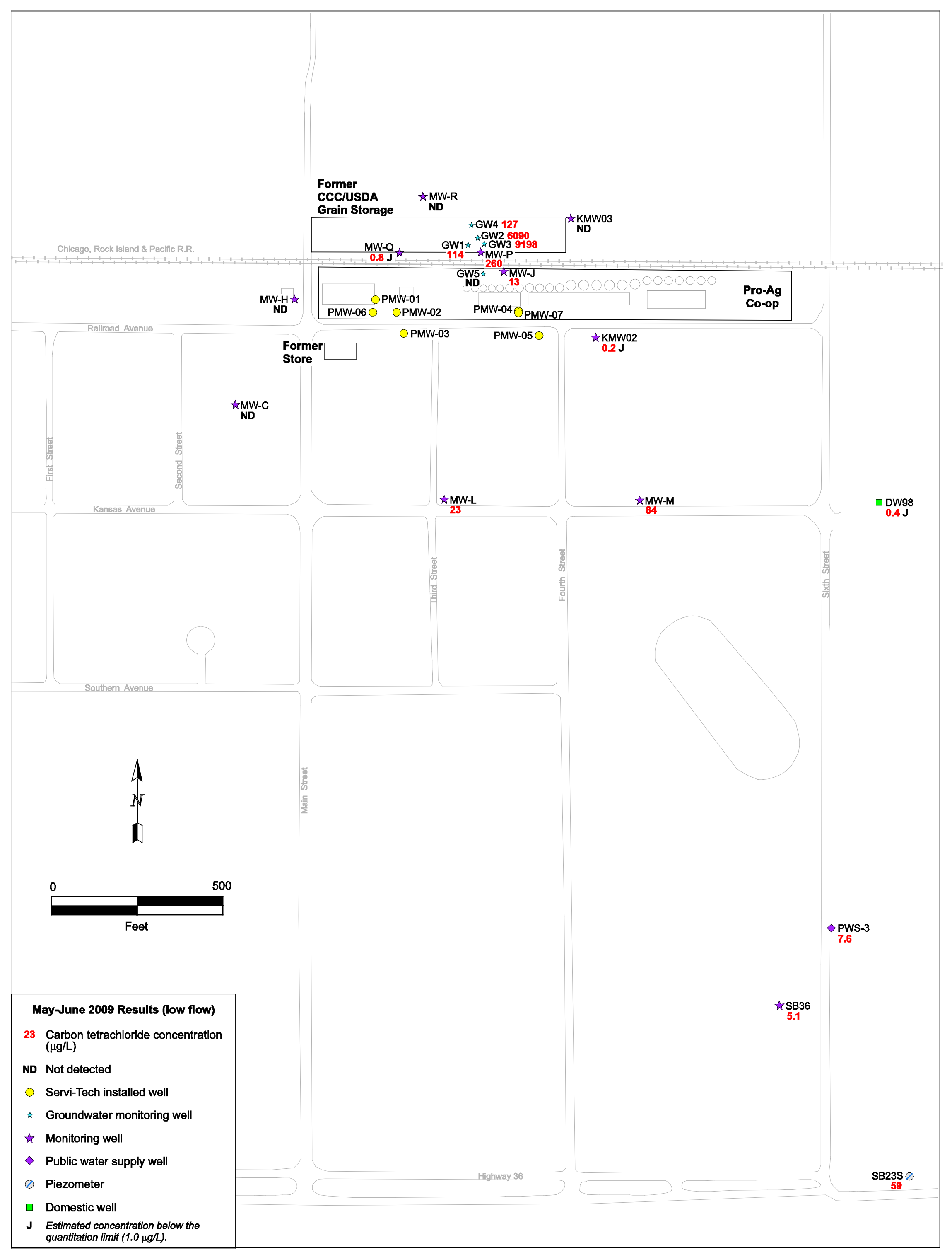

FIGURE 3.1 Distribution of carbon tetrachloride in groundwater at Agra, as determined in May-June 2009 annual sitewide monitoring. 


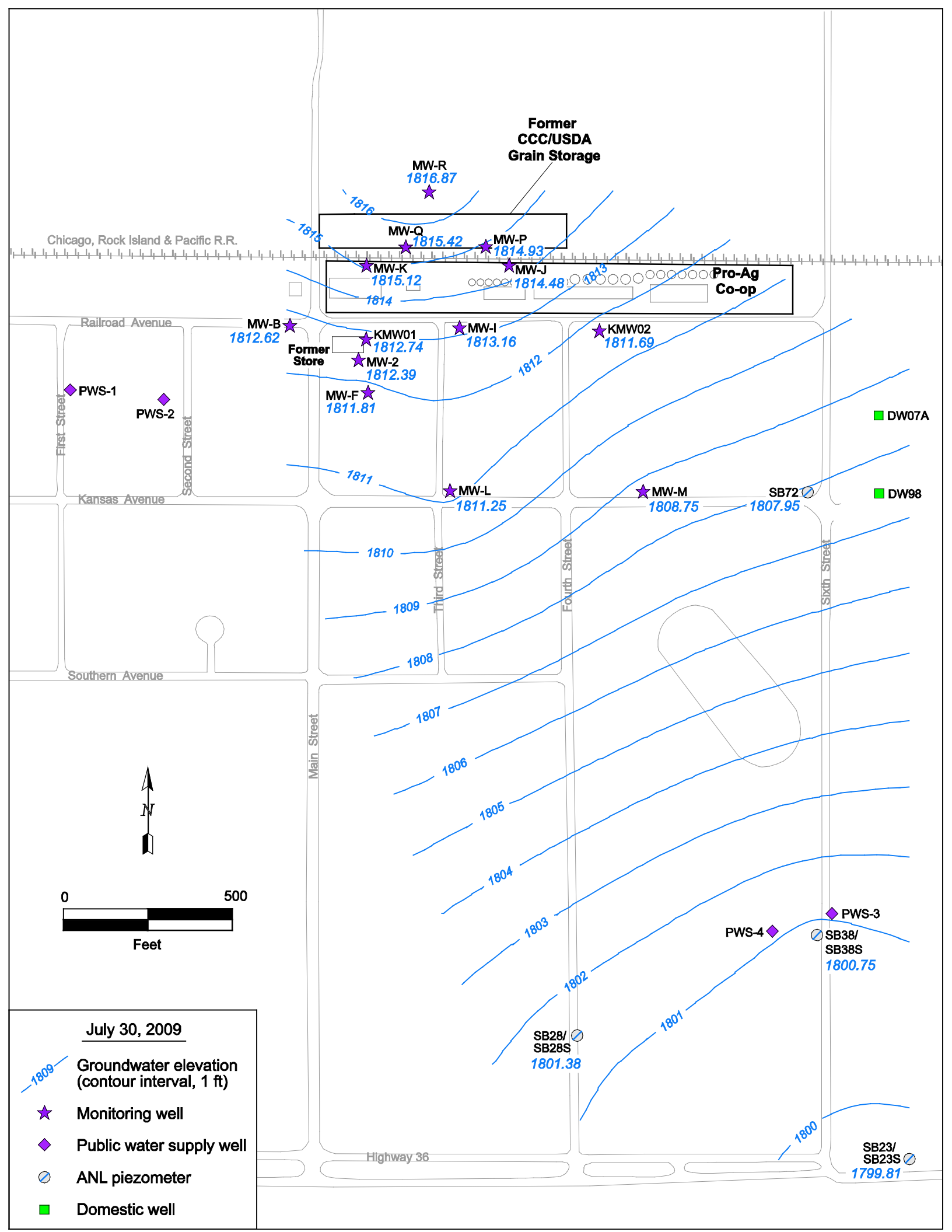

FIGURE 3.2 Groundwater level elevations at Agra on July 30, 2009, as interpreted from automatically recorded data. 


\section{Future Actions}

The next KDHE-approved joint sitewide groundwater monitoring event is scheduled for June 2010. In keeping with the joint agreement, Pro-Ag Marketing and its technical consultants will be conducting the sampling effort. The 2010 effort will include the wells to be jointly reported, as well as the monitoring wells installed in support of the Pro-Ag remediation efforts. 


\section{References}

Argonne, 2002, Final Master Work Plan: Environmental Investigations at Former CCC/USDA Facilities in Kansas, 2002 Revision, ANL/ER/TR-02/004, prepared for the Commodity Credit Corporation, U.S. Department of Agriculture, by Argonne National Laboratory, Argonne, Illinois, December.

Argonne, 2006, Final Report: Results of the 2005 Investigation of Contaminant Sources at Agra, Kansas, ANL/EVS/AGEM/TR-06-02, prepared for the Commodity Credit Corporation, U.S. Department of Agriculture, Washington, D.C., by Argonne National Laboratory, Argonne, Illinois, July.

Argonne 2009, Low-Flow Sampling Procedure, ANL/EVS/AGEM/CHRON-1227, prepared for the Commodity Credit Corporation, U.S. Department of Agriculture, by Argonne National Laboratory, Argonne, Illinois, February 2.

KDHE, 2008, letter from E. Finzer (Bureau of Environmental Remediation, Kansas Department of Health and Environment, Topeka, Kansas) to C. Roe (Commodity Credit Corporation, U.S. Department of Agriculture, Washington, D.C.), regarding the Interim Measure Work Plan/Design for Agra, November 21.

KDHE, 2009a, letter from E. Finzer and C. Jaeger (Bureau of Environmental Remediation, Kansas Department of Health and Environment, Topeka, Kansas) to C. Roe (Commodity Credit Corporation, U.S. Department of Agriculture, Washington, D.C.) and J. Jirak (Pro-Ag Marketing Association, Kensington, Kansas), regarding the joint sitewide monitoring plan for Agra, May 27.

KDHE, 2009b, electronic mail message from E. Finzer (Bureau of Environmental Remediation, Kansas Department of Health and Environment, Topeka, Kansas) to L.M. LaFreniere (Argonne National Laboratory, Argonne, Illinois), agreeing that wells GW1-GW5 did not need to be resampled in the sitewide monitoring event but requesting measurement of water levels in those wells, June 10.

KDHE, 2009c, electronic mail message from E. Finzer (Bureau of Environmental Remediation, Kansas Department of Health and Environment, Topeka, Kansas) to C. Roe (Commodity Credit 
Corporation, U.S. Department of Agriculture, Washington, D.C.) and L.M. LaFreniere (Argonne National Laboratory, Argonne, Illinois), with guidelines for handling of investigation-derived waste, October 29.

Puls, R.W., and M.J. Barcelona, 1996, "Low-Flow (Minimal Drawdown) Ground-Water Sampling Procedures,” EPA/540/S-95/504, in Ground Water Issue, Superfund Technology Support Center for Ground Water, National Risk Management Research Laboratory, U.S. Environmental Protection Agency, Ada, Oklahoma, April (www.epa.gov/tio/tsp/download/ lwflw2a.pdf).

Yeskis, D., and B. Zavala, 2002, Ground-Water Sampling Guidelines for Superfund and RCRA Project Managers: Ground Water Forum Issue Paper, EPA 542-S-02-001, Technology Innovative Office, Office of Solid Waste and Emergency Response, U.S. Environmental Protection Agency, Washington, D.C., May (http://www.epa.gov/tio/tsp/download/ gw_sampling_guide.pdf). 


\section{Appendix A:}

\section{Joint Work Plan for Sitewide Monitoring, Agra, Kansas}


Agra Joint Sitewide Monitoring

March 8, 2010

\section{Joint Work Plan for Sitewide Monitoring, Agra, Kansas}

\section{Background:}

The objective of CCC/USDA investigations at Agra in 1995-2005 was to characterize the subsurface geologic and hydrologic conditions that exist at and adjacent to the former facility, including conditions at the private grain storage facility directly to the south, which is currently operated by the Pro-Ag Co-op. During these investigations, the presence of carbon tetrachloride was identified at levels exceeding the Kansas Tier 2 Risk-Based Screening Level and the EPA maximum contaminant level of $5.0 \mu \mathrm{g} / \mathrm{L}$ in groundwater. The most recent comprehensive investigation of the presence, levels, and distribution of this contaminant in the soil and groundwater at Agra was conducted in 2005.

During the investigation conducted by Argonne in 2005 on behalf of the CCC/USDA, three soil source areas were identified. Figure 1 illustrates the locations of these sources, the distribution of investigation/sampling points, the analytical results, and the interpreted extent of the carbon tetrachloride plume emanating from these identified source areas. A single source was identified on the former CCC/USDA facility. Two source areas were likewise identified on the property to the south that is currently operated by the Pro-Ag Co-op.

In response to a KDHE request in a letter dated July 17, 2006, the CCC/USDA developed the document Interim Measure Conceptual Design for Remediation of Source Area Contamination at Agra, Kansas. Upon KDHE approval of the conceptual design, a second document, Interim Measure Work Plan/Design for Agra, Kansas, was submitted to the KDHE in August 2008 and approved on November 21, 2008.

The interim measure (IM) at Agra was implemented in December 2008 and January 2009. As presented to and approved by the KDHE, a system of large-diameter boreholes and associated soil vapor extraction and air sparging wells was installed at the former CCC/USDA facility as part of this action (Figure 2). The system is expected to be completed, tested, and operational in April 2009.

In recent months, Pro- $\mathrm{Ag}$ has been negotiating an IM plan for the Co-op property with $\mathrm{KDHE}$. The most recent draft received conditional approval from KDHE in March 2009.

\section{Proposed Monitoring Plan:}

As part of the IM process, the KDHE requested the development of a sitewide monitoring plan to allow periodic assessment of the success of the IM remediation system, as well as the level of contamination and potential changes in both the extent and internal configuration of the carbon tetrachloride plume. The KDHE envisioned that the proposed monitoring plan would be developed and implemented jointly by CCC and the Pro-Ag Co-op.

The CCC/USDA proposes to conduct groundwater sampling at the 11 locations shown in Figure 3, as follows: MW-R, MW-J, KMW02, DW-98, PWS-3, SB23S, SB36, MW-C, MW-H, 
MW-M, and MW-L. Pro-Ag will sample the same locations. The frequency of monitoring will be yearly. The CCC/USDA will take the initial round of samples in June 2009, coincident with the CCC/USDA IM monitoring program. Pro-Ag will sample the following year (June 2010). Argonne will arrange for access at these locations, as necessary, for sampling by the CCC/USDA and Pro-Ag. The CCC/USDA will sample in odd-numbered years beginning in 2009, and the Pro-Ag Co-op will sample in even-numbered years beginning in 2010. After 2010, modifications to the locations and schedule will be negotiated if results of the monitoring program warrant.

In the case of the CCC/USDA, additional groundwater data will be available and presented from. the CCC/USDA IM monitoring program (Figure 2). In addition to the 11 locations to be sampled as proposed above, the following wells will be also be sampled per the CCC/USDA IM monitoring program: groundwater monitoring wells MW-Q, MW-P, KMW03, and GW-1. through GW-5, plus soil gas monitoring wells.

In the case of Pro- $\mathrm{Ag}$, additional groundwater data will be available as part of the Pro- $\mathrm{Ag}$ IM response currently being negotiated with the KDHE. Existing wells that may be included in the Pro-Ag IM monitoring program are (Figure 4) MW-O, KMW01, MW-2, MW-F, MW-I, and MW-G. As part of the IM, Pro-Ag may also be installing some new wells.

On behalf of the CCC/USDA, Argonne will sample the wells according to the approved lowflow procedure dated February 2, 2009. Argonne will also follow the procedures for preservation, shipment, and analysis of samples described in Sections 6.2 and 6.3 of Argonne's Master Work Plan for investigations in Kansas. Pro-Ag will use the same low-flow sampling protocol.

The CCC/USDA-Argonne will report the results of the CCC/USDA sitewide monitoring in 2009 and beyond within 90 days of the sampling. The sitewide monitoring report will include the elements in Section 3.0 of policy BER-RS-036, except that full reporting of items specific to monitoring of the CCC/USDA remediation system at Agra will occur separately, as described in the approved Interim Measure Work Plan/Design for the CCC/USDA remediation project.

The Pro-Ag Co-op will report the results of its sitewide monitoring in 2010 and beyond within 90 days of the sampling. The sitewide monitoring report will include the elements in Section 3.0 of policy BER-RS-036, except that full reporting of items specific to monitoring for the Pro- $\mathrm{Ag}$ IM will occur separately, as approved for that project.

The CCC/USDA-Argonne monitoring will be subject to all of the quality control provisions in the approved Master Work Plan for investigations in Kansas. In addition to the controls on sample collection and analysis at the Applied Geosciences and Environmental Management Laboratory at Argonne, $10 \%$ of the samples will be subjected to verification analysis by Contract Laboratory Program procedures at a second laboratory.

The Pro-Ag sitewide monitoring will be subject to the quality control provisions approved for the Pro-Ag IM project. 
This plan has been developed by the CCC/USDA in coordination with Pro-Ag. The CCC/USDA and Pro-Ag agree to implement the plan as written, subject to any revisions negotiated between the KDHE, the CCC/USDA, and Pro-Ag.

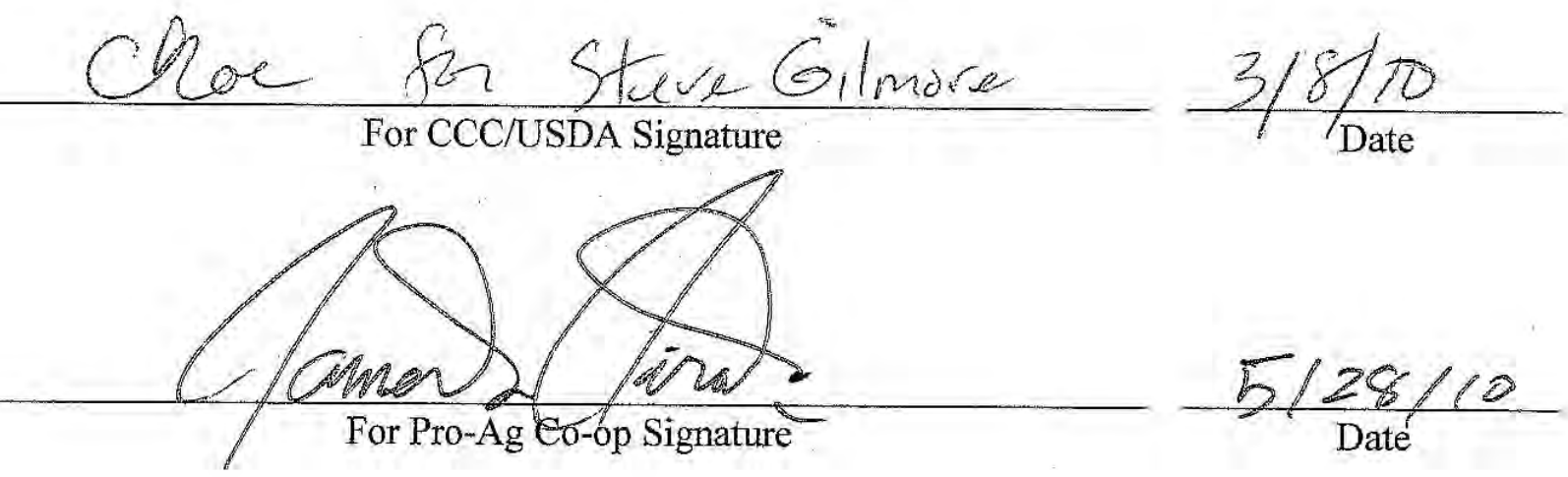




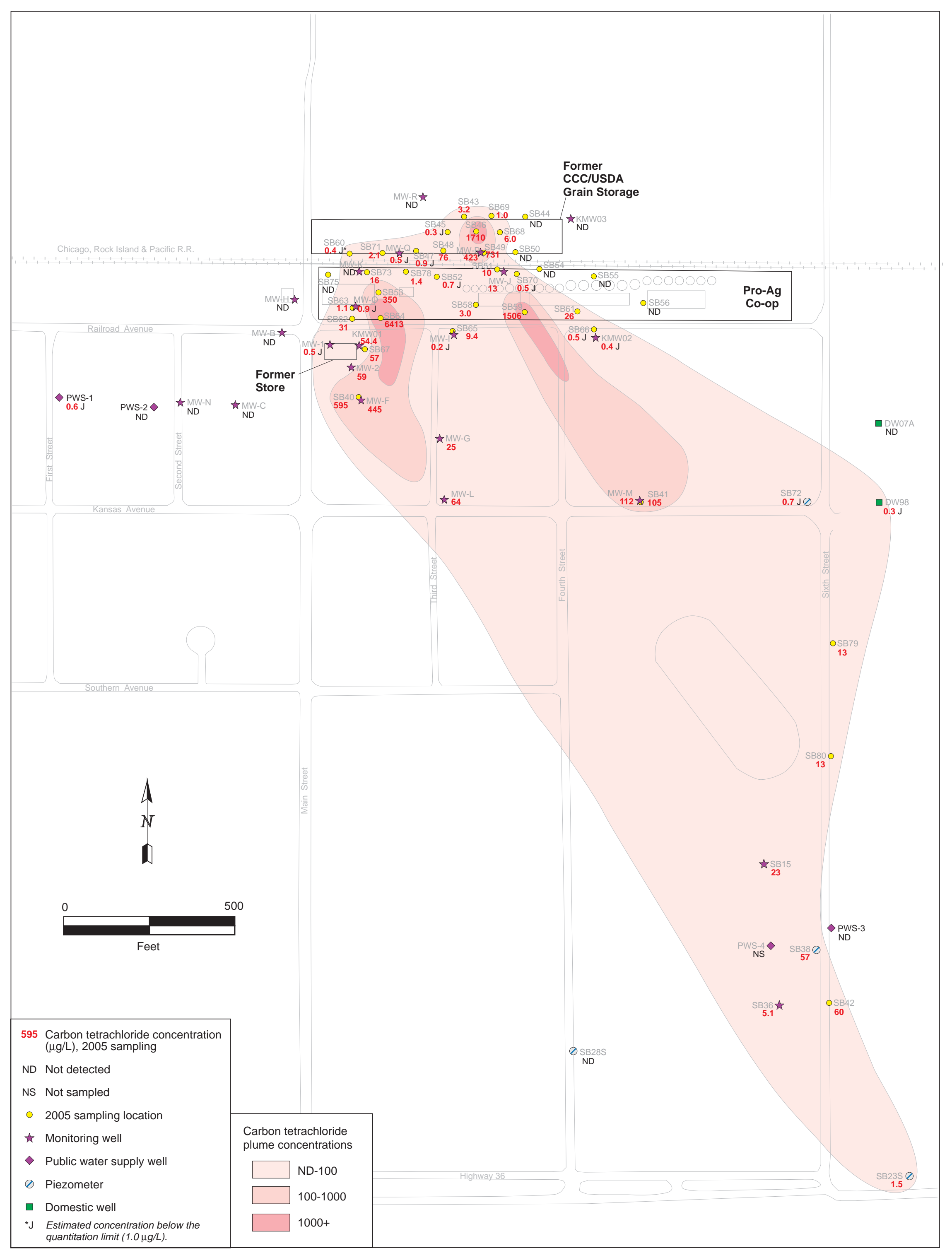

FIGURE 1 Results of the 2005 investigation at Agra, with interpreted plume configuration and soil source areas. 


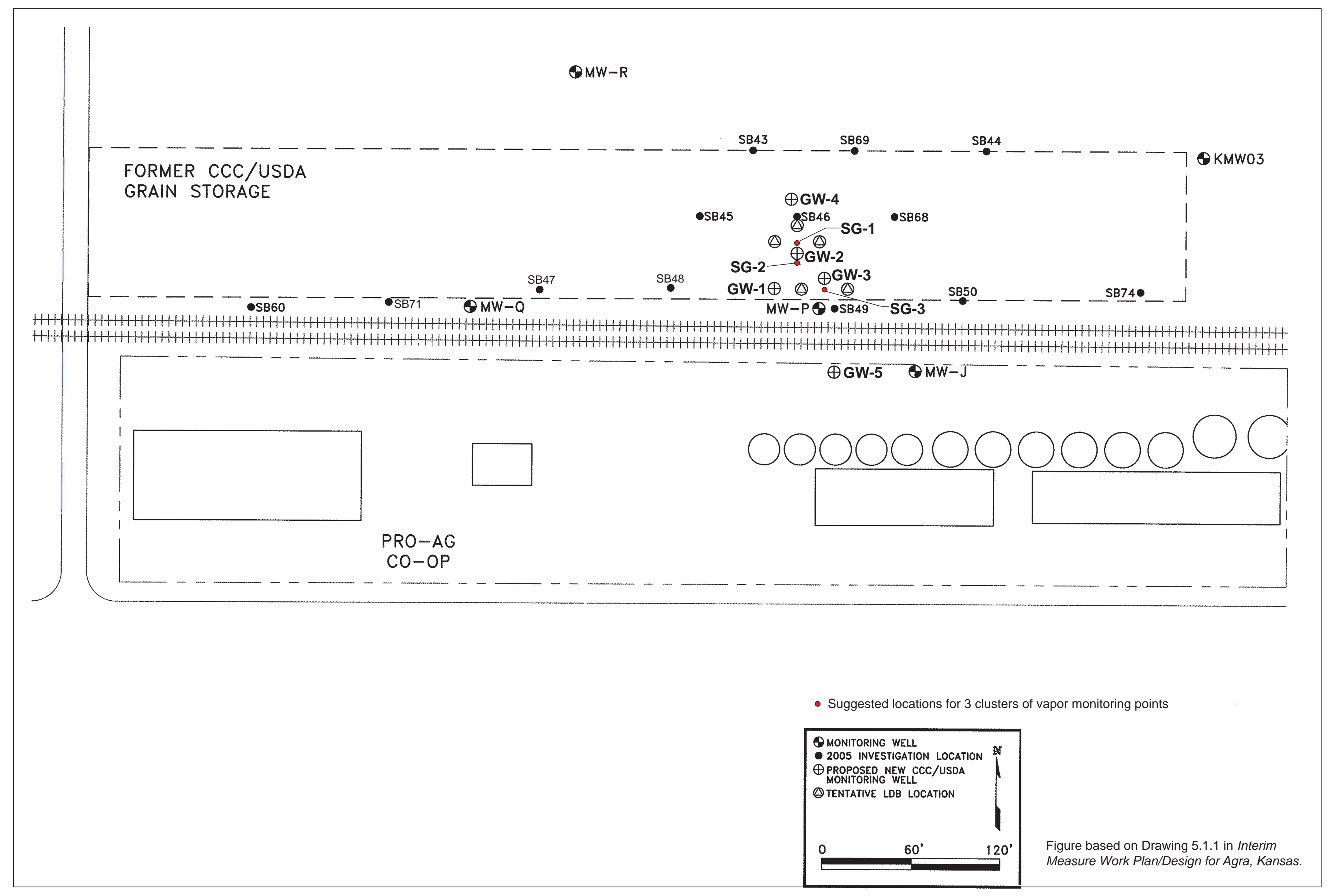




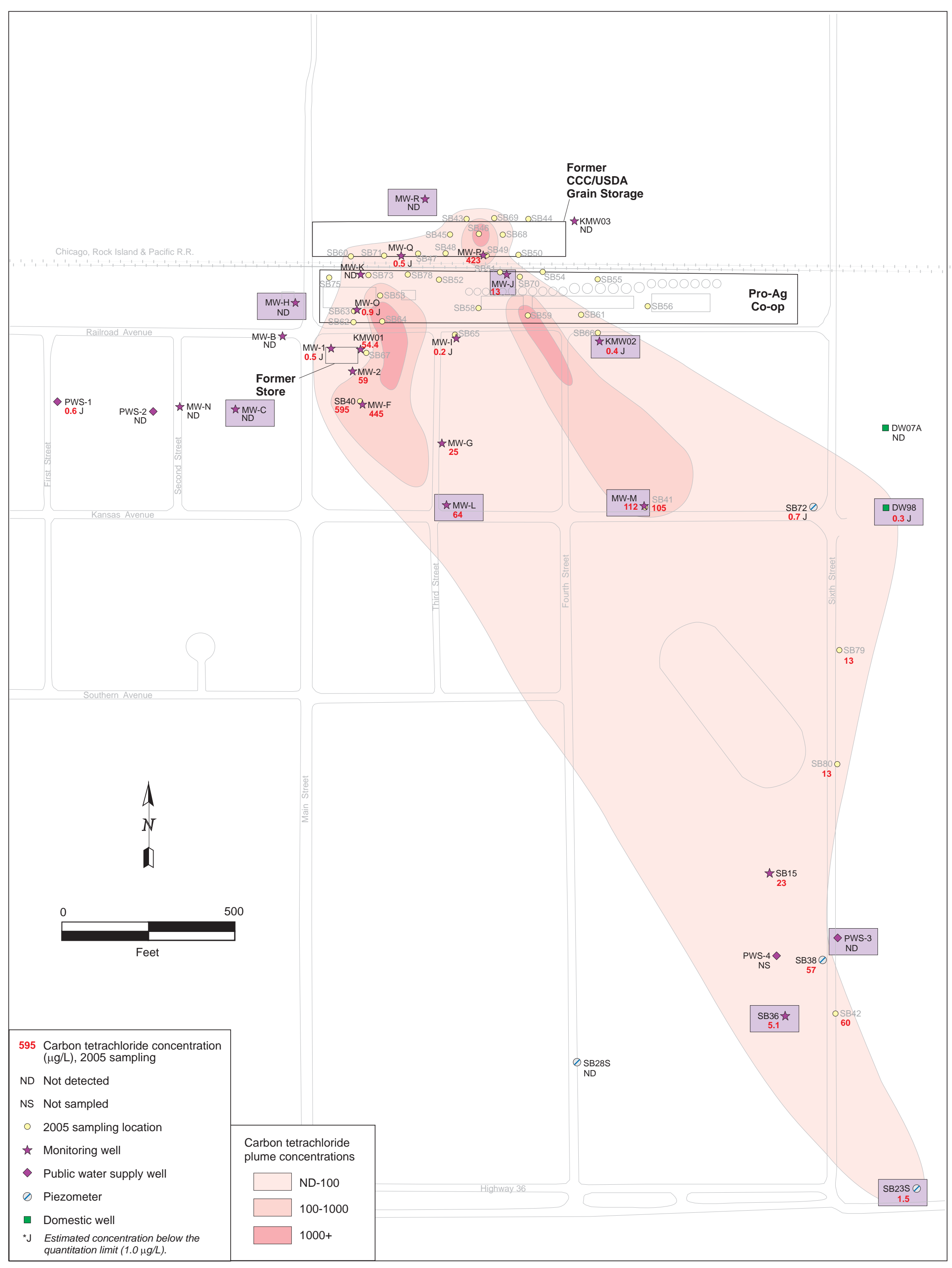

FIGURE 3 Proposed locations (purple box) for yearly monitoring. 


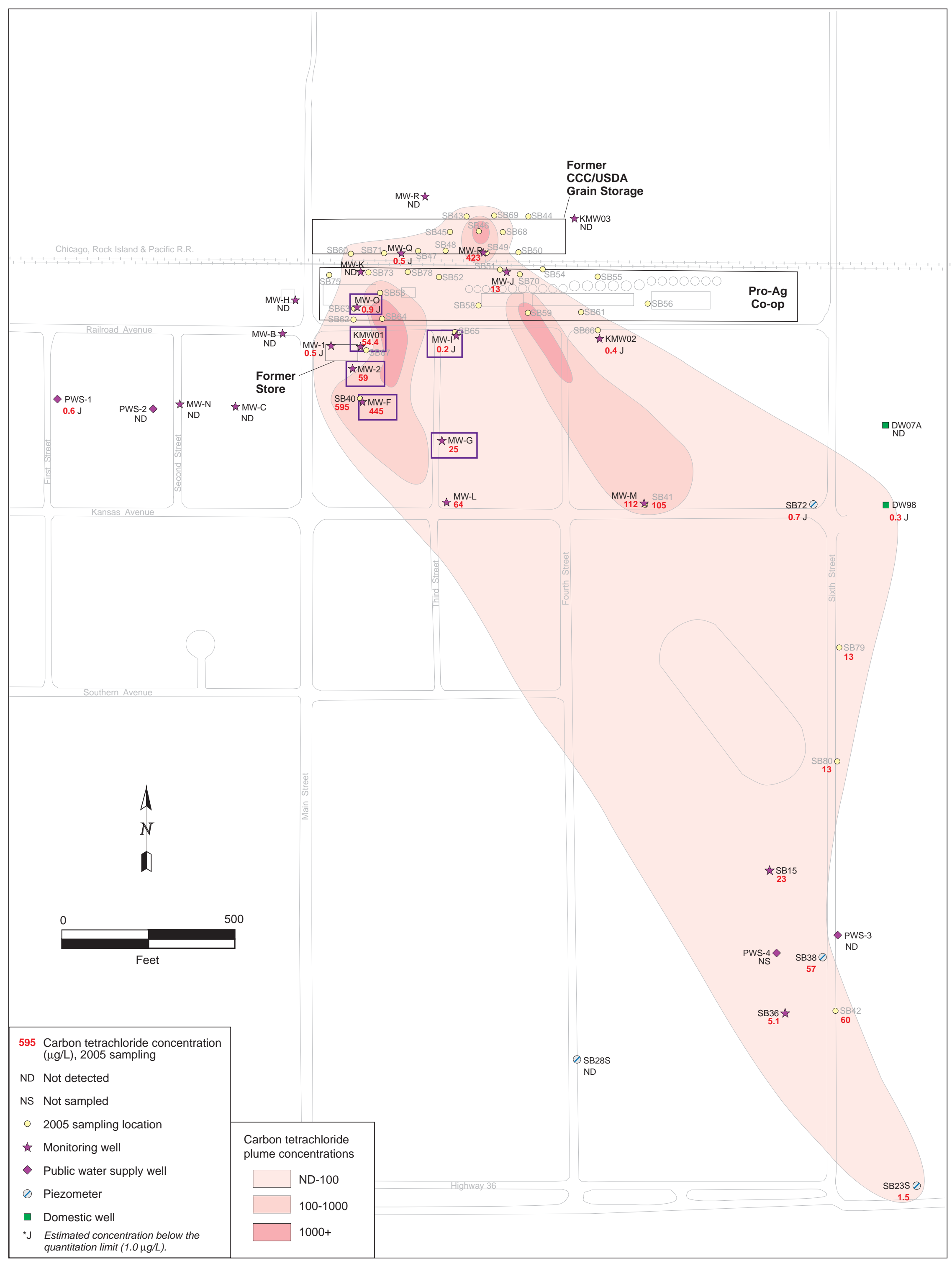

FIGURE 4 Anticipated locations (purple outline) of Pro-Ag IM monitoring. 


\section{Appendix B:}

Sequence of Activities during the May-June 2009 Sitewide Monitoring Event and Field Measurements on Groundwater Samples 
TABLE B.1 Sequence of sitewide monitoring activities at Agra in May-June 2009.

\begin{tabular}{|c|c|c|c|c|c|c|c|}
\hline $\begin{array}{l}\text { Sample } \\
\text { Date }\end{array}$ & Time & $\begin{array}{l}\text { Sample } \\
\text { Location }\end{array}$ & $\begin{array}{l}\text { Depth } \\
\text { (ft BGL) }\end{array}$ & Sample & $\begin{array}{l}\text { Chain of } \\
\text { Custody }\end{array}$ & $\begin{array}{l}\text { Shipping } \\
\text { Date }\end{array}$ & Sample Description \\
\hline $5 / 20 / 09$ & $10: 13$ & GW-5 & $43-53$ & AGGW5-W-17925 & 4396 & 5/21/09 & $\begin{array}{l}\text { South of railroad track. Depth to water }=39.05 \mathrm{ft} \text { on May18. } \\
\text { Purged dry with Waterra pump on May } 18 \text { and May } 19 \text { to } \\
\text { develop. Purged dry again morning of May } 20 . \text { Sampled with } \\
\text { bailer in the afternoon after water level returned to } 39.08 \mathrm{ft} .\end{array}$ \\
\hline $5 / 20 / 09$ & 11:09 & GW-3 & $43-53$ & AGGW3-W-17894 & 4396 & $5 / 21 / 09$ & $\begin{array}{l}\text { Between LDB1 and LDB3. Depth to water }=39.0 \mathrm{ft} \text { on May18. } \\
\text { Purged dry with Waterra pump on May } 18 \text { and May } 19 \text { to } \\
\text { develop. Purged dry again morning of May } 20 . \text { Sampled later } \\
\text { in the day with bailer after water level returned to } 39.10 \mathrm{ft} \text {. }\end{array}$ \\
\hline $5 / 20 / 09$ & $12: 53$ & GW-4 & $43-53$ & AGGW4-W-17895 & 4396 & $5 / 21 / 09$ & $\begin{array}{l}\text { North of LDB5. Depth to water }=40.10 \mathrm{ft} \text { on May } 18 \text {. Purged dry } \\
\text { with Waterra pump on May } 18 \text { and May } 19 \text { to develop. Purged } \\
\text { dry again morning of May } 20 . \text { Sampled later in the day with } \\
\text { bailer after water level returned to } 40.12 \mathrm{ft} \text {. }\end{array}$ \\
\hline $5 / 20 / 09$ & $13: 41$ & GW-2 & $43-53$ & AGGW2-W-17806 & 4396 & $5 / 21 / 09$ & $\begin{array}{l}\text { Between LDB2 and LDB5. Depth to water }=39.15 \mathrm{ft} \text { on May18. } \\
\text { Purged dry with Waterra pump on May } 18 \text { and May } 19 \text { to } \\
\text { develop. Purged dry again morning of May } 20 . \text { Sampled later } \\
\text { in the day with bailer after water level returned to } 41.52 \mathrm{ft} \text {. }\end{array}$ \\
\hline $5 / 20 / 09$ & $13: 51$ & GW-2 & $43-53$ & AGGW2-W-17893 & 4396 & 5/21/09 & Replicate of sample AGGW2-W-17806. \\
\hline $5 / 20 / 09$ & $15: 35$ & GW-1 & $43-53$ & AGGW1-W-17896 & 4396 & $5 / 21 / 09$ & $\begin{array}{l}\text { West of LDB2. Depth to water }=38.75 \mathrm{ft} \text { on May } 18 \text {. Purged dry } \\
\text { with Waterra pump on May } 18 \text { and May } 19 \text { to develop. Purged } \\
\text { dry again morning of May } 20 \text {. Sampled later in the day with } \\
\text { bailer after water level returned to } 42.05 \mathrm{ft} \text {. }\end{array}$ \\
\hline $5 / 20 / 09$ & $15: 59$ & QC & - & AGQCBR-W-17926 & 4396 & $5 / 21 / 09$ & $\begin{array}{l}\text { Rinsate of decontaminated sampling bailer after collection of } \\
\text { sample AGGW1-W-17896. }\end{array}$ \\
\hline $5 / 20 / 09$ & 16:03 & QC & - & AGQCTB-W-17807 & 4396 & $5 / 21 / 09$ & $\begin{array}{l}\text { Trip blank sent to the AGEM Laboratory for organic analysis with } \\
\text { water samples listed on COC } 4396 \text {. }\end{array}$ \\
\hline $6 / 15 / 09$ & $15: 47$ & GW-5 & $43-53$ & AGGW5-Jun15-WL & - & - & $\begin{array}{l}\text { Sample not collected. Depth to water from TOC }=39.23 \mathrm{ft} \text {. Depth } \\
\text { of well }=53 \mathrm{ft} \text {. }\end{array}$ \\
\hline $6 / 15 / 09$ & $16: 04$ & GW-1 & $43-53$ & AGGW1-Jun15-WL & - & - & $\begin{array}{l}\text { Sample not collected. Depth to water from TOC }=39.11 \mathrm{ft} \text {. Depth } \\
\text { of well }=53 \mathrm{ft} \text {. }\end{array}$ \\
\hline $6 / 15 / 09$ & $16: 11$ & GW-3 & $43-53$ & AGGW3-Jun15-WL & - & - & $\begin{array}{l}\text { Sample not collected. Depth to water from TOC }=39.51 \mathrm{ft} \text {. Depth } \\
\text { of well }=53 \mathrm{ft} \text {. }\end{array}$ \\
\hline $6 / 15 / 09$ & $16: 26$ & GW-2 & $43-53$ & AGGW2-Jun15-WL & - & - & $\begin{array}{l}\text { Sample not collected. Depth to water from TOC }=38.95 \mathrm{ft} \text {. Depth } \\
\text { of well }=53 \mathrm{ft} \text {. }\end{array}$ \\
\hline $6 / 15 / 09$ & $16: 45$ & MW-H & $43-53$ & AGMWH-W-17944 & 2519 & 6/17/09 & $\begin{array}{l}\text { Depth to water }=42.1 \mathrm{ft} \text {. Depth of } 2 \text {-in. well }=53 \mathrm{ft} \text {. Sample } \\
\text { collected by using low-flow bladder pump after purging of } \\
15 \text { L. Pump intake positioned at } 48 \mathrm{ft} \text {. }\end{array}$ \\
\hline $6 / 15 / 09$ & $16: 46$ & GW-4 & $43-53$ & AGGW4-Jun15-WL & - & - & $\begin{array}{l}\text { Sample not collected. Depth to water from TOC }=39.55 \mathrm{ft} \text {. Depth } \\
\text { of well }=53 \mathrm{ft} \text {. }\end{array}$ \\
\hline
\end{tabular}


TABLE B.1 (Cont.)

\begin{tabular}{|c|c|c|c|c|c|c|c|}
\hline $\begin{array}{l}\text { Sample } \\
\text { Date }\end{array}$ & Time & $\begin{array}{l}\text { Sample } \\
\text { Location }\end{array}$ & $\begin{array}{l}\text { Depth } \\
\text { (ft BGL) }\end{array}$ & Sample & $\begin{array}{l}\text { Chain of } \\
\text { Custody }\end{array}$ & $\begin{array}{l}\text { Shipping } \\
\text { Date }\end{array}$ & Sample Description \\
\hline $6 / 15 / 09$ & $17: 55$ & MW-C & $35-55$ & AGMWC-W-17943 & 2519 & $6 / 17 / 09$ & $\begin{array}{l}\text { Depth to water }=39.0 \mathrm{ft} \text {. Depth of } 2 \text {-in. well }=55 \mathrm{ft} \text {. Sample } \\
\text { collected by using low-flow bladder pump after purging of } \\
6.5 \mathrm{~L} \text {. Pump intake positioned at } 45 \mathrm{ft} \text {. }\end{array}$ \\
\hline $6 / 15 / 09$ & $18: 24$ & MW-R & $\begin{array}{l}44.45- \\
63.95\end{array}$ & AGMWR-W-17950 & 2519 & $6 / 17 / 09$ & $\begin{array}{l}\text { Depth to water }=39.22 \mathrm{ft} \text {. Depth of } 2 \text {-in. well }=63.95 \mathrm{ft} \text {. Sample } \\
\text { collected by using low-flow bladder pump after purging of } 7 \mathrm{~L} \text {. } \\
\text { Pump intake positioned at } 54.20 \mathrm{ft} \text {. }\end{array}$ \\
\hline $6 / 15 / 09$ & $20: 27$ & MW-M & $59-69$ & AGMWM-W-17947 & 2519 & $6 / 17 / 09$ & $\begin{array}{l}\text { Depth to water }=42.8 \mathrm{ft} \text {. Depth of } 2 \text {-in. well }=69 \mathrm{ft} \text {. Sample } \\
\text { collected by using low-flow bladder pump after purging of } 8 \mathrm{~L} \text {. } \\
\text { Pump intake positioned at } 64 \mathrm{ft} \text {. Water was silty. }\end{array}$ \\
\hline $6 / 15 / 09$ & 20:29 & MW-M & $59-69$ & $\begin{array}{l}\text { AGMWMDUP-W- } \\
17955\end{array}$ & 2519 & $6 / 17 / 09$ & Replicate of sample AGMWM-W-17947. \\
\hline $6 / 16 / 09$ & $8: 42$ & MW-L & $70-80$ & AGMWL-W-17946 & 2519 & $6 / 17 / 09$ & $\begin{array}{l}\text { Depth to water }=42.05 \mathrm{ft} \text {. Depth of } 2 \text {-in. well }=75.8 \mathrm{ft} \text {. Sample } \\
\text { collected by using low-flow bladder pump after purging of } 6 \mathrm{~L} \text {. } \\
\text { Pump intake positioned at } 73.8 \mathrm{ft} \text {. Bottom silted in to } 73.8 \mathrm{ft} \\
\text { during purge. }\end{array}$ \\
\hline 6/16/09 & 9:02 & KMW03 & 74-89 & AGKMW3-W-17942 & 2519 & 6/17/09 & $\begin{array}{l}\text { Depth to water }=39.47 \mathrm{ft} \text {. Depth of } 2 \text {-in. well }=89 \mathrm{ft} \text {. Sample } \\
\text { collected by using low-flow bladder pump after purging of } \\
6.5 \mathrm{~L} \text {. Pump intake positioned at } 81.5 \mathrm{ft} \text {. }\end{array}$ \\
\hline $6 / 16 / 09$ & $11: 08$ & KMW02 & $57-97$ & AGKMW2-W-17941 & 2519 & $6 / 17 / 09$ & $\begin{array}{l}\text { Depth to water }=41.8 \mathrm{ft} \text {. Depth of } 2 \text {-in. well }=97 \mathrm{ft} \text {. Sample } \\
\text { collected by using low-flow bladder pump after purging of } 6 \mathrm{~L} \text {. } \\
\text { Pump intake positioned at } 77 \mathrm{ft} \text {. }\end{array}$ \\
\hline $6 / 16 / 09$ & $11: 14$ & QC & - & AGQCIR-W-17957 & 2519 & $6 / 17 / 09$ & $\begin{array}{l}\text { Rinsate of decontaminated sampling line after collection of } \\
\text { sample AGKMW2-W-17941. }\end{array}$ \\
\hline $6 / 16 / 09$ & $11: 26$ & MW-Q & $\begin{array}{l}43.28- \\
62.78\end{array}$ & AGMWQ-W-17949 & 2519 & $6 / 17 / 09$ & $\begin{array}{l}\text { Depth to water }=39.11 \mathrm{ft} \text {. Depth of } 2 \text {-in. well }=62.78 \mathrm{ft} \text {. Sample } \\
\text { collected by using low-flow bladder pump after purging of } 6 \mathrm{~L} \text {. } \\
\text { Pump intake positioned at } 53.03 \mathrm{ft} \text {. }\end{array}$ \\
\hline 6/16/09 & $12: 26$ & MW-J & $56-66$ & AGMWJ-W-17945 & 2519 & 6/17/09 & $\begin{array}{l}\text { Depth to water }=39.45 \mathrm{ft} \text {. Depth of } 2 \text {-in. well }=66 \mathrm{ft} \text {. Sample } \\
\text { collected by using low-flow bladder pump after purging of } \\
9.4 \text { L. Pump intake positioned at } 61 \mathrm{ft} \text {. }\end{array}$ \\
\hline 6/16/09 & $13: 22$ & MW-P & $\begin{array}{l}35.42- \\
54.92\end{array}$ & AGMWP-W-17948 & 2519 & 6/17/09 & $\begin{array}{l}\text { Depth to water }=38.65 \mathrm{ft} \text {. Depth of } 2 \text {-in. well }=54.92 \mathrm{ft} \text {. Sample } \\
\text { collected by using low-flow bladder pump after purging of } 6 \mathrm{~L} \text {. } \\
\text { Pump intake positioned at } 45.78 \mathrm{ft} \text {. }\end{array}$ \\
\hline $6 / 16 / 09$ & $13: 40$ & QC & - & AGQCIR-W-17958 & 2524 & 6/17/09 & $\begin{array}{l}\text { Rinsate of decontaminated sampling line after collection of } \\
\text { sample AGMWP-W-17948. }\end{array}$ \\
\hline 6/16/09 & $14: 15$ & QC & - & AGQCTB-W-17959 & 2519 & 6/17/09 & $\begin{array}{l}\text { Trip blank sent to the AGEM Laboratory for organic analysis with } \\
\text { water samples listed on COCs } 2519 \text { and } 2524 \text {. }\end{array}$ \\
\hline $6 / 16 / 09$ & $15: 16$ & PWS-3 & $65-125$ & AGPWS3-W-17953 & 2524 & $6 / 17 / 09$ & $\begin{array}{l}\text { Allowed well to run for } 5 \text { min prior to field measurement and } \\
\text { sample collection. }\end{array}$ \\
\hline
\end{tabular}


TABLE B.1 (Cont.)

\begin{tabular}{|c|c|c|c|c|c|c|c|}
\hline $\begin{array}{l}\text { Sample } \\
\text { Date }\end{array}$ & Time & $\begin{array}{l}\text { Sample } \\
\text { Location }\end{array}$ & $\begin{array}{c}\text { Depth } \\
\text { (ft BGL) }\end{array}$ & Sample & $\begin{array}{l}\text { Chain of } \\
\text { Custody }\end{array}$ & $\begin{array}{l}\text { Shipping } \\
\text { Date }\end{array}$ & Sample Description \\
\hline $6 / 16 / 09$ & $16: 58$ & SB23S & $49-55$ & AGSB23S-W-17951 & 2524 & $6 / 17 / 09$ & $\begin{array}{l}\text { Depth to water }=30.5 \mathrm{ft} \text {. Depth of } 1 \text { in. well }=55 \mathrm{ft} \text {. Sample } \\
\text { collected with Waterra pump after purging of } 11.32 \mathrm{~L} \text { ( } 3 \text { well } \\
\text { volumes). Pump intake positioned at } 52.00 \mathrm{ft} .\end{array}$ \\
\hline 6/16/09 & $18: 43$ & SB36 & $42.7-62.7$ & AGSB36-W-17952 & 2524 & $6 / 17 / 09$ & $\begin{array}{l}\text { Depth to water }=37.15 \mathrm{ft} \text {. Depth of } 4 \text { in. well }=62.7 \mathrm{ft} \text {. Sample } \\
\text { collected by using low-flow bladder pump after purging of } \\
11.5 \mathrm{~L} \text {. Pump intake positioned at } 52.70 \mathrm{ft} \text {. }\end{array}$ \\
\hline $6 / 16 / 09$ & $18: 44$ & SB36 & $42.7-62.7$ & AGSB36DUP-W-17956 & 2524 & $6 / 17 / 09$ & Replicate of sample AGSB36-W-17952. \\
\hline $6 / 16 / 09$ & $20: 34$ & DW98 & & AGDW98-W-17954 & 2524 & $6 / 17 / 09$ & $\begin{array}{l}\text { Depth to water }=39.4 \mathrm{ft} \text {. Depth of } 8 \text { in. well }=59.5 \mathrm{ft} \text {. Sample } \\
\text { collected by using low-flow bladder pump after purging of } \\
26.5 \mathrm{~L} \text {. Pump intake positioned at } 53 \mathrm{ft} \text {. }\end{array}$ \\
\hline
\end{tabular}
$26.5 \mathrm{~L}$. Pump intake positioned at $53 \mathrm{ft}$ 
TABLE B.2 Field measurements made during sitewide monitoring in May-June 2009.

\begin{tabular}{|c|c|c|c|c|c|c|c|c|}
\hline Location & Sample & $\begin{array}{l}\text { Sampling } \\
\text { Date }\end{array}$ & $\begin{array}{l}\text { Depth to Water } \\
\left(\text { (ft TOC) }{ }^{\mathrm{a}}\right.\end{array}$ & $\begin{array}{l}\text { Temperature } \\
\qquad\left({ }^{\circ} \mathrm{C}\right)\end{array}$ & $\mathrm{pH}$ & $\begin{array}{l}\text { Conductivity } \\
(\mu \mathrm{S} / \mathrm{cm})\end{array}$ & $\begin{array}{l}\text { Oxygen } \\
\text { (mg/L) }\end{array}$ & $\begin{array}{l}\text { Potential } \\
\text { (mV) }\end{array}$ \\
\hline GW-1 & AGGW1-W-17896 & $5 / 20 / 09$ & 38.75 & 16.6 & 7.31 & 1570 & 9.54 & 200 \\
\hline GW-2 & AGGW2-W-17806 & $5 / 20 / 09$ & 39.15 & 17.5 & 7.31 & 1313 & 9.81 & 195 \\
\hline GW-3 & AGGW3-W-17894 & $5 / 20 / 09$ & 39.00 & 16.8 & 7.31 & 1205 & 9.85 & 207 \\
\hline GW-4 & AGGW4-W-17895 & $5 / 20 / 09$ & 40.10 & 17.0 & 7.25 & 995 & 10.06 & 194 \\
\hline GW-5 & AGGW5-W-17925 & $5 / 20 / 09$ & 39.05 & 16.2 & 7.11 & 1778 & 9.28 & 210 \\
\hline GW-1 & Not sampled & 6/15/09 & 39.11 & - & - & - & - & - \\
\hline GW-2 & Not sampled & $6 / 15 / 09$ & 38.95 & - & - & - & - & - \\
\hline GW-3 & Not sampled & 6/15/09 & 39.51 & - & - & - & - & - \\
\hline GW-4 & Not sampled & 6/15/09 & 39.55 & - & - & - & - & - \\
\hline GW-5 & Not sampled & $6 / 15 / 09$ & 39.23 & - & - & - & - & - \\
\hline KMW02 & AGKMW2-W-17941 & 6/16/09 & 41.80 & 19.3 & 6.96 & 1144 & 8.26 & 143 \\
\hline KMW03 & AGKMW3-W-17942 & 6/16/09 & 39.47 & 15.1 & 7.13 & 785 & 5.93 & 229 \\
\hline MW-C & AGMWC-W-17943 & $6 / 15 / 09$ & 39.00 & 18.1 & 7.00 & 1925 & 8.39 & 87 \\
\hline MW-H & AGMWH-W-17944 & $6 / 15 / 09$ & 42.10 & 16.6 & 7.02 & 1802 & 6.05 & 49 \\
\hline MW-J & AGMWJ-W-17945 & $6 / 16 / 09$ & 39.45 & 15.7 & 7.04 & 1052 & 8.25 & 127 \\
\hline MW-L & AGMWL-W-17946 & $6 / 16 / 09$ & 42.05 & 15.3 & 6.92 & 1133 & 3.51 & 212 \\
\hline MW-M & AGMWM-W-17947 & $6 / 15 / 09$ & 42.80 & 15.9 & 6.41 & 898 & 6.35 & 135 \\
\hline MW-P & AGMWP-W-17948 & $6 / 16 / 09$ & 38.65 & 17.3 & 7.13 & 1261 & 7.73 & 121 \\
\hline MW-Q & AGMWQ-W-17949 & 6/16/09 & 39.11 & 17.9 & 7.20 & 750 & 6.31 & 170 \\
\hline MW-R & AGMWR-W-17950 & $6 / 15 / 09$ & 39.22 & 17.1 & 7.11 & 806 & 5.70 & 188 \\
\hline PWS-3 & AGPWS3-W-17953 & 6/16/09 & - & 15.2 & 7.23 & 861 & - & - \\
\hline SB23S & AGSB23S-W-17951 & $6 / 16 / 09$ & 30.50 & 14.5 & $N R^{b}$ & 892 & 7.35 & - \\
\hline SB36 & AGSB36-W-17952 & $6 / 16 / 09$ & 37.15 & 16.7 & 6.20 & 975 & 8.01 & 111 \\
\hline DW98 & AGDW98-W-17954 & $6 / 16 / 09$ & 39.40 & 14.5 & 6.82 & 1142 & 2.10 & 74 \\
\hline
\end{tabular}

a Depth is measured in feet below the top of the well casing.

b NR, not recorded. 


\section{Appendix C:}

\section{Data from Pace Analytical Services for Wastewater Sample}


Section $B$

Required Project information:

Sectlon $\mathrm{C}$

Company: TCW Construction

\section{Address: $141 M$ Street} Lincoln NE 68508 Emell To: +kamler $Q_{\text {tew canstruction }}$

(402) 4167255$]^{\text {Fax }}$ Requested Due Date/TAT

Involce Information:

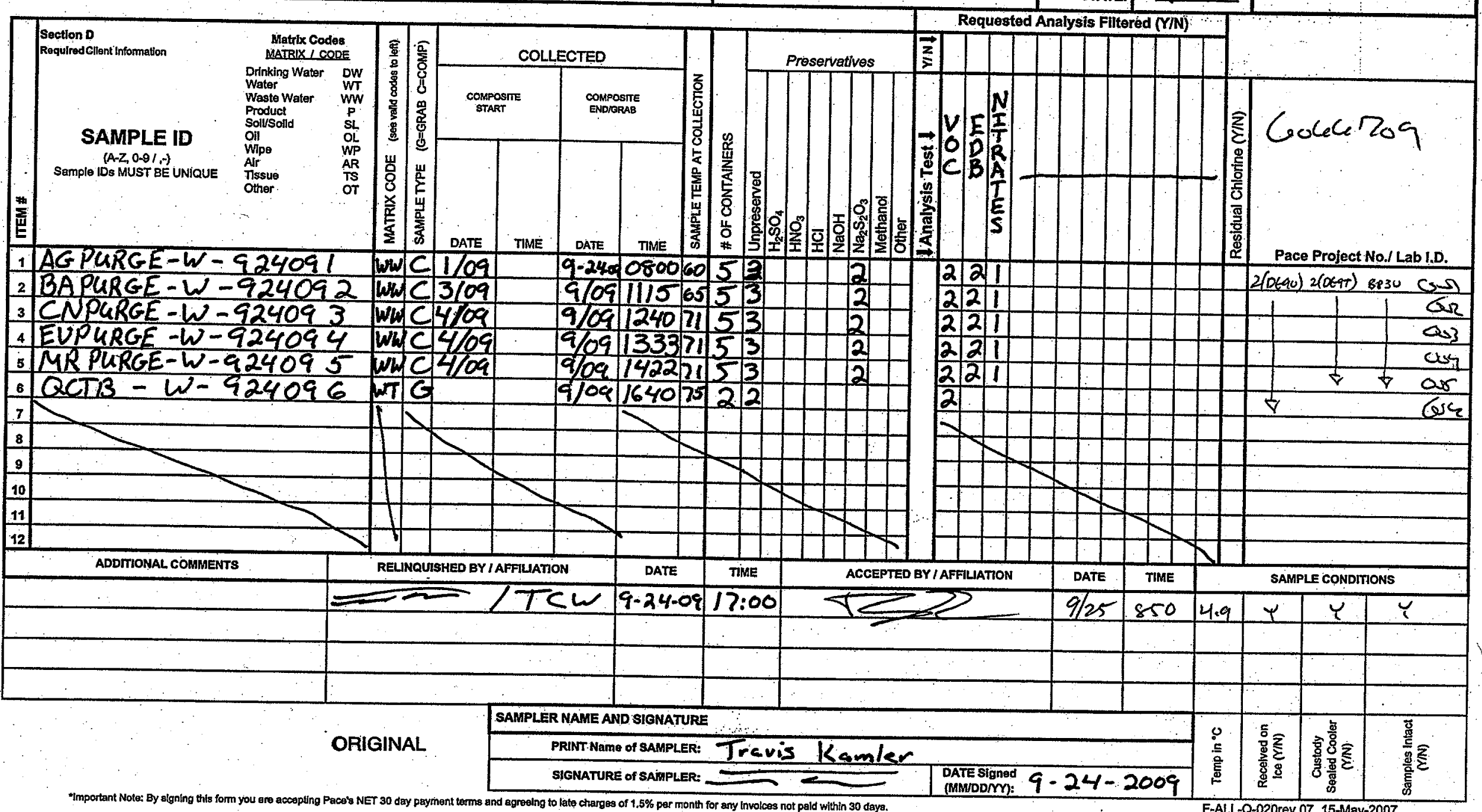

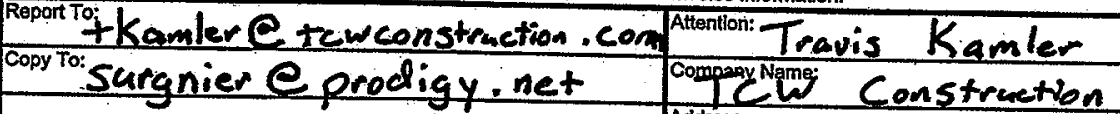
Adgressi $M$ strect Lincoln $N$ Pace Quote
Roference: Projoct Name: Kansas. Waste Water
Project Number: Project Number Pace Proplect Trady Cipson $\Gamma$ NPDES $\mathbb{X}$ GROUND

Pago: 1 of 1 1272137

REGULATORY AGENCY

Q GROUND WATER $\Gamma$ DRINKING WATER Site Location K KCRA $\Gamma$ OTHER STATE: KS

害

\begin{tabular}{|c|c|}
\hline \multicolumn{2}{|c|}{$\begin{array}{l}\text { Matrix Codes } \\
\text { MatRIX / CODE }\end{array}$} \\
\hline $\begin{array}{l}\text { Prinking Wate } \\
\text { Water } \\
\text { Waste Water } \\
\text { Product } \\
\text { Solusolld } \\
\text { Oil } \\
\text { Wipe } \\
\text { Alr } \\
\text { Tlssue } \\
\text { Other. }\end{array}$ & $\begin{array}{l}\text { DW } \\
\text { WT } \\
\text { WW } \\
P \\
\text { SL } \\
\text { OL } \\
\text { WP } \\
\text { AR } \\
\text { TS } \\
\text { OT }\end{array}$ \\
\hline
\end{tabular}

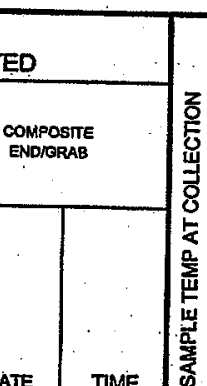

1 AG PARGE-W-G24091

3 CNPGRGE-W-924093

4 EVPURGE $-W-924094$

Q QCTB - W- 924096

(1)

西

\begin{tabular}{|l|}
\hline 10 \\
\hline 11 \\
\hline 12 \\
\hline
\end{tabular}

$\frac{11}{12}$ c 109 . 11505 (5)

9.9711565 5

$9 / 091240715$

(1)

4) 16407522

ORIGINAL 


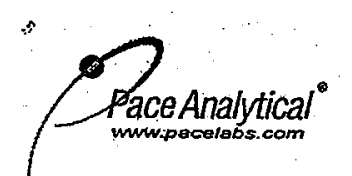

Client Name:

Sample Condition Upon Receipt

Courier: $\square$ Fed Ex $\square$ UPS $\square$ USPS $\square$ Client $\square$ commercial $\square$ Pace other tracking \#: 555876829061

Custody Seal on Cooler/Box Present: $\searrow$ yes

$\square$

Packing Material: $\square$ Bubble Wrap $\square$ Bubble Bags $\square$ None $\square$ other

\begin{tabular}{|c|c|c|c|}
\hline $\begin{array}{l}\text { Thermometer Used } \frac{192 / T-194}{4.9} \\
\text { Cooler Temperature } \frac{1}{\text { Temp should be above freezing to } 6^{\circ} \mathrm{C}}\end{array}$ & $\begin{array}{l}\text { Type of Ice: } 7 \text { et } \\
\text { Biological Tissue i }\end{array}$ & $\begin{array}{l}\text { Blue None } \\
\text { is Frozen: Yes No } \\
\text { Comments: }\end{array}$ & $\begin{array}{l}\square \text { Samples on ice, cooling process has begun } \\
\qquad \begin{array}{c}\text { Date and Initialisof person examining } \\
\text { contents: } 125\end{array}\end{array}$ \\
\hline Chain of Custody Present: & EYes 口no an/A & 1. & \\
\hline Chain of Custody Filled Out: & 飞Yes םno an/A & 2. & \\
\hline Chain of Custody Relinquished: & ǴYes $\square_{N o} \quad \square \mathrm{N} / \mathrm{A}$ & 3. & \\
\hline Sampler Name \& Signature on COC: & EYres $\square_{\text {No }}$ 口N/A & 4. & \\
\hline Samples Arrived within Hold Time: & EYYes 口No, DN/A & 5. & \\
\hline Short Hold Time Analysis ( $<72 \mathrm{hr})$ : & ¿yres DNo DN/A & 6. $\mathrm{NO}_{3}$ & \\
\hline Bush Tum Around Time Requested: & 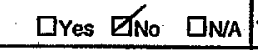 & 7. & \\
\hline Sulficient Volume: & DYes DNo DNA & 8. & \\
\hline $\begin{array}{l}\text { Correct Containers Used: } \\
\text {-Pace Containers Used: }\end{array}$ & 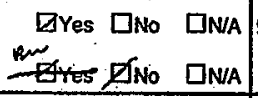 & 9. & \\
\hline Containers Intact: & EYes DNo DNA & 10. & \\
\hline Flltered volume received for Dissolved tests & DYes DNo INA & 11. & $\because$ \\
\hline $\begin{array}{l}\text { Sample Labels match COC: } \\
\text {-Includes date/time/ID/Analysis Matrix: }\end{array}$ & $\begin{array}{l}\text { DYes DNo DNA } \\
\text { WT }\end{array}$ & 12. & LECTES ify \\
\hline $\begin{array}{l}\text { Al containers needing preservation have been checked. } \\
\text { All containers needing preservation are found to be in } \\
\text { complianice with EPA recommendation. }\end{array}$ & 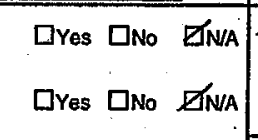 & 13. SiABELS & \\
\hline exceppitions: (NO2 coliform, TOC, ORG, WL-DRO (water) & ZVes 口No & $\begin{array}{l}\text { Initial when } \\
\text { completed. }\end{array}$ & $\begin{array}{l}\text { Lot \# of added } \\
\text { preservative }\end{array}$ \\
\hline Samples checked for dechlorination: & 口Yes 口No EN/Aa & 14. & \\
\hline Headspace in VOA Vials (>6mm): & DYes 口No & 15. & \\
\hline $\begin{array}{l}\text { Trip Blank Present: } \\
\text { Trip Blank Custody Seals Present } \\
\text { Pace Trip Blank Lot \# (if purchased): }\end{array}$ & 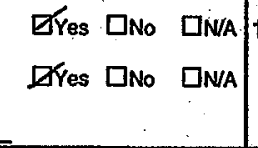 & 16. & \\
\hline
\end{tabular}

Project \#- Codec709 tow

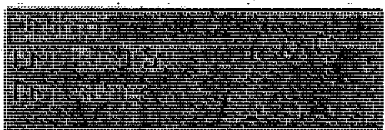

Thermometer Used

4.9

Type of lce: Wet Blue None

has begun

Cooler Temperature . Comments: ate and Initials of person examining

Temp should be above freezing to $6^{\circ}$ EYes पno ana 1.

Chain of Custody Present: שYes पNo DN/A 2.

Chain of Custody Relinquished:

Sampler Name \& Signature on COC: EYes पNo DN/A 4.

Samples Arrived within Hold Time:

Short Hold Time Analysis ( $<72 \mathrm{hr}$ ):

Bush Tum Around Time Requested: 口Yes ZNo DNA 7. Sufficient Volums: DYes DNo DNA 9. -Pace Containers Used: Eres V VNo DN/A

Containers Intact Copy coc to Client? Y $\quad$ (N) Field Data Required? $\mathrm{Y} / \mathrm{N}$

Person Contacted: Travls Kamler Datertime: 9-25.09 Commentis/ Resolution: Per allent- all samples ples collected on $9.2409,40 t$

Project Manager Review: spes $9.28-09$

Date:

Note: Whenever there is a discrepancy affecting North Carolina compllance samples, a capy of this form will be sent to the North Carolina DEHNR Certification Office ( l.e out of hold, incorrect preservative, out of temp, incorrect containers) 


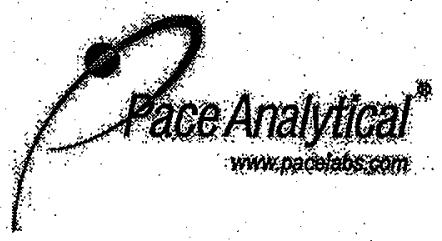

9608 Loiret Blvd.

Lenexa, KS 66219

(913)599-5665

\section{SAMPLE ACKNOWLEDGMENT}

Samples Submitted By: TC̣W Construction lnc Client Project ID:

Client PO\#:
Kansas Waste Water

Credit Card

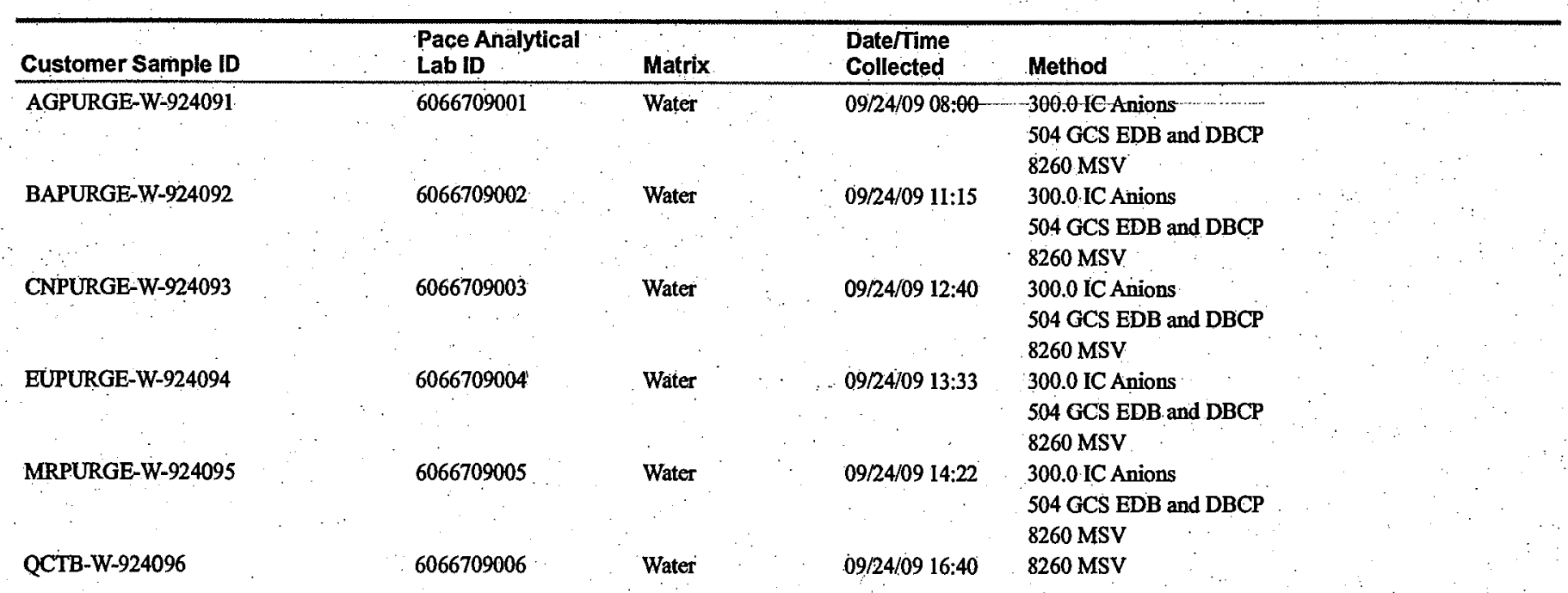

Please contact your project manager if you recognize any discrepancy in this form or have any questions about your project. 
October 13, 2009

Mr. Travis Kamler

TCW Construction Inc

$141 \mathrm{M}$ Street

Lincoln, NE 68508

RE: Project: Kansas Waste Water

Pace Project No.: 6066709

Dear Mr. Kamler:

Enclosed are the analytical results for sample(s) received by the laboratory on September 25, 2009. The results relate only to the samples included in this report. Results reported herein conform to the most current NELAC standards, where applicable, unless otherwise narrated in the body of the report.

If you have any questions concerning this report, please feel free to contact me.

Sincerely,

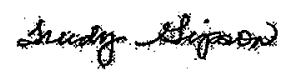

Trudy Gipson

trudy.gipson@pacelabs.com

Project Manager.

Enclosures

cc: Mr. David Surgnier 


\section{CERTIFICATIONS}

Project: Kansas Waste Water

Pace Project No.: 6066709

\section{Kansas Certification IDs}

Washington Certification \#: C2069

Utah Certification \#: 9135995665

Texas Certification \#: T104704407-08-TX

Oregon Certification \#: KS200001

Oklahoma Certification \#: 9205/9935

Nevada Certification \#: KSO00212008A
Louisiana Certification \#: 03055

Kansas/NELAP Certification \#: E-10116

lowa Certification \#: 118

Illinois Certification \#: 001191

Arkansas Certification \#: 05-008-0

A2LA Certification \#: 2456.01

This report shall not be reproduced, except in full, without the written consent of Pace Analytical Services, Inc.

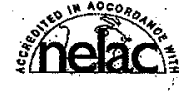




\title{
SAMPLE SUMMARY
}

\author{
Project: Kansas Waste Water \\ Pace Project No.: 6066709
}

\begin{tabular}{llllll}
\hline Lab ID & Sample ID & Matrix & Date Collected & Date Received \\
\hline 6066709001 & AGPURGE-W-924091 & Water & $09 / 24 / 0908: 00$ & $09 / 25 / 0908: 50$ \\
6066709002 & BAPURGE-W-924092 & Water & $09 / 24 / 0911: 15$ & $09 / 25 / 0908: 50$ \\
6066709003 & CNPURGE-W-924093 & Water & $09 / 24 / 0912: 40$ & $09 / 25 / 09.08: 50$ \\
6066709004 & EUPURGE-W-924094 & Water & $09 / 24 / 0913: 33$ & $09 / 25 / 0908: 50$ \\
6066709005 & MRPURGE-W-924095 & Water & $09 / 24 / 0914: 22$ & $09 / 25 / 0908: 50$ \\
6066709006 & QCTB-W-924096 & Water & $09 / 24 / 0916: 40$ & $09 / 25 / 0908: 50$
\end{tabular}




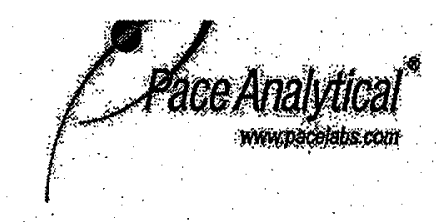

Pace Analytical Services, Inc. 9608 Loiret.Blvd. Lenexa, KS 66219 (913)599-5665

\section{SAMPLE ANALYTE COUNT}

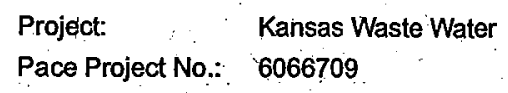

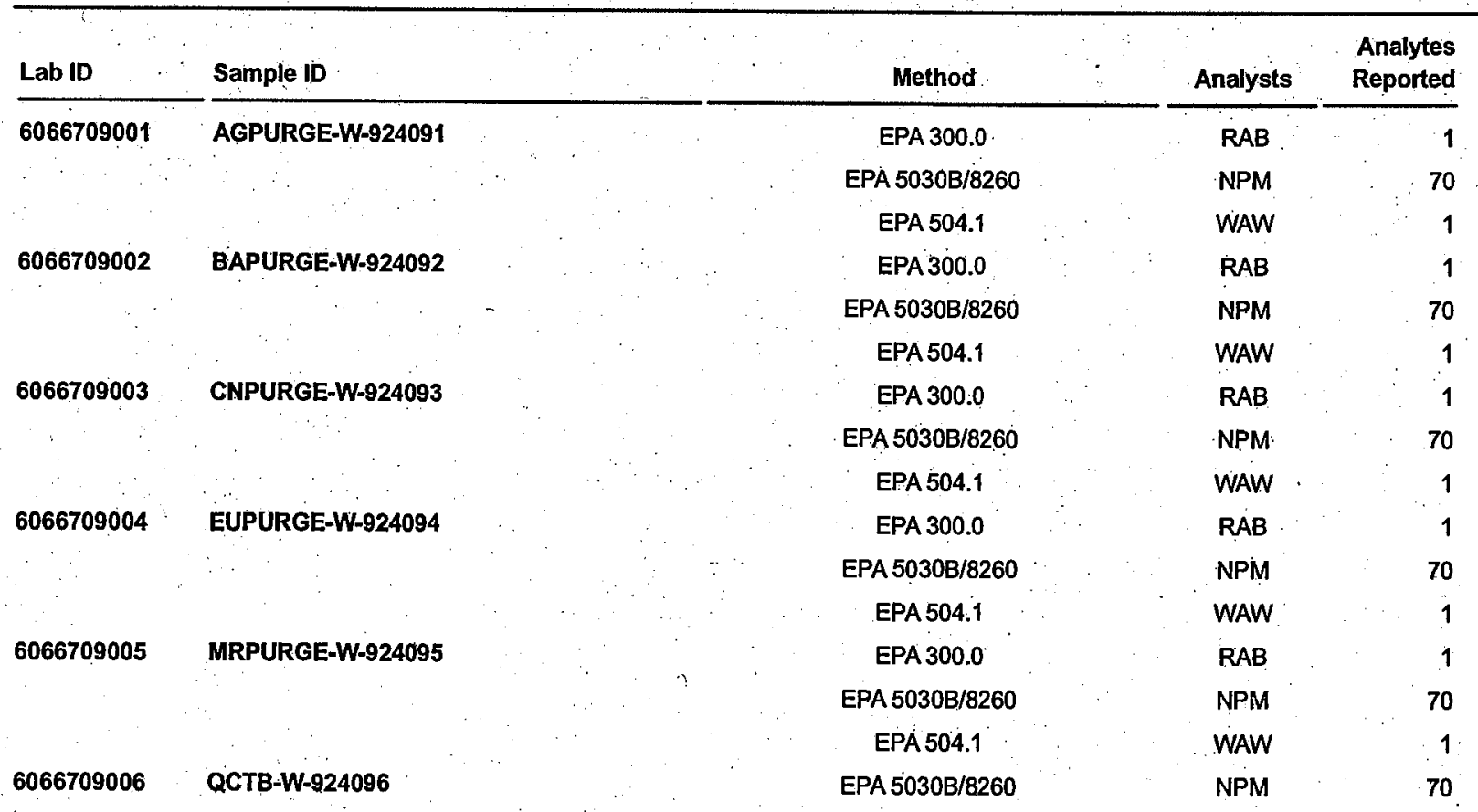




\section{ANALYTICAL RESULTS}

Project: Kansas Waste Water

Pace Project No.: . 6066709

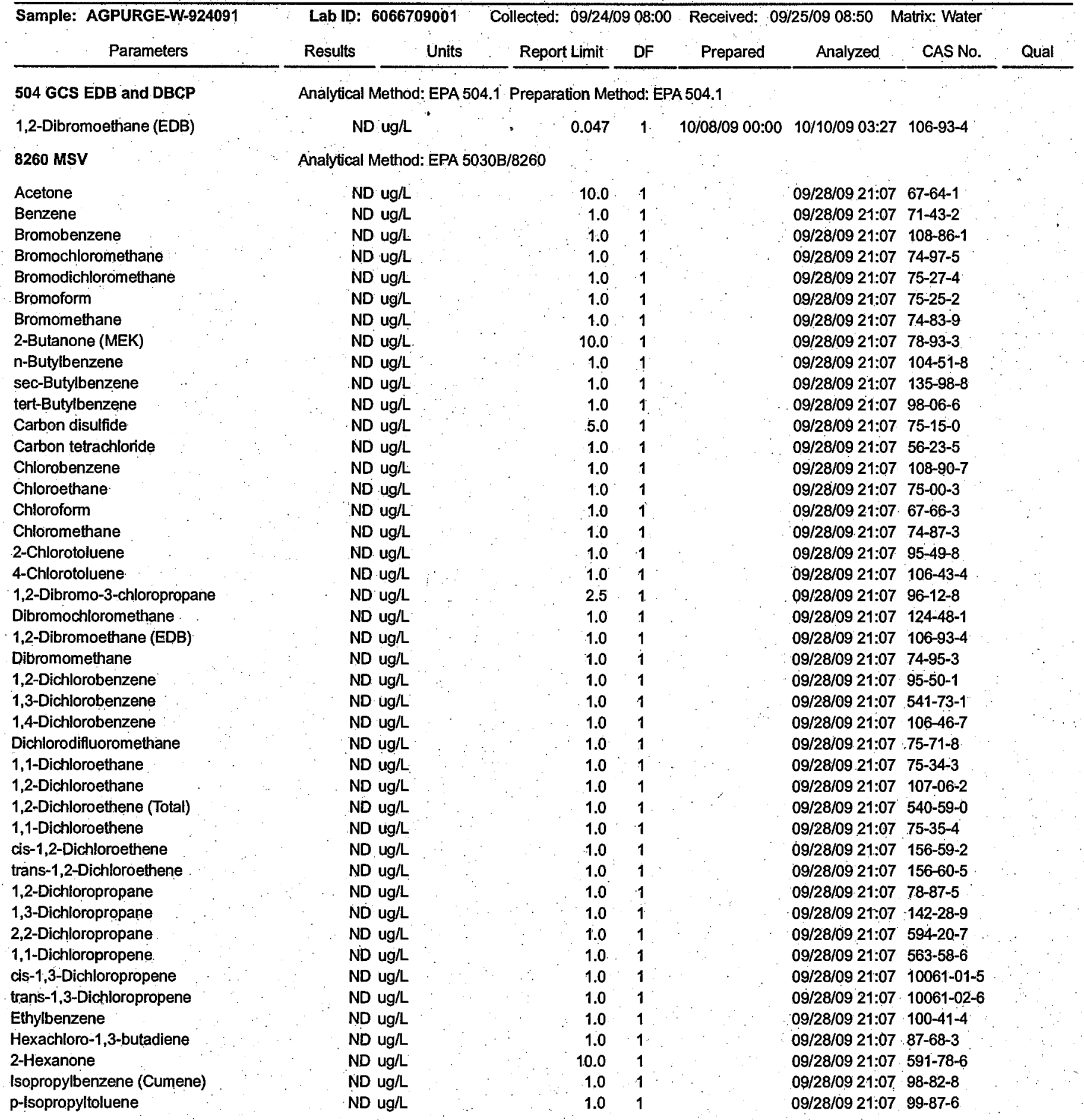

Date: 10/13/2009 03:25 PM 


\section{ANALYTICAL RESULTS}

Project: Kansas Waste Water

Pace Project No.: $\quad 6066709$

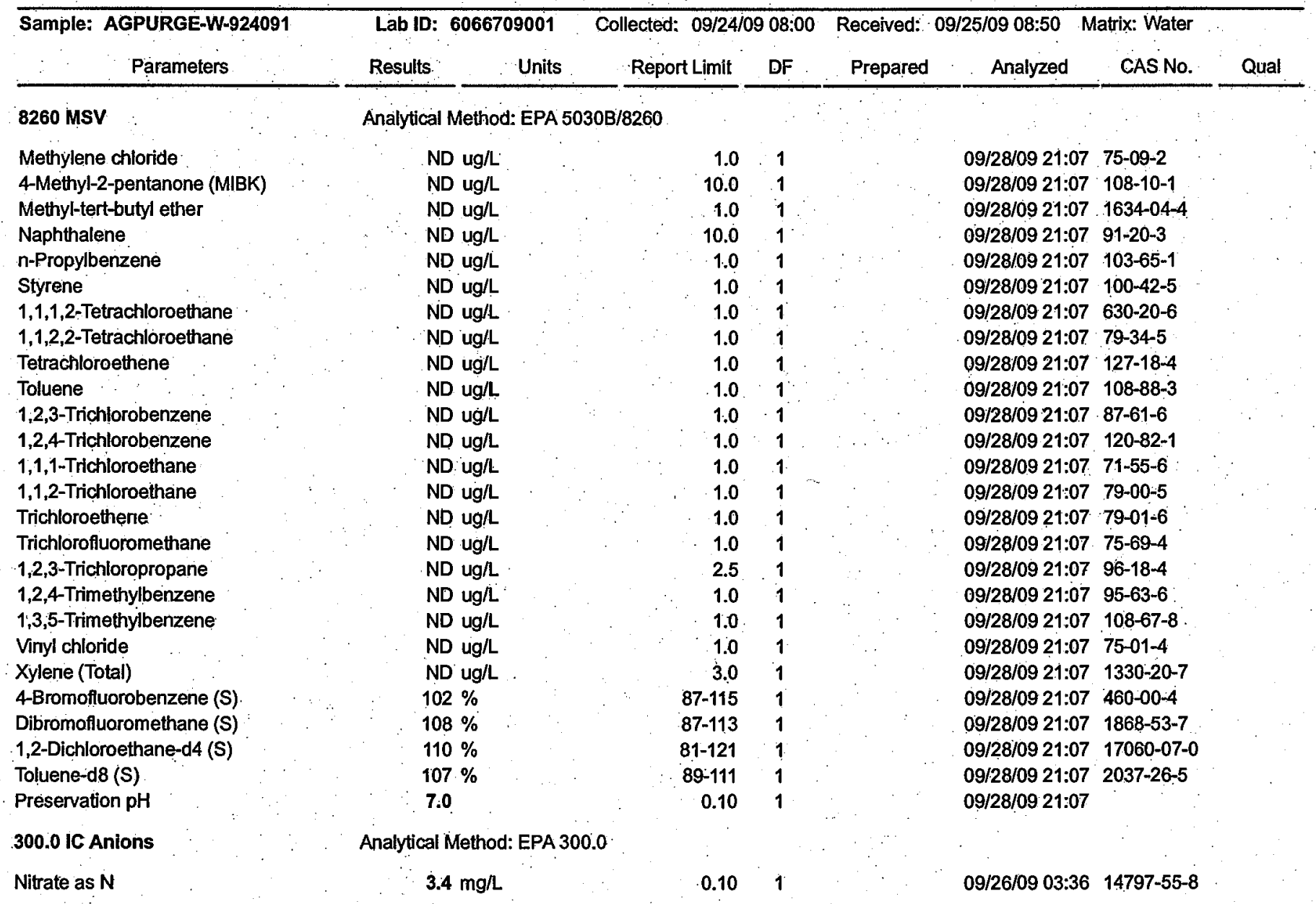




\section{ANALYTICAL RESULTS}

Project:

Kansas Waste Water

Pace Project No.: 6066709

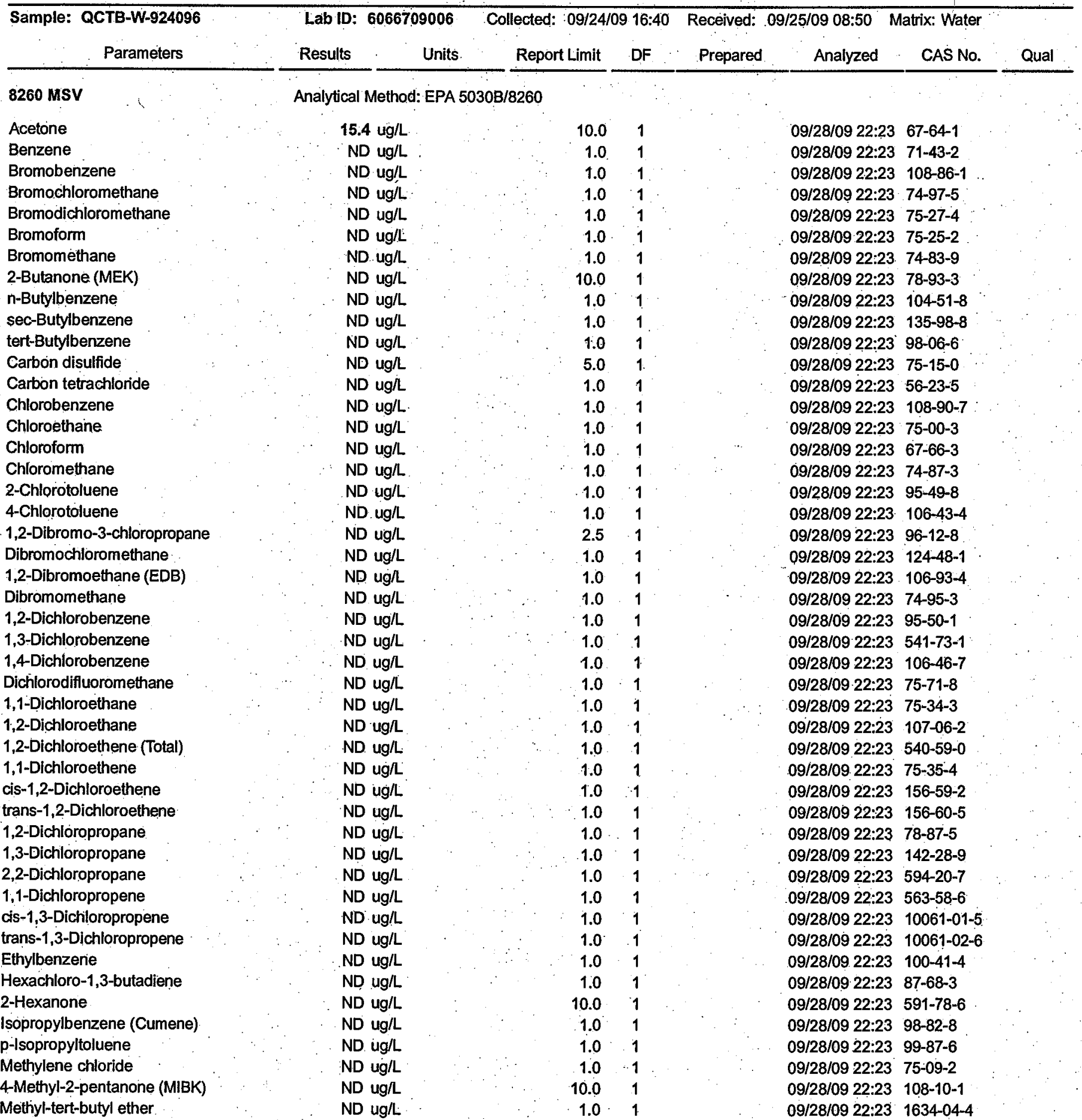

Date: 10/13/2009 03:25 PM

REPORT OF LABORATORY ANALYSIS

This report shall not be reproduced, except in fult,

without the written consent of Pace Analytical Services, Inc.. 


\section{ANALYTICAL RESULTS}

Project:

Kansas Waste Water

Pace Project No:: 6066709

Sample: QCTB-W-924096.

Lab ID: 6066709006

Collected: 09/24/09 16:40 Received: 09/25/09 08:50 Matrix: Water

Parameters

Results

Units

Report Limit

DF

Prepared

Analyzed CAS No.

Qual

\section{MSV}

Naphthalene

n-Prapylbenzene

Styrene

1,1,1,2-Tetrachloroethane

1,1,2,2-Tetrachloroethane

Tetrachloroethene

Toluene

1,2,3-Trichilorobenzerie

1,2,4-Trichlorobenzene

1,1,1-Trichloroethane

1,1,2-Trichloroethane

Trichloroethene

Trichlorofiuoromethane

1,2,3-Trichloropropane

1,2,4-Trimethylbenzene

1,3,5-Trimethylbenzene

Vinyl chloride

Xylene (Total)

4-Bromofluorobenzene (S)

Dibromofluoromethane (S)

1,2-Dichloroethane-d4 (S)

Toluene-d8 (S).

Preservation $\mathrm{pH}$
Analytical Method: EPA 5030B/8260

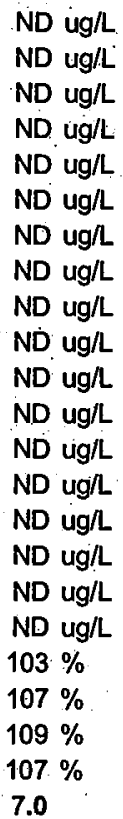

$\begin{array}{rr}10.0 & 1 \\ 1.0 & 1 \\ 1.0 & 1 \\ 1.0 & 1 \\ 1.0 & 1 \\ 1.0 & 1 \\ 1.0 & 1 \\ 1.0 & 1 \\ 1.0 & 1 \\ 1.0 & 1 \\ 1.0 & 1 \\ 1.0 & 1 \\ 1.0 & 1 \\ 2.5 & 1 \\ 1.0 & 1 \\ 1.0 & 1 \\ 1.0 & 1 \\ 3.0 & 1 \\ 87-115 & 1 \\ 87-113 & 1 \\ 81-121 & 1 \\ 89-111 & 1 \\ 0.10 & 1\end{array}$

$09 / 28 / 09$ 22:23 $91-20-3$. 09/28/09 22:23 103-65-1 $09 / 28 / 0922: 23 \quad 100-42-5$ 09/28/09 22:23 630-20-6 09/28/09 22:23 79-34-5 09/28/09 22:23 127-18-4 $09 / 28 / 0922: 23 \quad 108-88-3$ $.09 / 28 / 09$ 22:23 87-61-6 09/28/09 22:23 120-82-1. $09 / 28 / 0922: 23 \quad 71-55-6$ 09/28/09 22:23 79-00-5 09/28/09 22:23 79-01-6 09/28/09 22:23 75-69-4 09/28/09 22:23 96-18-4 09/28/09 22:23 95-63-6 09/28/09 22:23. 108-67-8 09/28/09 22:23 75-01-4 $09 / 28 / 0922: 23 \cdot 1330-20-7$ 09/28/09 22:23 460-00-4 09/28/09 22:23 1868-53-7 09/28/09 22:23. 17060-07-0 09/28/09 22:23 2037-26-5. $09 / 28 / 0922: 23$

This report shall not be reproduced, except in full; without the written consent of Pace Analytical Services, Inc. 


\section{QUALITY CONTROL DATA}

Project: Kansas Waste Water

Pace Project No: 6066709

\begin{tabular}{|c|c|c|c|}
\hline QC Batch: & WETA/10995 & Analysis Method: & EPA 300.0 \\
\hline QC Batch Method: & EPA 300.0 & Analysis Description: & 300.0 lC Anions \\
\hline
\end{tabular}

Associated Lab Samples: $\quad 6066709001,6066709002,6066709003,6066709004,6066709005$

METHOD BLANK: 541949
\begin{tabular}{l} 
Associated Lab Samples: $6066709001,6066709002,6066709003,6066709004,6066709005$ \\
Parameter \\
\hline Nitrate as N
\end{tabular}$\frac{\text { Units }}{\mathrm{mg} / \mathrm{L}} \frac{\text { Result }}{\text { ND }} \frac{\text { Limit }}{0.10} \frac{\text { Analyzed }}{09 / 25 / 0921: 46}$

$\begin{gathered}\text { LABORATORY CONTROL SAMPLE: } 541950 \\ \text { Parameter }\end{gathered} \frac{\text { Units }}{\mathrm{mg} / \mathrm{L}} \frac{\begin{array}{l}\text { Spike } \\ \text { Conc. }\end{array}}{5} \frac{\begin{array}{l}\text { LCS } \\ \text { Result }\end{array}}{4.9} \frac{\text { LCS Rec }}{97} \frac{\text { Limits }}{90-110}$

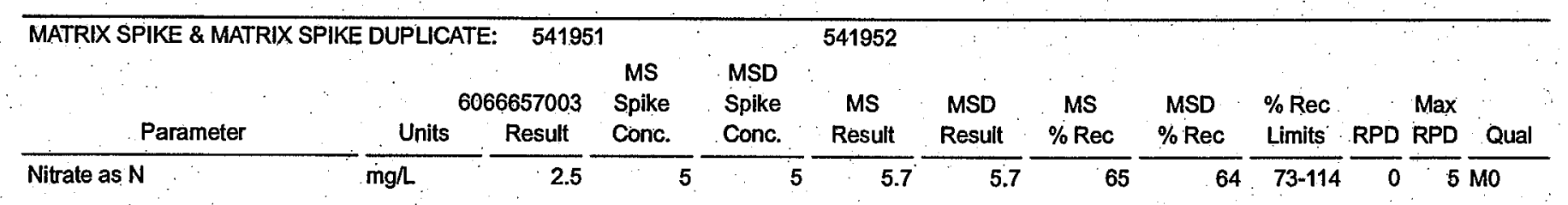

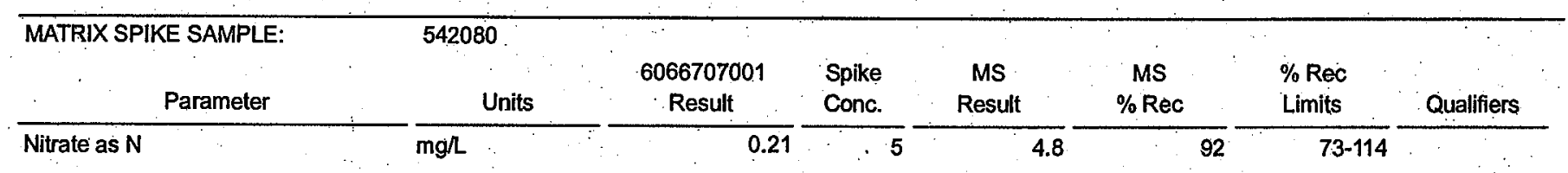




\section{QUALITY CONTROL DATA}

Project: Kansas Waste Water

Pace Project No.: 6066709

\begin{tabular}{llll}
\hline QC Batch: & MSV/23759 & Analysís Method: & EPA 5030B/8260 \\
QC Batch Method: & EPA 5030B/8260 & Analysis Description: & 8260 MSV Water 7 day \\
Associated Lab Samples: $\quad 6066709001,6066709002,6066709003,6066709004,6066709005,6066709006$
\end{tabular}

Associated Lab Samples: $\quad 6066709001,6066709002,6066709003,6066709004,6066709005,6066709006$

METHOD BLANK: $548226 \ldots \ldots$ Matrix: Water

Associated Lab Samples: $\quad 6066709001,6066709002,6066709003,6066709004,6066709005,6066709006$

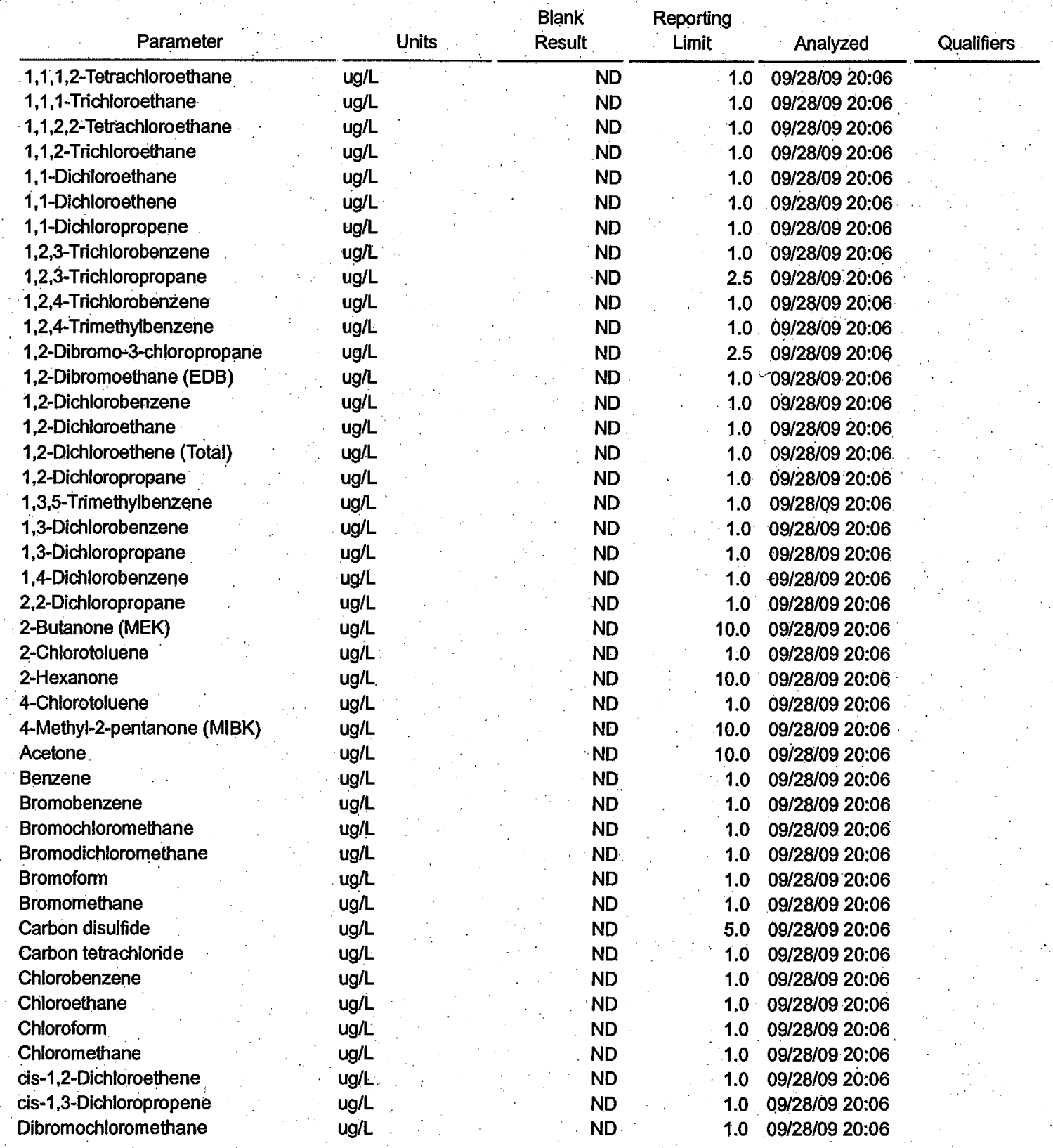

Date: 10/13/2009 03:25 PM

\section{REPORT OF LABORATORY ANALYSIS}

Page 18 of 23

This report shall not be reproduced, except in full,

without the written consent of Pace Analytical Services, Inc..

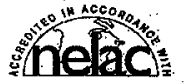




\section{QUALITY CONTROL DATA}

Project: Kansas Waste Water

Pace Project No.: $\quad 6066709$.

METHOD BLANK: $548226 \quad \therefore \quad$ Matrix: Water

Associated Lab Samples: $\quad 6066709001,6066709002,6066709003,6066709004,6066709005,6066709006$

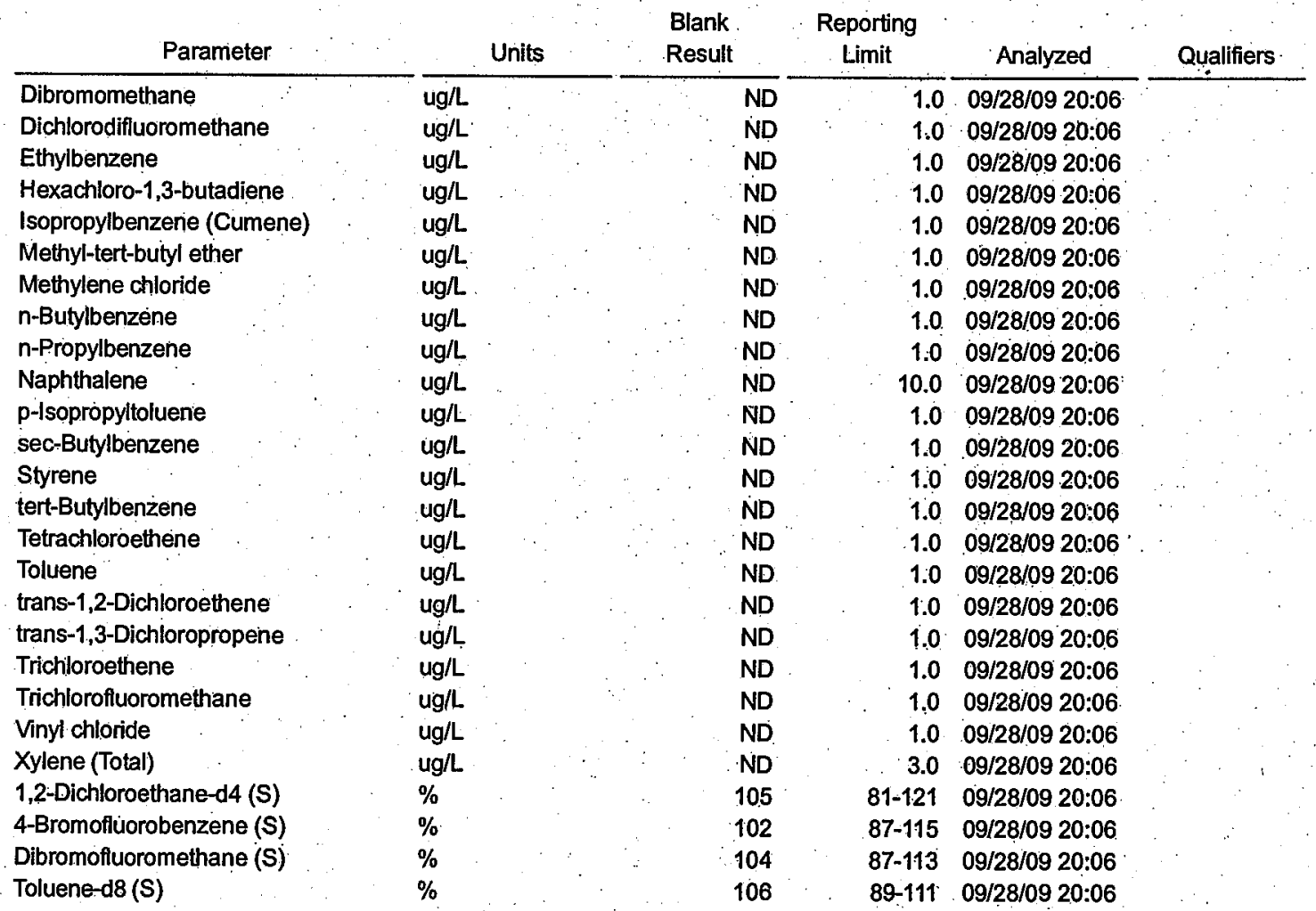

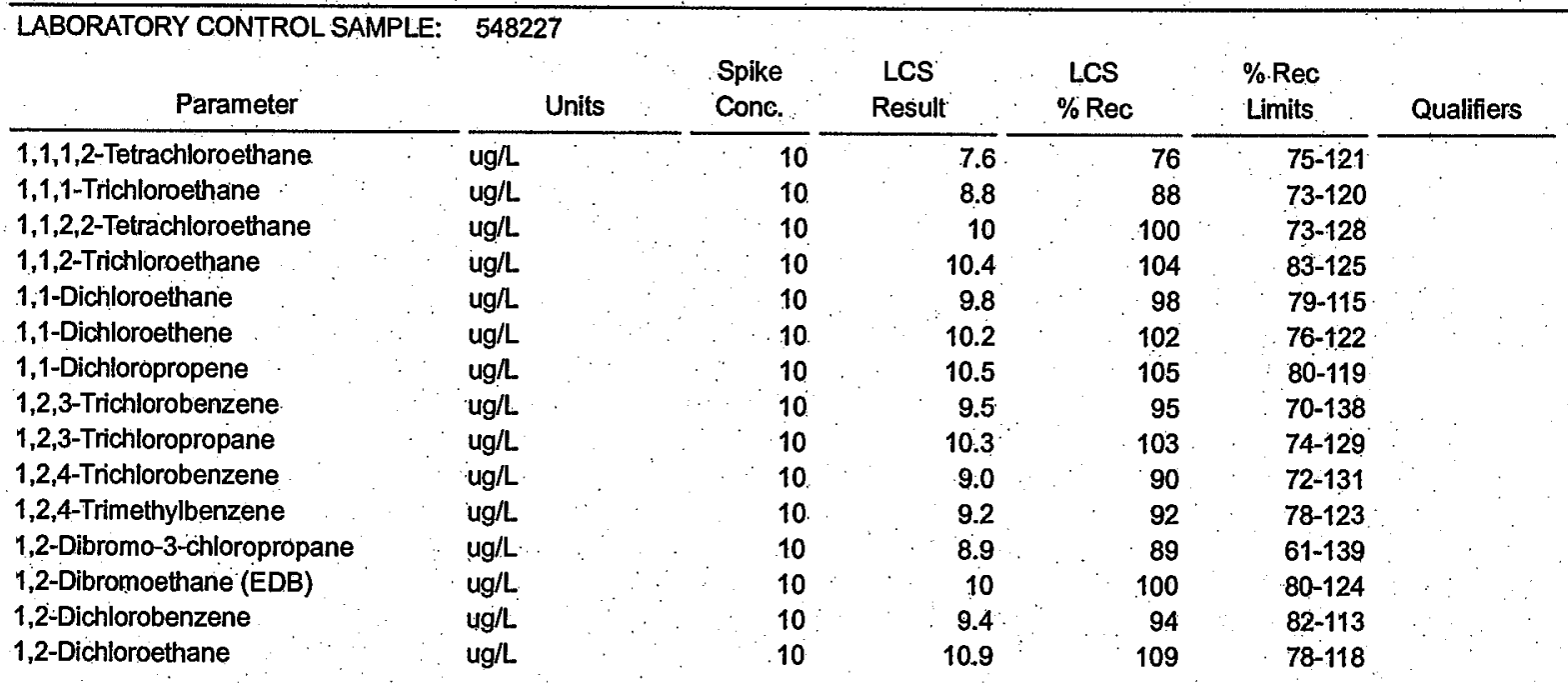

Date: 10/13/2009 03:25 PM

REPORT OF LABORATORY ANALYSIS

This report shall not be reproduced, except in full, without the written consent of Pace Analytical Services, Inc. 


\section{QUALITY CONTROL DATA}

Project: $\quad$ : Kansas Waste Water

Pace Project No.: 6066709

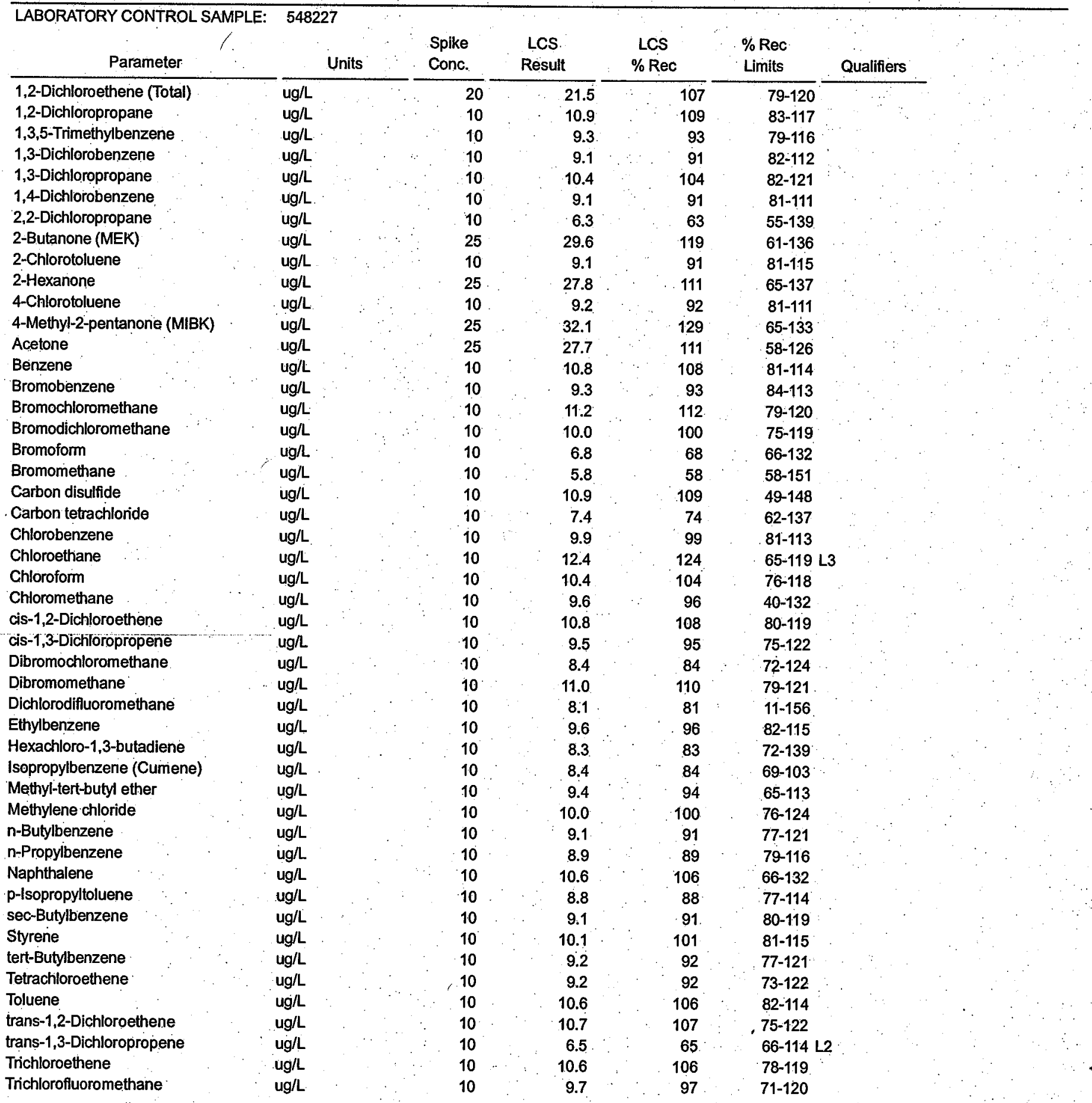

Date: 10/13/2009 03:25 PM 


\section{QUALITY CONTROL DATA}

$\begin{array}{ll}\text { Project: } & \text { Kansas Waste Water } \\ \text { Pace Project No. } & \end{array}$

LABORATORY CONTROL SAMPLE: 548227

\begin{tabular}{|c|c|c|c|c|c|c|}
\hline Parameter & Units & $\begin{array}{l}\text { Spike } \\
\text { Conc. }\end{array}$ & $\begin{array}{l}\text { LCS } \\
\text { Result }\end{array}$ & $\begin{array}{l}\text { LCS } \\
\text { \% Rec }\end{array}$ & $\begin{array}{l}\% \operatorname{Rec} \\
\text { Limits }\end{array}$ & Qualifiers \\
\hline Vinyl chloride & $u g / L^{\prime}$ & 10 & 9.2 & 92 & $67-139$ & \\
\hline Xylene (Total) & ug/L & 30 & 26,9 & 90 & $81-116$ & . \\
\hline 1,2-Dichloroethane-d4 (S) & $\%$ & & & 104 & $81-121$ & \\
\hline 4-Bromofluorobenzene (S) & $\%$ & & & 101 & $87-115$ & \\
\hline Dibromofluoromethane (S) & $\%$ & & & 105 & $87-113$ & \\
\hline Toluene-d8 (\$) & $\%$ & 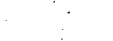 & & 105 & $89-111$ & \\
\hline
\end{tabular}

This report shall not be reproduced, except in full, without the written consent of Pace Analytical Services, Inc. 


\section{QUALITY CONTROL DATA}

Project: Kansas Waste Water

Pace Project No: 6066709

\begin{tabular}{llll}
\hline QC Batch: & OEXT/19948 & Analysis Method: & EPA504.1 \\
QC Batch Method: & EPA 504.1 & Analysis Description: & GCS 504 EDB DBCP
\end{tabular}

Asșociated Lab. Samples: $\quad 6066709001,6066709002,6066709003,6066709004,6066709005$

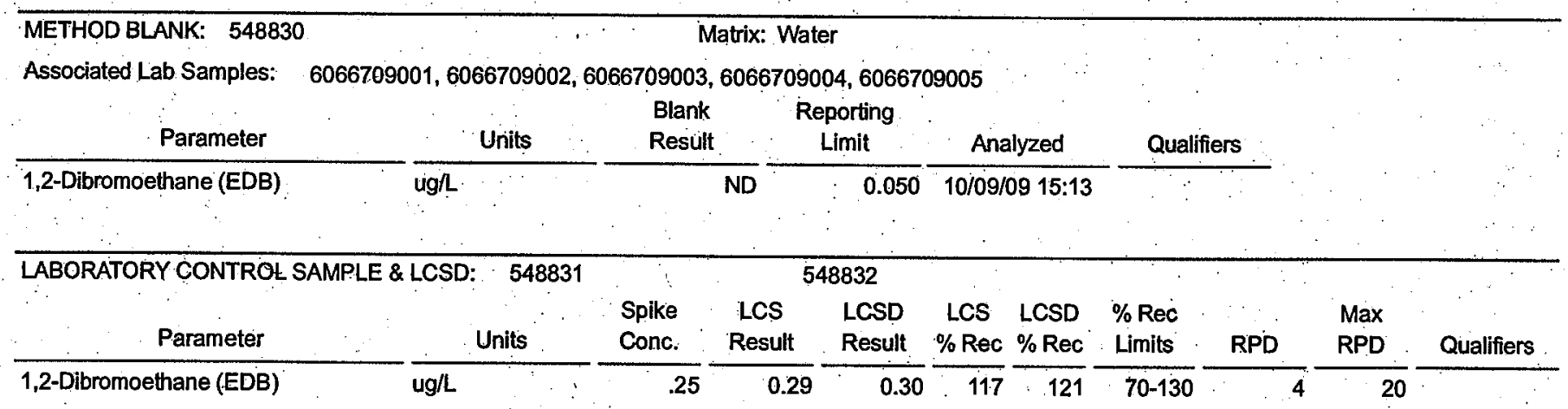




\section{QUALIFIERS}

Project: Kansas Waste Water

Pace Project No.: 6066709

\section{DEFINITIONS}

DF - Dilution Factor, if reported, represents the factor applied to the reported data due to changes in sample preparation, dilution of the sample aliquot, or moisture content.

ND.- Not Detected at or above adjusted reporting limit.

$\checkmark$ - Estimated concentration above the adjusted method detection limit and below the adjusted reporting limit.

MDL-Adjusted Method Detection Limit.

S - Surrogate

1,2-Diphenylhydrazine (8270 listed analyte) decomposes to Azobenzene.

Consistent with EPA guidelines, unrounded data are displayed and have been used to calculate \% recovery and RPD values.

LCS(D) - Laboratory Control Sample (Duplicate)

MS(D) - Matrix Spike (Duplicate)

DUP - Sample Duplicate

RPD - Relative Percent Difference

Pace Analytical is NELAP accredited. Contact your Pace PM for the current list of accredited analytes.

$U$ - Indicates the compound was analyzed for, but not detected.

\section{BATCH QUALIFIERS}

Batch: MSV/23759

[M5] A matrix spike/matrix spike duplicate was not performed for this batch due to insufficient sample volume.

\section{ANALYTE QUALIFIERS}

L2 . Analyte recovery in the laboratory control sample (LCS) was below QC limits. Results for this analyte in associated samples may be biased low:

L3 . Analyte recovery in the laboratory control sample (LCS) exceeded QC limits. Analyte presence below reporting limits in associated samples. Results unaffected by high bias.

Mo Matrix spike recovery and/or matrix spike duplicate recovery was outside laboratory control limits. 


\section{Appendix D:}

\section{Quality Control Data}


TABLE D.1 Quality control results for organic analyses of water samples by the purge-and-trap method at the AGEM Laboratory.

\begin{tabular}{|c|c|c|c|c|c|c|c|c|c|}
\hline \multirow[b]{4}{*}{ Sample } & \multirow{2}{*}{\multicolumn{3}{|c|}{ Recovery of Surrogate Compounds ${ }^{a}(\%)$}} & \multicolumn{6}{|c|}{$\begin{array}{l}\text { Measured Concentration and RPD Value } \\
\text { for Calibration Check Standard }\end{array}$} \\
\hline & & & & \multirow{2}{*}{\multicolumn{2}{|c|}{$\begin{array}{c}\text { Carbon } \\
\text { Tetrachloride }\end{array}$}} & \multirow{2}{*}{\multicolumn{2}{|c|}{ Chloroform }} & \multirow{2}{*}{\multicolumn{2}{|c|}{$\begin{array}{l}\text { Methylene } \\
\text { Chloride }\end{array}$}} \\
\hline & \multirow[b]{2}{*}{ Fluorobenzene } & \multirow[b]{2}{*}{$\begin{array}{c}\text { Bromo- } \\
\text { fluorobenzene }\end{array}$} & \multirow[b]{2}{*}{$\begin{array}{l}\text { 1,4-Dichloro- } \\
\text { benzene-d }_{4}\end{array}$} & & & & & & \\
\hline & & & & $\mathrm{ppb}$ & $\mathrm{RPD}^{\mathrm{b}}$ & $\mathrm{ppb}$ & $\mathrm{RPD}^{\mathrm{b}}$ & $\mathrm{ppb}$ & $\mathrm{RPD}^{\mathrm{b}}$ \\
\hline \multicolumn{10}{|c|}{ SDG 09-5-22, analysis date May 22, 2009} \\
\hline 20-ppb standard & 100 & 100 & 100 & 20.68 & 3.3 & 19.42 & 2.9 & 22.57 & 12.1 \\
\hline Laboratory blank & 120 & 120 & 116 & & & & & & \\
\hline AGGW2-W-17806 & 97 & 104 & 100 & \multicolumn{6}{|c|}{$\begin{array}{l}\text { Outside calibration range for carbon tetrachloride at zero } \\
\text { dilution. }\end{array}$} \\
\hline AGQCTB-W-17807 & 100 & 104 & 106 & & & & & & \\
\hline AGGW5-W-17925 & 98 & 102 & 105 & & & & & & \\
\hline AGQCBR-W-17926 & 91 & 98 & 100 & & & & & & \\
\hline AGGW2-W-17893 & 95 & 104 & 101 & \multirow{2}{*}{\multicolumn{6}{|c|}{$\begin{array}{l}\text { Outside calibration range for carbon tetrachloride at zero } \\
\text { dilution. } \\
\text { Outside calibration range for carbon tetrachloride at zero } \\
\text { dilution. }\end{array}$}} \\
\hline AGGW3-W-17894 & 92 & 109 & 97 & & & & & & \\
\hline AGGW4-W-17895 & 88 & 90 & 92 & & & & & & \\
\hline AGGW1-W-17896 & 87 & 86 & 86 & & & & & & \\
\hline AGGW2-W-17893 & 83 & 93 & 92 & \multirow{3}{*}{\multicolumn{6}{|c|}{$\begin{array}{l}\text { Analysis at dilution factor (DF) } 100 \text { for carbon } \\
\text { Analysis at DF } 100 \text { for carbon tetrachloride. } \\
\text { Analysis at DF } 100 \text { for carbon tetrachloride. }\end{array}$}} \\
\hline AGGW3-W-17894 & 93 & 104 & 106 & & & & & & \\
\hline AGGW2-W-17806 & 89 & 102 & 103 & & & & & & \\
\hline \multicolumn{10}{|c|}{ SDG 09-6-18, analysis date June 18, 2009} \\
\hline 20-ppb standard & 85 & 120 & 111 & 24 & 18.2 & 23.72 & 17.0 & 23.78 & 17.3 \\
\hline Laboratory blank & 100 & 100 & 100 & & & & & & \\
\hline AGKMW2-W-17941 & 108 & 114 & 107 & & & & & & \\
\hline AGKMW3-W-17942 & 108 & 119 & 109 & & & & & & \\
\hline AGMWC-W-17943 & 106 & 116 & 119 & & & & & & \\
\hline AGMWH-W-17944 & 106 & 111 & 107 & & & & & & \\
\hline AGMWJ-W-17945 & 118 & 111 & 113 & & & & & & \\
\hline AGMWL-W-17946 & 113 & 113 & 114 & & & & & & \\
\hline AGMWM-W-17947 & 97 & 91 & 88 & & & & & & \\
\hline
\end{tabular}




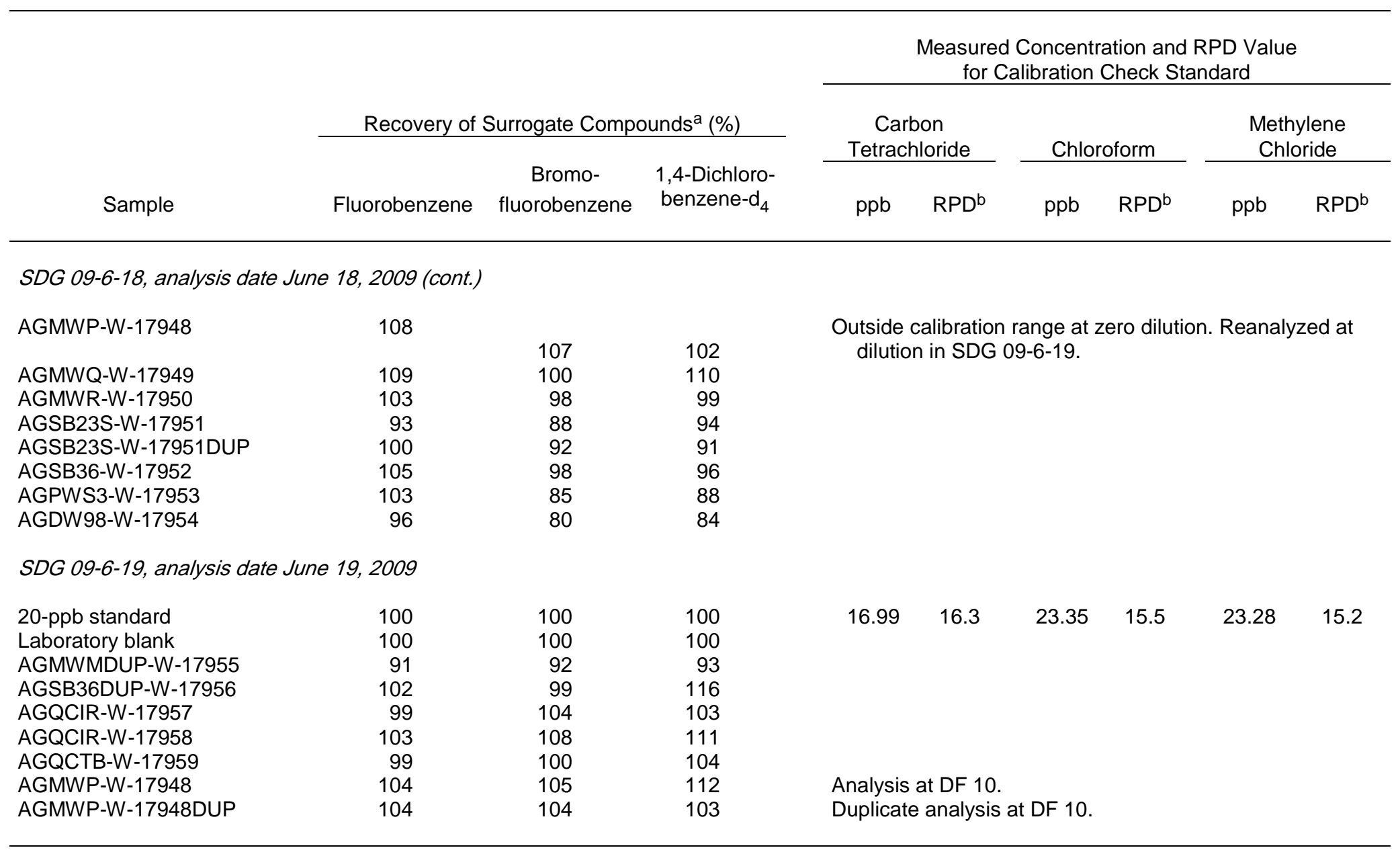

a Quality control range for recovery $=80-120 \%$.

b Quality control range for RPD $= \pm 20 \%$. 
TABLE D.2 Analytical results for quality control samples collected during sitewide monitoring in May-June 2009.

\begin{tabular}{|c|c|c|c|c|c|c|c|c|}
\hline \multirow[b]{2}{*}{ Location } & \multirow[b]{2}{*}{$\begin{array}{l}\text { Depth } \\
\text { (ft BGL) }\end{array}$} & \multirow[b]{2}{*}{$\begin{array}{l}\text { Sampling } \\
\text { Date }\end{array}$} & \multirow[b]{2}{*}{ Sample } & \multirow[b]{2}{*}{ Sample Type } & \multicolumn{4}{|c|}{ Concentration $(\mu \mathrm{g} / \mathrm{L})$} \\
\hline & & & & & $\begin{array}{l}\text { Carbon } \\
\text { Tetrachloride }\end{array}$ & Chloroform & $\begin{array}{l}\text { Methylene } \\
\text { Chloride }\end{array}$ & $\begin{array}{c}1,2- \\
\text { Dichloroethane }\end{array}$ \\
\hline GW-2 & $43-53$ & $5 / 20 / 09$ & $\begin{array}{l}\text { AGGW2-W-17806 } \\
\text { AGGW2-W-17893 }\end{array}$ & $\begin{array}{l}\text { Primary sample } \\
\text { Replicate sample }\end{array}$ & $\begin{array}{l}6090 \\
6393\end{array}$ & $\begin{array}{l}46 \\
42\end{array}$ & $\begin{array}{l}N^{a} \\
N D\end{array}$ & $\begin{array}{l}\text { ND } \\
\text { ND }\end{array}$ \\
\hline MW-M & $59-69$ & 6/15/09 & $\begin{array}{l}\text { AGMWM-W-17947 } \\
\text { AGMWMDUP-W-17955 }\end{array}$ & $\begin{array}{l}\text { Primary sample } \\
\text { Replicate sample }\end{array}$ & $\begin{array}{l}84 \\
80\end{array}$ & $\begin{array}{l}1.5 \\
3.5\end{array}$ & $\begin{array}{l}\text { ND } \\
\text { ND }\end{array}$ & $\begin{array}{l}\text { ND } \\
\text { ND }\end{array}$ \\
\hline MW-P & $\begin{array}{l}35.42- \\
54.92\end{array}$ & 6/16/09 & $\begin{array}{l}\text { AGMWP-W-17948 } \\
\text { AGMWP-W-17948DUP }\end{array}$ & $\begin{array}{l}\text { Primary sample } \\
\text { Duplicate analysis }\end{array}$ & $\begin{array}{l}260 \\
249\end{array}$ & $\begin{array}{l}11 \\
11\end{array}$ & $\begin{array}{l}\text { ND } \\
\text { ND }\end{array}$ & $\begin{array}{l}\text { ND } \\
\text { ND }\end{array}$ \\
\hline SB23S & $49-55$ & 6/16/09 & $\begin{array}{l}\text { AGSB23S-W-17951 } \\
\text { AGSB23S-W-17951DUP }\end{array}$ & $\begin{array}{l}\text { Primary sample } \\
\text { Duplicate analysis }\end{array}$ & $\begin{array}{l}59 \\
56\end{array}$ & $\begin{array}{l}0.8 \mathrm{~J}^{\mathrm{b}} \\
0.8 \mathrm{~J}\end{array}$ & $\begin{array}{l}\text { ND } \\
\text { ND }\end{array}$ & $\begin{array}{l}\text { ND } \\
\text { ND }\end{array}$ \\
\hline SB36 & $42.7-62.7$ & 6/16/09 & $\begin{array}{l}\text { AGSB36-W-17952 } \\
\text { AGSB36DUP-W-17956 }\end{array}$ & $\begin{array}{l}\text { Primary sample } \\
\text { Replicate sample }\end{array}$ & $\begin{array}{l}5.1 \\
4.6\end{array}$ & $\begin{array}{l}0.4 \mathrm{~J} \\
0.7 \mathrm{~J}\end{array}$ & $\begin{array}{l}\text { ND } \\
\text { ND }\end{array}$ & $\begin{array}{l}\text { ND } \\
\text { ND }\end{array}$ \\
\hline $\begin{array}{l}\mathrm{QC} \\
\mathrm{QC}\end{array}$ & $\begin{array}{l}- \\
-\end{array}$ & $\begin{array}{l}5 / 20 / 09 \\
5 / 20 / 09\end{array}$ & $\begin{array}{l}\text { AGQCBR-W-17926 } \\
\text { AGQCTB-W-17807 }\end{array}$ & $\begin{array}{l}\text { Equipment rinsate } \\
\text { Trip blank }\end{array}$ & $\begin{array}{l}\text { ND } \\
\text { ND }\end{array}$ & $\begin{array}{l}\text { ND } \\
\text { ND }\end{array}$ & $\begin{array}{l}\text { ND } \\
\text { ND }\end{array}$ & $\begin{array}{l}\text { ND } \\
\text { ND }\end{array}$ \\
\hline $\begin{array}{l}\mathrm{QC} \\
\mathrm{QC} \\
\mathrm{QC}\end{array}$ & $\begin{array}{l}- \\
- \\
-\end{array}$ & $\begin{array}{l}6 / 16 / 09 \\
6 / 16 / 09 \\
6 / 16 / 09\end{array}$ & $\begin{array}{l}\text { AGQCIR-W-17957 } \\
\text { AGQCIR-W-17958 } \\
\text { AGQCTB-W-17959 }\end{array}$ & $\begin{array}{l}\text { Equipment rinsate } \\
\text { Equipment rinsate } \\
\text { Trip blank }\end{array}$ & $\begin{array}{l}\text { ND } \\
\text { ND } \\
\text { ND }\end{array}$ & $\begin{array}{l}\text { ND } \\
\text { ND } \\
\text { ND }\end{array}$ & $\begin{array}{l}\text { ND } \\
\text { ND } \\
\text { ND }\end{array}$ & $\begin{array}{l}\text { ND } \\
\text { ND } \\
\text { ND }\end{array}$ \\
\hline
\end{tabular}

a ND, not detected at an instrument detection limit of $0.1 \mu \mathrm{g} / \mathrm{L}$.

b Qualifier J indicates an estimated concentration below the quantitation limit of $1.0 \mu \mathrm{g} / \mathrm{L}$ for the purge-and-trap method. 


\section{TestAmerica}

THE LEAPER IN ENVIRONMENTAL TESTING

TestAmerica Laboratories, Inc.

June 9, 2009

Mr. Clyde Dennis

Argonne National Laboratory

9700 S. Cass Avenue,

Bldg. 203 Office B149

Argonne, IL 60439

Re: Laboratory Project No. 21005

Case: AGRA; SDG: 131854

Dear Mr. Dennis:

Enclosed are analytical results for samples that were received by TestAmerica Burlington on May $22^{\text {nd }}, 2009$. Laboratory identification numbers were assigned, and designated as follows:

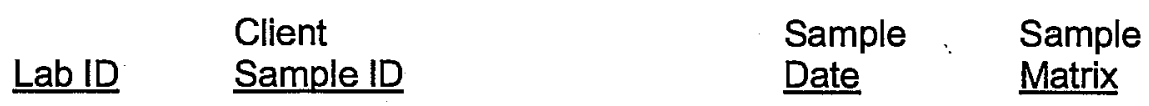

Received: 05/22/09 ETR No: 131854

$\begin{array}{llll}796165 & \text { AG-GW2-W-17806 } & 05 / 20 / 09 & \text { WATER } \\ 796166 & \text { AG-QCTB-W-17807 } & 05 / 20 / 09 & \text { WATER } \\ 796167 & \text { VHBLK01 } & 05 / 22 / 09 & \text { WATER }\end{array}$

Documentation of the condition of the samples at the time of their receipt and any exception to the laboratory's Sample Acceptance Policy is documented in the Sample Handling section of this submittal. The samples, as received, were not acid preserved. On that basis, the laboratory did provide for the analytical work to be performed within seven days of sample collection.

In order to accommodate field length limitations in processing the data summary forms, the laboratory did, in certain instances, abbreviate the sample identifier. The electronically formatted data provides for the full sample identifier.

\section{SOM01.2 Volatile Organics (Trace Level Water)}

A storage blank was prepared for volatile organics analysis, and stored in association with the 


\section{TestAmerica}

THE LEADER IN ENVIRONMENTAL TESTING

storage of the samples. That storage blank, identified as VHBLK01, was carried through the holding period with the samples, and analyzed.

Sample AG-GW2-W-17806 was analyzed at a dilution, based on the results of preliminary screening. An additional, more concentrated analysis was performed on the sample in order to provide a lower reporting limit for those target analytes that were not identified as constituents in the primary analysis. Both sets of results for the analysis of sample AG-GW2-W-17806 are included in this submittal. Each of the analyses associated with the sample set exhibited an acceptable internal standard performance. There was an acceptable recovery of each deuterated monitoring compound (DMC) in the analysis each method blank associated with the analytical work, in the analysis of the storage blank associated with the sample set, and in the analysis of each field sample. Matrix spike and matrix spike duplicate analyses were not performed on the samples in this sample set. A trace concentration of acetone was identified in the analysis of each method blank associated with the analytical work. The concentration level in each analysis was below the established reporting limit, and each analysis did meet the technical acceptance criteria for a compliant method blank analysis. A trace concentration of acetone was identified in the analysis of the storage blank associated with the analytical work. The concentration level in that analysis was below the established reporting limit, and the analysis did meet the technical acceptance criteria for a compliant storage blank analysis. Present in the method blank and storage blank analyses was a non-target constituent that represented a compound that is related to the DMC formulation. The fact that the presence of this compound is not within the laboratory's control is at issue. The derived results for that compound have been qualified with an "X" qualifier to reflect the source of the contamination.

The responses for each target analyte met the relative standard deviation criterion in the initial calibration. The response for each target analyte met the percent difference criterion in the continuing calibration check acquisition. The response for each target analyte met the 50.0 percent difference criterion in each closing calibration check acquisition.

The primary quantitation mass for methylcyclohexane that is specified in the Statement of Work is mass 83 . The laboratory did identify a contribution to mass 83 from 1,2-dichloropropane- $d_{6}$, one of the deuterated monitoring compounds (DMCs). The laboratory did change the primary quantitation mass assignment to mass 55 for the quantification of methylcyclohexane.

Manual integration was employed in deriving certain of the analytical results. The values that have been derived from manual integration are qualified on the quantitation reports. Extracted ion current profiles for each manual integration are included in the data package, and further documented in the Sample Preparation section of this submittal.

Any reference within this report to Severn Trent Laboratories, Inc. or STL, should be understood to refer to TestAmerica Laboratories, Inc. (formerly known as Severn Trent Laboratories, Inc.) The analytical results associated with the samples presented in this test report were generated under a quality system that adheres to requirements specified in the NELAC standard. Release of the data in this test report and any associated electronic deliverables is authorized by the Laboratory Director's designee as verified by the following signature. 


\section{TestAmerica \\ THE LEADER IN ENVIRONMENTAL TESTING}

If there are any questions regarding this submittal, please contact me at $802660-1990$.

Sincerely,

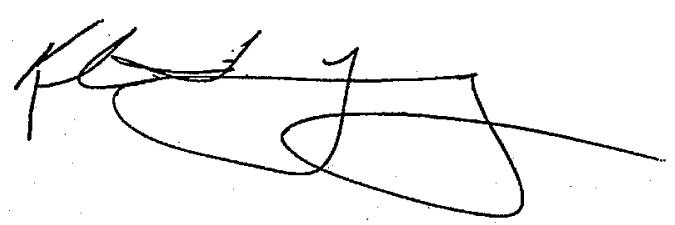

Kirk F. Young

Project Manager

$\mathrm{KFY} / \mathrm{hsf}$

Enclosure 
TestAmericà Burlington Data Qualifier Definitions

\section{Organic}

U: Compound analyzed but not detected at a concentration above the reporting limit.

J: Estimated value.

$\mathrm{N}$ : Indicates presumptive evidence of a compound. This flag is used only for tentatively identified compounds (TICs) where the identification of a compound is based on a mass spectral library search.

P: $\quad$ SW-846: The relative percent difference for detected concentrations between two GC columns is greater than $40 \%$. Unless otherwise specified the higher of the two values is reported on the Form $I$.

CLP SOW: Greater than $25 \%$ difference for detected concentrations between two $\mathrm{GC}$ columns. Unless otherwise specified the lower of the two values is reported on the Form I.

C: Pesticide result whose identification has been confirmed by GC/MS.

B: $\quad$ Analyte is found in the sample and the associated method blank. The flag is used for tentatively identified compounds as well as positively identified compounds.

E: Compounds whose concentrations exceed the upper limit of the calibration range of the instrument for that specific analysis.

D: Concentrations identified from analysis of the sample at a.secondary dilution.

A: Tentatively identified compound is a suspected aldol condensation product.

$X, Y, Z$ : Laboratory defined flags that may be used alone or combined, as needed. If used, the description of the flag is defined in the project narrative.

\section{Inorganic/Metals}

E: Reported value is estimated due to the presence of interference.

$\mathrm{N}$ : Matrix spike sample recovery is not within control limits.

* Duplicate sample analysis is not within control limits.

B: The result reported is less than the reporting limit but greater than the instrument detection limit.

U: $\quad$ Analyte was analyzed for but not detected above the reporting limit.

Method Codes:

P ICP-AES

MS ICP-MS

CV Cold Vapor AA

AS. Semi-Automated Spectrophotometric 
4397.

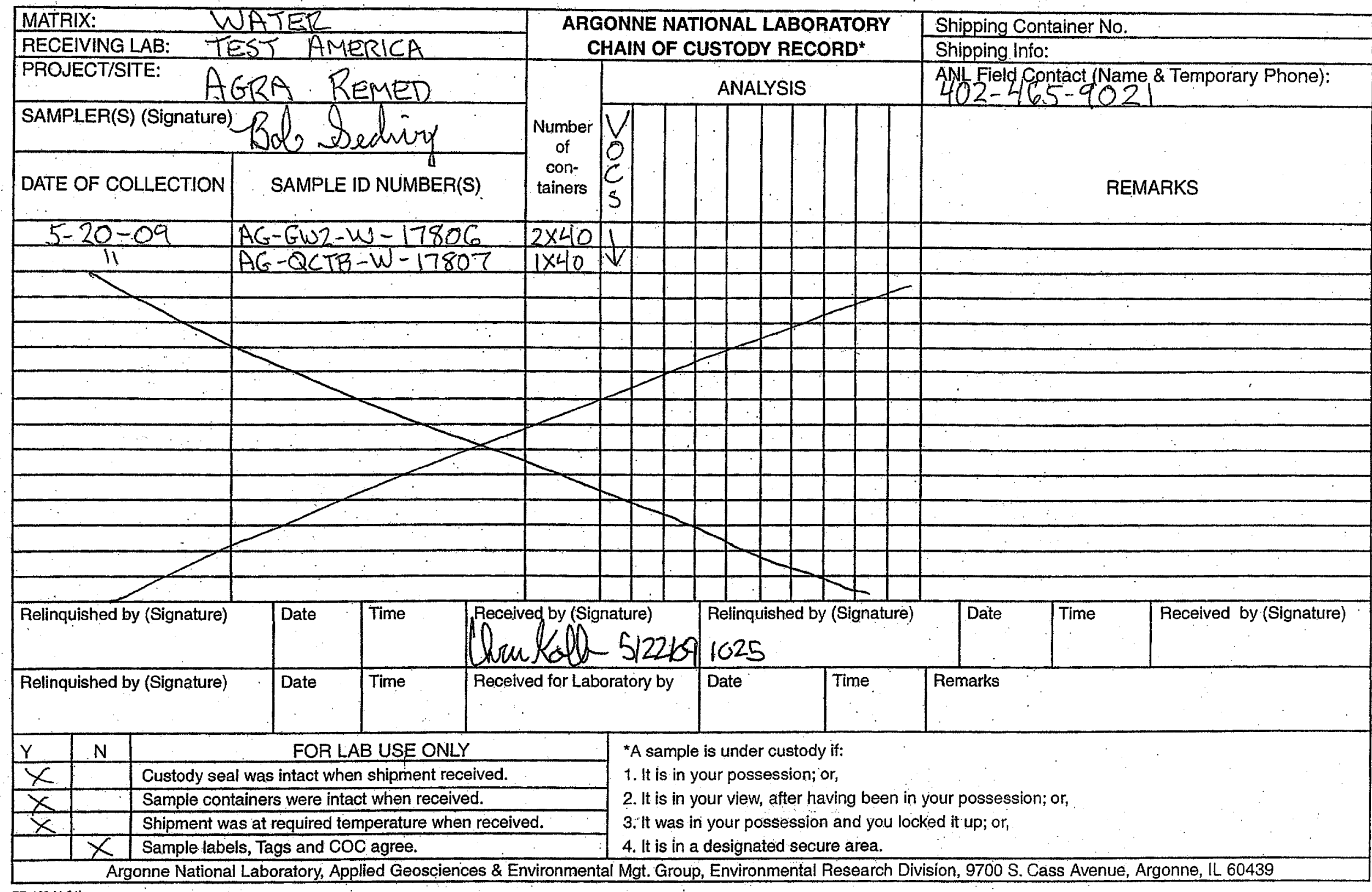


Lab Name: TESTAMERICA BURLINGTON

Lab Code: STLV Case No.: AGRA

Matrix: (SOIL/SED/WATER) Water

Sample wt/vol: $25.0 \quad(\mathrm{~g} / \mathrm{mL}) \mathrm{mL}$

Level: (TRACE/LOW/MED) TRACE

$\%$ Moisture: not dec.

GC Column: DB-624

Soil Extract Volume:

ID : 0.53

(mm)

(uL)

Contract: 21005
SDG No.: 131854

Purge Volume: 25.0

(mL)

\begin{tabular}{|c|c|c|c|}
\hline CAS NO. & COMPOUND & $\begin{array}{l}\text { CONCENTRATION UNITS: } \\
(\mathrm{ug} / \mathrm{L} \text { or } \mathrm{ug} / \mathrm{kg}) \mathrm{ug} / \mathrm{L} \\
\end{array}$ & Q \\
\hline$===========$ & 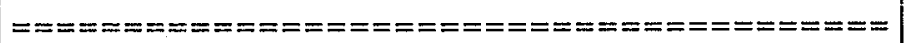 & 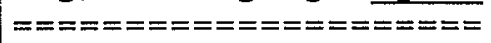 & $=======$ \\
\hline $75-71-8$ & Dichlorodifluoromethane & 9.6 & $\mathrm{U}$ \\
\hline $74-87-3$ & Chloromethane & 9.6 & $\mathrm{U}$ \\
\hline $75-01-4$ & Vinyl chloride & 9.6 & $\mathrm{U}$ \\
\hline $74-83-9$ & Bromomethane & 9.6 & $\mathrm{U}$ \\
\hline $75-00-3$ & Chloroethane & 9.6 & $\mathrm{U}$ \\
\hline $75-69-4$ & Trichlorofluoromethane & 9.6 & $\mathrm{U}$ \\
\hline $75-35-4$ & 1,1-Dichloroethene & 9.6 & $\mathrm{U}$ \\
\hline $76-13-1$ & $1,1,2$-Trichloro-1,2,2-trifluoroethane & 9.6 & $\mathrm{U}$ \\
\hline $67-64-1$ & Acetone & 83 & JB \\
\hline $75-15-0$ & Carbon disulfide & 9.6 & $\mathrm{U}$ \\
\hline $79-20-9$ & Methyl acetate & 9.6 & U \\
\hline $75-09-2$ & Methylene chloride & 9.6 & $\mathrm{U}$ \\
\hline $156-60-5$ & trans-1,2-Dichloroethene & 9.6 & $\mathrm{U}$ \\
\hline $1634-04-4$ & Methyl tert-butyl ether & 9.6 & $\mathrm{U}$ \\
\hline $75-34-3$ & 1,1-Dichloroethane & 9.6 & $\mathrm{U}$ \\
\hline $156-59-2$ & cis-1,2-Dichloroethene & 9.6 & $\mathrm{U}$ \\
\hline $78-93-3$ & 2-Butanone & 210 & \\
\hline $74-97-5$ & Bromochloromethane & 9.6 & $\overline{\mathrm{U}}$ \\
\hline $67-66-3$ & Chloroform & 25 & \\
\hline $71-55-6$ & $1,1,1$-Trichloroethane & 9.6 & $\overline{\mathrm{U}}$ \\
\hline $110-82-7$ & Cyclohexane & 9.6 & $\mathrm{U}$ \\
\hline $56-23-5$ & Carbon tetrachloride & 2500 & $\mathrm{E}$ \\
\hline $71-43-2$ & Benzene & 9.6 & $\mathrm{U}$ \\
\hline $107-06-2$ & 1,2-Dichloroethane & 9.6 & $\mathrm{U}$ \\
\hline
\end{tabular}

Report 1,4-Dioxane for Low-Medium VOA analysis only 
$1 B$ - FORM I VOA-2

VOLATILE ORGANICS ANALYSIS DATA SHEET
EPA SAMPLE NO.

AGGW2W17806
Lab Name: TESTAMERICA BURLINGTON

Lab Code: STLV Case No.: AGRA

Matrix: (SOIL/SED/WATER) Water

Sample wt/vol: 25.0

$(\mathrm{g} / \mathrm{mL}) \mathrm{mL}$

Level: (TRACE/LOW/MED) TRACE

$\%$ Moisture: not dec.

GC Column: DB-624

ID $: 0.53$

Soil Extract Volume:

Purge Volume: 25.0
Contract: 21005

Mod. Ref No.:
Lab Sample ID: 796165

Lab File ID: 796165D2

Date Received: 05/22/2009

Date Analyzed: 05/27/2009

Dilution Factor: 19.1

(uL) Soil Aliquot Volume:

(uL)

\begin{tabular}{|c|c|c|c|}
\hline $\begin{array}{l}\text { CAS NO. } \\
=========== \\
79-01-6 \\
108-87-2 \\
78-87-5 \\
75-27-4 \\
10061-01-5 \\
108-10-1 \\
108-88-3 \\
10061-02-6 \\
79-00-5 \\
127-18-4 \\
591-78-6 \\
124-48-1 \\
106-93-4 \\
108-90-7 \\
100-41-4 \\
95-47-6 \\
179601-23-1 \\
100-42-5 \\
75-25-2 \\
98-82-8 \\
79-34-5 \\
541-73-1 \\
106-46-7 \\
95-50-1 \\
96-12-8 \\
120-82-1 \\
87-61-6\end{array}$ & $\begin{array}{l}\text { COMPOUND } \\
============================= \\
\text { Trichloroethene } \\
\text { Methylcyclohexane } \\
\text { 1,2-Dichloropropane } \\
\text { Bromodichloromethane } \\
\text { cis-1,3-Dichloropropene } \\
\text { 4-Methyl-2-pentanone } \\
\text { Toluene } \\
\text { trans-1,3-Dichloropropene } \\
\text { 1,1,2-Trichloroethane } \\
\text { Tetrachloroethene } \\
\text { 2-Hexanone } \\
\text { Dibromochloromethane } \\
\text { 1,2-Dibromoethane } \\
\text { Chlorobenzene } \\
\text { Ethylbenzene } \\
\text { o-Xylene } \\
\text { m,p-Xylene } \\
\text { Styrene } \\
\text { Bromoform } \\
\text { Isopropylbenzene } \\
\text { 1, 1,2,2-Tetrachloroethane } \\
\text { 1,3-Dichlorobenzene } \\
\text { 1,4-Dichlorobenzene } \\
\text { 1,2-Dichlorobenzene } \\
\text { 1,2-Dibromo-3-chloropropane } \\
\text { 1,2, 4-Trichlorobenzene } \\
1,2,3-\text { Trichlorobenzene }\end{array}$ & $\begin{array}{rr}\text { CONCENTRATION UNITS } \\
\text { (ug/L or ug/kg) } \\
\text { ug } / \mathrm{L} \\
================ \\
9.6 \\
9.6 \\
9.6 \\
9.6 \\
9.6 \\
96 \\
9.6 \\
9.6 \\
9.6 \\
9.6 \\
96 \\
9.6 \\
9.6 \\
9.6 \\
9.6 \\
9.6 \\
9.6 \\
9.6 \\
9.6 \\
9.6 \\
9.6 \\
9.6 \\
9.6 \\
9.6 \\
9.6 \\
9.6 \\
9.6\end{array}$ & \begin{tabular}{|l}
$======$ \\
$\mathrm{U}$ \\
$\mathrm{U}$ \\
$\mathrm{U}$ \\
$\mathrm{U}$ \\
$\mathrm{U}$ \\
$\mathrm{U}$ \\
$\mathrm{U}$ \\
$\mathrm{U}$ \\
$\mathrm{U}$ \\
$\mathrm{U}$ \\
$\mathrm{U}$ \\
$\mathrm{U}$ \\
$\mathrm{U}$ \\
$\mathrm{U}$ \\
$\mathrm{U}$ \\
$\mathrm{U}$ \\
$\mathrm{U}$ \\
$\mathrm{U}$ \\
$\mathrm{U}$ \\
$\mathrm{U}$ \\
$\mathrm{U}$ \\
$\mathrm{U}$ \\
$\mathrm{U}$ \\
$\mathrm{U}$ \\
$\mathrm{U}$ \\
$\mathrm{U}$ \\
$\mathrm{U}$
\end{tabular} \\
\hline
\end{tabular}


$1 A$ - FORM I VOA-1

VOLATILE ORGANICS ANALYSIS DATA SHEET
EPA SAMPLE NO.

AGGW2W17806D
Lab Name: TESTAMERICA BURLINGTON

Lab Code: STLV Case No.: AGRA

Matrix: (SOIL/SED/WATER) Water

Sample wt/vol: $25.0 \quad(\mathrm{~g} / \mathrm{mL}) \mathrm{mL}$

Level: (TRACE/LOW/MED) TRACE

\% Moisture: not dec.

GC Column: DB-624

ID: 0.53

(mm)

Contract : 21005
SDG NO. : 131854
Soil Extract Volume:

Purge Volume: 25.0
Lab Sample ID: 796165D1

Lab File ID: $796165 \mathrm{D}$

Date Received: 05/22/2009

Date Analyzed: 05/27/2009

Dilution Factor: 191.0

Soil Aliquot Volume:

(uL)

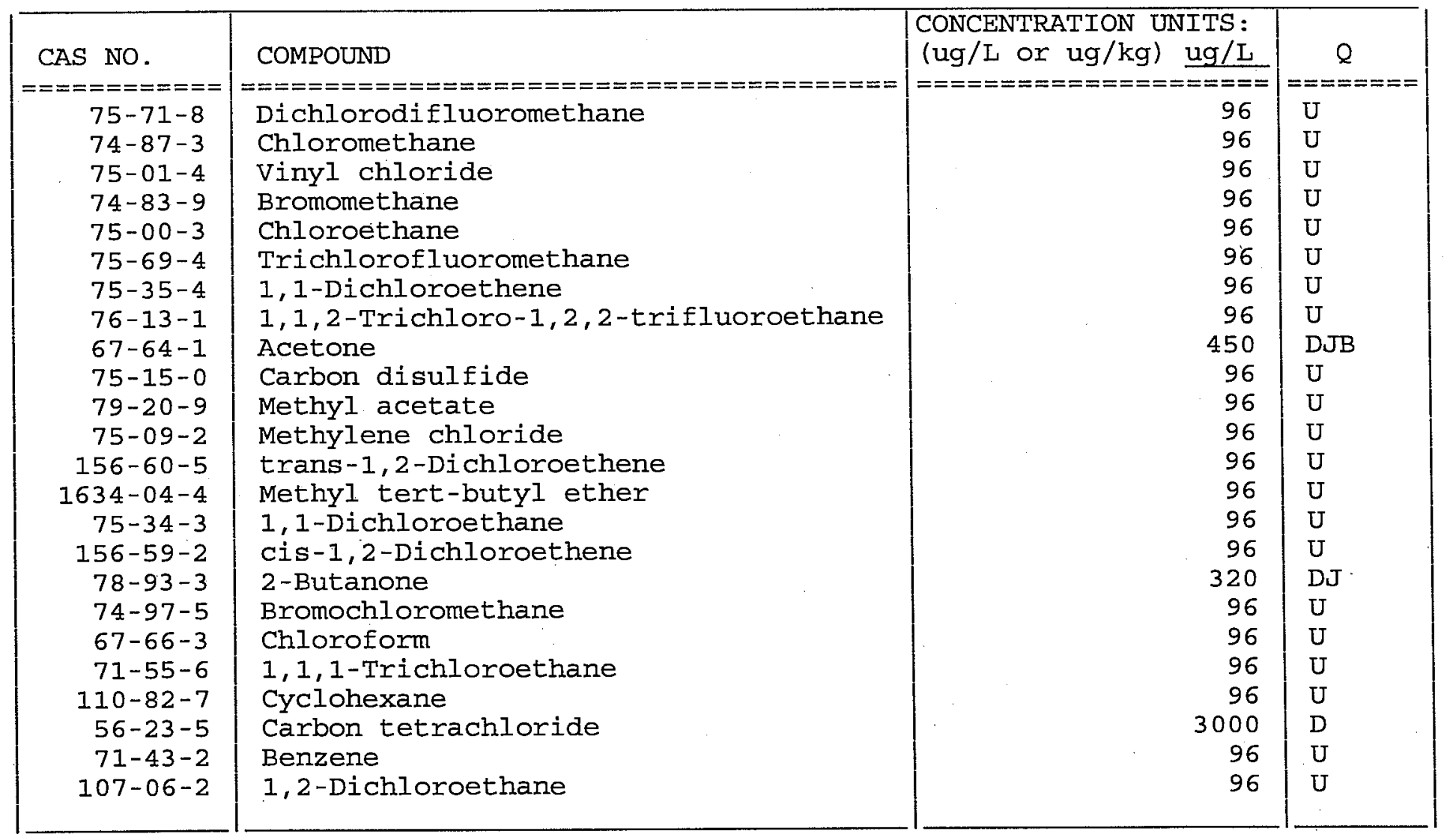

Report 1,4-Dioxane for Low-Medium VOA analysis only 
$1 B$ - FORM I VOA-2

VOLATILE ORGANICS ANALYSIS DATA SHEET
EPA SAMPLE NO. AGGW2W17806D
Lab Name: TESTAMERICA BURLINGTON

Lab Code: STLV Case No.: AGRA

Matrix: (SOIL/SED/WATER) Water

Sample wt/vol: $25.0 \quad(\mathrm{~g} / \mathrm{mL}) \mathrm{mL}$

Level: (TRACE/LOW/MED) TRACE

\% Moisture: not dec.

GC Column: DB-624

ID $: 0.53$

Soil Extract Volume:

Purge Volume: 25.0
Contract: 21005

Mod. Ref No.:
SDG No.: 131854
Lab Sample ID: 796165D1

Lab File ID: $796165 \mathrm{D}$

Date Received: 05/22/2009

Date Analyzed: 05/27/2009

Dilution Factor: 191.0

(uL) Soil Aliquot Volume:

(uI)

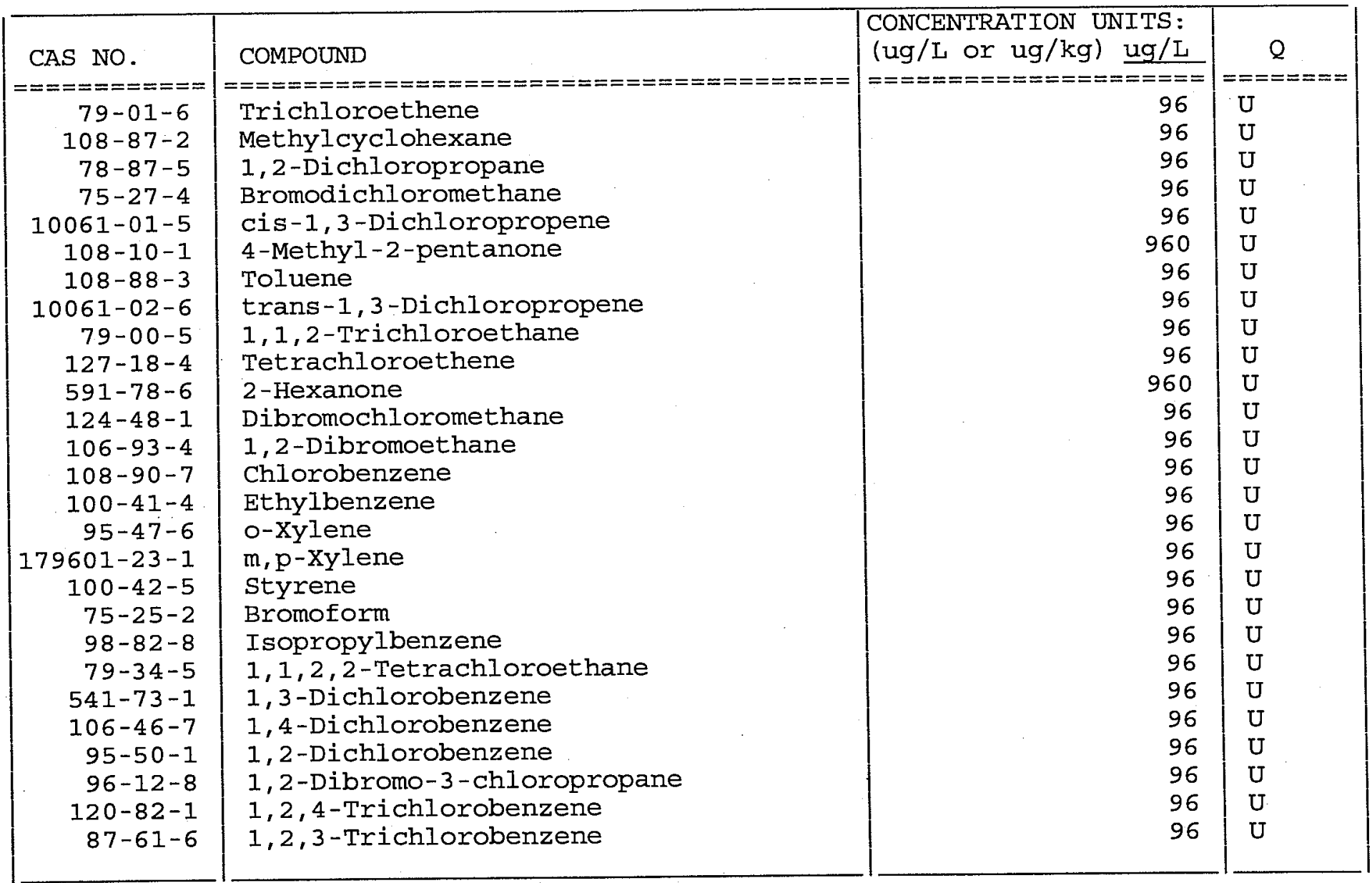


$1 A$ - FORM I VOA-1

VOLATILE ORGANICS ANALYSIS DATA SHEET

EPA SAMPLE NO.

Lab Name: TESTAMERICA BURLINGTON

Lab Code: STLV Case No.: AGRA

Matrix: (SOIL/SED/WATER) Water

Sample wt/vol: $25.0 \quad(\mathrm{~g} / \mathrm{mL}) \mathrm{mL}$

Level: (TRACE/LOW/MED) TRACE

\% Moisture: not dec.

GC Column: DB-624

ID : 0.53

Soil Extract Volume:

Purge volume: 25.0
Contract: 21005

Mod. Ref No.:
Lab Sample ID: 796166

Lab File ID: 796166

Date Received: 05/22/2009

Date Analyzed: 05/27/2009

Dilution Factor: 1.0

Soil Aliquot Volume:

(mL)

\begin{tabular}{|c|c|c|c|}
\hline \begin{tabular}{|c|} 
CAS NO. \\
$==========$ \\
$75-71-8$ \\
$74-87-3$ \\
$75-01-4$ \\
$74-83-9$ \\
$75-00-3$ \\
$75-69-4$ \\
$75-35-4$ \\
$76-13-1$ \\
$67-64-1$ \\
$75-15-0$ \\
$79-20-9$ \\
$75-09-2$ \\
$156-60-5$ \\
$1634-04-4$ \\
$75-34-3$ \\
$156-59-2$ \\
$78-93-3$ \\
$74-97-5$ \\
$67-66-3$ \\
$71-55-6$ \\
$110-82-7$ \\
$56-23-5$ \\
$71-43-2$ \\
$107-06-2$
\end{tabular} & $\begin{array}{l}\text { COMPOUND } \\
============================== \\
\text { Dichlorodifluoromethane } \\
\text { Chloromethane } \\
\text { Vinyl chloride } \\
\text { Bromomethane } \\
\text { Chloroethane } \\
\text { Trichlorofluoromethane } \\
1,1-\text { Dichloroethene } \\
1,1,2-\text { Trichloro-1,2,2-trifluoroethane } \\
\text { Acetone } \\
\text { Carbon disulfide } \\
\text { Methyl acetate } \\
\text { Methylene chloride } \\
\text { trans-1,2-Dichloroethene } \\
\text { Methyl tert-butyl ether } \\
1,1-D i c h l o r o e t h a n e \\
\text { cis-1,2-Dichloroethene } \\
2-\text { Butanone } \\
\text { Bromochloromethane } \\
\text { Chloroform } \\
1,1,1-\text { Trichloroethane } \\
\text { Cyclohexane } \\
\text { Carbon tetrachloride } \\
\text { Benzene } \\
1,2-D i c h l o r o e t h a n e\end{array}$ & $\begin{array}{|cc|}\text { (ugNCENTRATION UNITS: } \\
=============== \\
\text { or ug } / \mathrm{kg} / \mathrm{L} \\
0.50 \\
0.50 \\
0.50 \\
0.50 \\
0.50 \\
0.50 \\
0.50 \\
0.50 \\
4.4 \\
0.50 \\
0.50 \\
0.50 \\
0.50 \\
0.50 \\
0.50 \\
0.50 \\
5.0 \\
0.50 \\
0.50 \\
0.50 \\
0.50 \\
0.50 \\
0.50 \\
0.50\end{array}$ & \begin{tabular}{|l}
$=$ \\
$Q======$ \\
$U$ \\
$U$ \\
$U$ \\
$U$ \\
$U$ \\
$U$ \\
$U$ \\
$U$ \\
$J B$ \\
$U$ \\
$U$ \\
$U$ \\
$U$ \\
$U$ \\
$U$ \\
$U$ \\
$U$ \\
$U$ \\
$U$ \\
$U$ \\
$U$ \\
$U$ \\
$U$ \\
$U$
\end{tabular} \\
\hline
\end{tabular}

Report 1,4-Dioxane for Low-Medium VOA analysis only 
$1 B$ - FORM I VOA-2

VOLATILE ORGANICS ANALYSIS DATA SHEET
EPA SAMPLE NO.
Lab Name: TESTAMERICA BURLINGTON

Lab code: STLV Case No.: AGRA

Matrix: (SOIL/SED/WATER) Water

Sample wt/vol: 25.0

$(\mathrm{g} / \mathrm{mL}) \mathrm{mL}$

Level: (TRACE/LOW/MED) TRACE

\% Moisture: not dec.

GC Column: DB-624

ID: 0.53

Soil Extract Volume:

Purge Volume: 25.0
Contract : 21005

Mod. Ref No.:
Lab Sample ID: 796166

Lab File ID: 796166

Date Received: 05/22/2009

Date Analyzed: 05/27/2009

Dilution Factor: 1.0

(uL) Soil Aliquot Volume:

(uL)

\begin{tabular}{|c|c|c|c|}
\hline $\begin{array}{r}\text { CAS NO. } \\
========== \\
79-01-6 \\
108-87-2 \\
78-87-5 \\
75-27-4 \\
10061-01-5 \\
108-10-1 \\
108-88-3 \\
10061-02-6 \\
79-00-5 \\
127-18-4 \\
591-78-6 \\
124-48-1 \\
106-93-4 \\
108-90-7 \\
100-41-4 \\
95-47-6 \\
179601-23-1 \\
100-42-5 \\
75-25-2 \\
98-82-8 \\
79-34-5 \\
541-73-1 \\
106-46-7 \\
95-50-1 \\
96-12-8 \\
120-82-1 \\
87-61-6\end{array}$ & 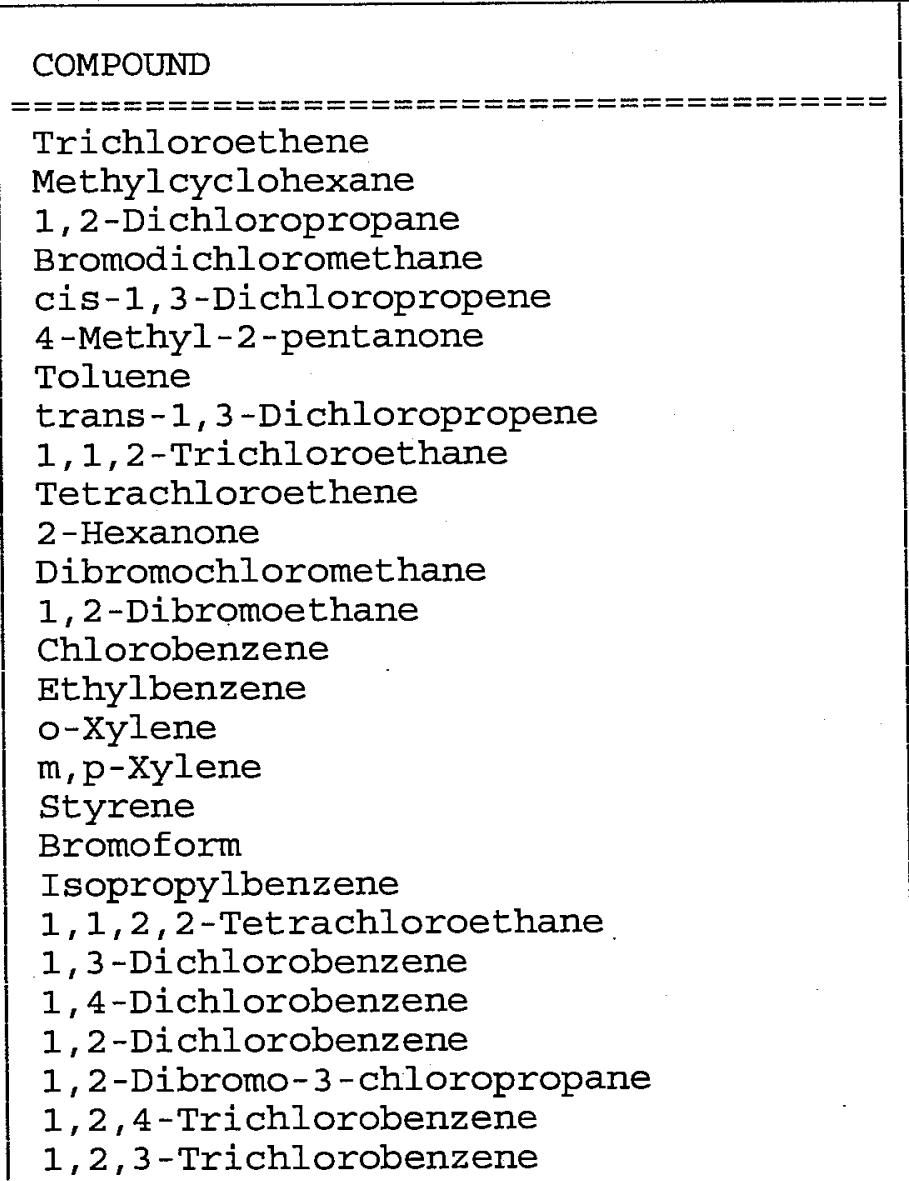 & \begin{tabular}{|c|c|} 
CONCENTRATION UNITS: \\
(ug/L or ug/kg) & ug/L \\
$================$ \\
0.50 \\
0.50 \\
0.50 \\
0.50 \\
0.50 \\
5.0 \\
0.90 \\
0.50 \\
0.50 \\
0.50 \\
5.0 \\
0.50 \\
0.50 \\
0.50 \\
0.50 \\
0.50 \\
0.50 \\
0.50 \\
0.50 \\
0.50 \\
0.50 \\
0.50 \\
0.50 \\
0.50 \\
0.50 \\
0.50 \\
0.50
\end{tabular} & $\begin{array}{c}Q \\
====== \\
U \\
U \\
U \\
U \\
U \\
U\end{array}$ \\
\hline
\end{tabular}


IA - FORM I VOA-1

VOLATILE. ORGANICS ANALYSIS DATA SHEET
EPA SAMPLE NO.

VHBLK01
Lab Name: TESTAMERICA BURLINGTON

Lab Code: STLV Case No.: AGRA

Matrix: (SOIL/SED/WATER) water

Sample wt/vol: 25.0

$(\mathrm{g} / \mathrm{mL}) \mathrm{mL}$

Level : (TRACE/LOW/MED) TRACE

\% Moisture: not dec.

GC Column: DB-624

Soil Extract Volume:

ID : 0.53

(mm)

(uL)

Contract $: 21005$

Mod. Ref No.:
SDG No.: 131854
Lab Sample ID: 796167

Lab File ID: 796167

Date Received:

Date Analyzed: 05/29/2009

Dilution Factor: 1.0

Soil Aliquot Volume:

Purge Volume: 25.0

(mL)

\begin{tabular}{|c|c|c|c|}
\hline CAS NO. & COMPOUND & $\begin{array}{l}\text { CONCENTRATION UNITS: } \\
\text { (ug/L or ug/kg) ug/L }\end{array}$ & $\mathrm{Q}$ \\
\hline$===========1$ & 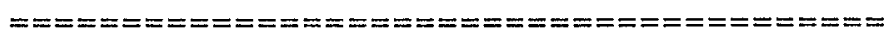 & 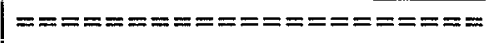 & $========$ \\
\hline $75-71-8$ & Dichlorodifluoromethane & 0.50 & $\mathrm{U}$ \\
\hline $74-87-3$ & Chloromethane & 0.50 & $\mathrm{U}$ \\
\hline $75-01-4$ & Vinyl chloride & 0.50 & $\mathrm{U}$ \\
\hline $74-83-9$ & Bromomethane & 0.50 & $\mathrm{U}$ \\
\hline $75-00-3$ & Chloroethane & 0.50 & $\mathrm{U}$ \\
\hline $75-69-4$ & Trichlorofluoromethane & 0.50 & $\mathrm{U}$ \\
\hline $75-35-4$ & 1,1-Dichloroethene & 0.50 & $\mathrm{U}$ \\
\hline $76-13-1$ & 1,1,2-Trichloro-1,2,2-trifluoroethane & 0.50 & $\mathrm{U}$ \\
\hline $67-64-1$ & Acetone & 2.7 & JB \\
\hline $75-15-0$ & Carbon disulfide & 0.50 & $\mathrm{U}$ \\
\hline $79-20-9$ & Methyl acetate & 0.50 & $\mathrm{U}$ \\
\hline $75-09-2$ & Methylene chloride & 0.50 & $\mathrm{U}$ \\
\hline $156-60-5$ & trans-1,2-Dichloroethene & 0.50 & $\mathrm{U}$ \\
\hline $1634-04-4$ & Methyl tert-butyl ether & 0.50 & $\mathrm{U}$ \\
\hline $75-34-3$ & 1,1-Dichloroethane & 0.50 & $\mathrm{U}$ \\
\hline $156-59-2$ & cis-1,2-Dichloroethene & 0.50 & $\mathrm{U}$ \\
\hline $78-93-3$ & 2-Butanone & 5.0 & $\mathrm{U}$ \\
\hline $74-97-5$ & Bromochloromethane & 0.50 & $\mathrm{U}$ \\
\hline $67-66-3$ & Chloroform & 0.50 & $\mathrm{U}$ \\
\hline $71-55-6$ & 1,1,1-Trichloroethane & 0.50 & $\mathrm{U}$ \\
\hline $110-82-7$ & Cyclohexane & 0.50 & $\mathrm{U}$ \\
\hline $56-23-5$ & Carbon tetrachloride & 0.50 & $\mathrm{U}$ \\
\hline $71-43-2$ & Benzene & 0.50 & U \\
\hline $107-06-2$ & 1,2-Dichloroethane & 0.50 & $\mathrm{U}$ \\
\hline
\end{tabular}

Report 1,4-Dioxane for Low-Medium VOA analysis only 
$1 B$ - FORM I VOA-2

VOLATILE ORGANICS ANALYSIS DATA SHEET
EPA SAMPLE NO.

VHBLK01
Lab Name: TESTAMERICA BURLINGTON

Iab Code: STLV Case No.: AGRA

Matrix: (SOIL/SED/WATER) Water

Sample wt/vol: 25.0

$(\mathrm{g} / \mathrm{mL}) \mathrm{mL}$

Level: (TRACE/LOW/MED) TRACE

\% Moisture: not dec.

GC Column: DB-624

Soil Extract Volume:

ID : 0.53

(mm)

(uL)

Contract: 21005

Mod. Ref No.:
SDG No.: 131854

Purge Volume: 25.0

(mI)

\begin{tabular}{|c|c|c|c|}
\hline $\begin{array}{l}\text { CAS NO. } \\
========== \\
79-01-6 \\
108-87-2 \\
78-87-5 \\
75-27-4 \\
10061-01-5 \\
108-10-1 \\
108-88-3 \\
10061-02-6 \\
79-00-5 \\
127-18-4 \\
591-78-6 \\
124-48-1 \\
106-93-4 \\
108-90-7 \\
100-41-4 \\
95-47-6 \\
179601-23-1 \\
100-42-5 \\
75-25-2 \\
98-82-8 \\
79-34-5 \\
541-73-1 \\
106-46-7 \\
95-50-1 \\
96-12-8 \\
120-82-1 \\
87-61-6\end{array}$ & 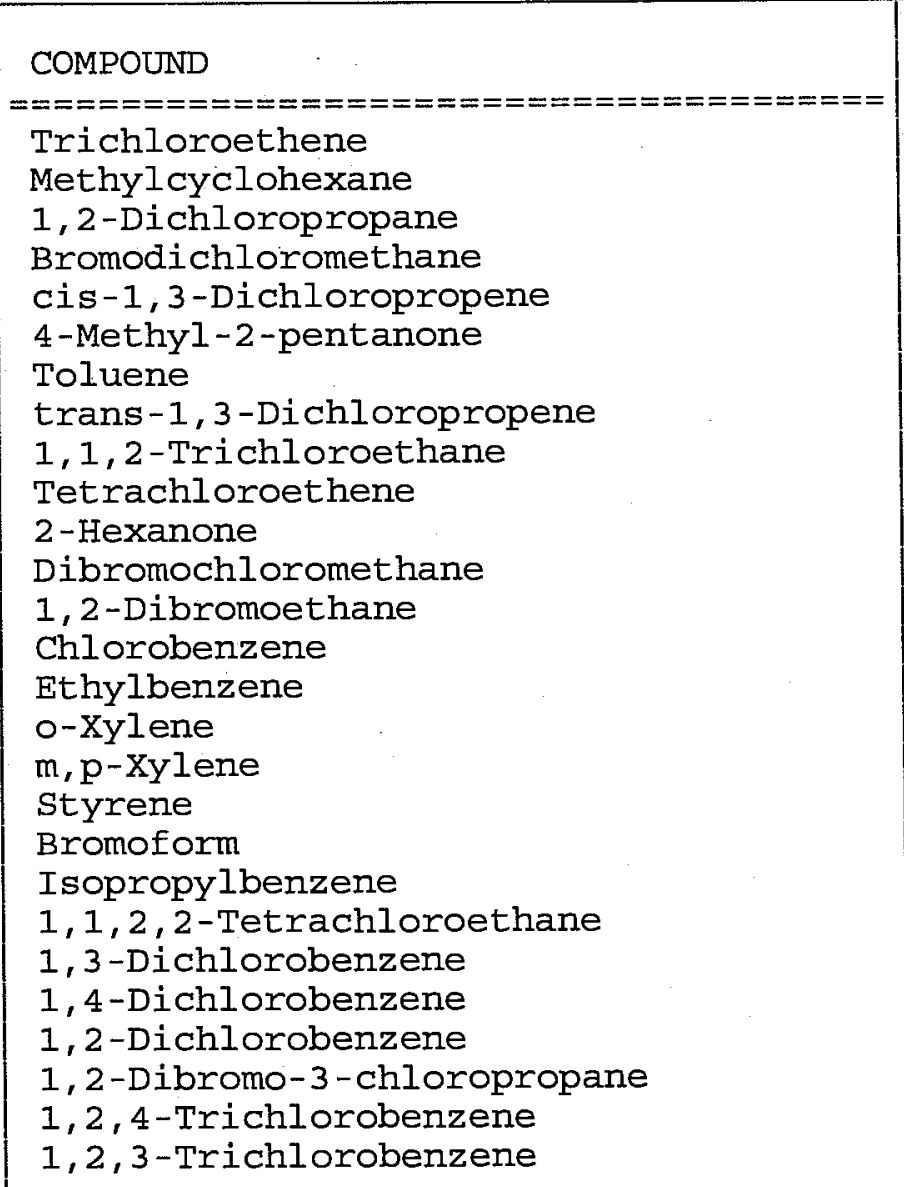 & 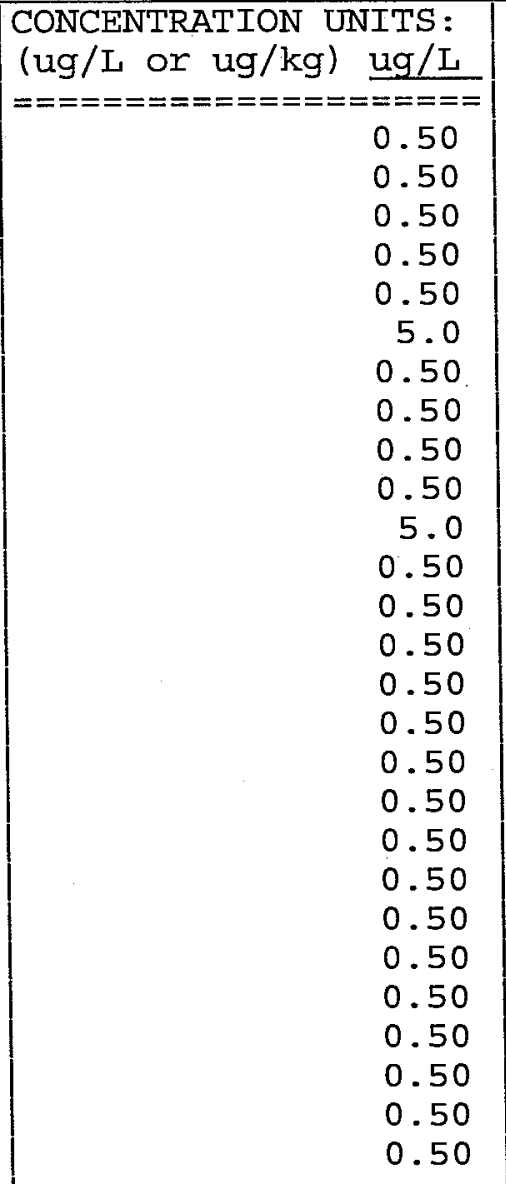 & $\begin{array}{l}======== \\
U \\
U \\
U \\
U \\
U \\
U \\
U \\
U \\
U \\
U \\
U \\
U \\
U \\
U \\
U \\
U \\
U \\
U \\
U \\
U \\
U \\
U \\
U \\
U \\
U \\
U \\
U\end{array}$ \\
\hline
\end{tabular}




\section{TestAmerica}

THE LEADER IN ENVIRONMENTAL TESTING

TestAmerica Laboratories, Inc.

June 26, 2009

Mr. Clyde Dennis

Argonne National Laboratory

9700 S. Cass Avenue

Bldg. 203, Office B149

Argonne, IL 60439

Re: Laboratory Project No. 21005

Case: AGRA; SDG: 132257

Dear Mr. Dennis:

Enclosed are analytical results for samples that were received by TestAmerica Burlington on June $18^{\text {th }}, 2009$. Laboratory identification numbers were assigned, and designated as follows:

$\begin{array}{llll}\text { Lab ID } & \begin{array}{l}\text { Client } \\ \text { Sample ID }\end{array} & \begin{array}{l}\text { Sample } \\ \text { Date } \\ \text { Received: } 06 / 18 / 09\end{array} & \begin{array}{l}\text { Sample } \\ \text { Matrix }\end{array} \\ & & & \\ 7.98627 & \text { AGMWC-W-17943 } & 132257 & \\ 798628 & \text { AGMWJ-W-17945 } & 06 / 15 / 09 & \text { WATER } \\ 798629 & \text { AGMWP-W-17948 } & 06 / 16 / 09 & \text { WATER } \\ 798630 & \text { AGMWQ-W-17949 } & 06 / 16 / 09 & \text { WATER } \\ 798631 & \text { AGQCTB-W-17959 } & 06 / 16 / 09 & \text { WATER } \\ 798632 & \text { VHBLK01 } & 06 / 16 / 09 & \text { WATER } \\ & & 06 / 18 / 09 & \text { WATER }\end{array}$

Documentation of the condition of the samples at the time of their receipt and any exception to the laboratory's Sample Acceptance Policy is documented in the Sample Handling section of this submittal. The samples, as received, were not acid preserved. On that basis, the laboratory did provide for the analytical work to be performed within seven days of sample collection.

In order to accommodate field length limitations in processing the data summary forms, the laboratory did, in certain instances, abbreviate the sample identifier. The electronically formatted data provides for the full sample identifier.

\section{SOM01.2 Volatile Organics (Trace Level Water)}

A storage blank was prepared for volatile organics analysis, and stored in association with the 


\section{Testamerica}

THE LEADER IN ENVIRONMENTAL TESTINC

storage of the samples. That storage blank, identified as VHBLK01, was carried through the holding period with the samples, and analyzed.

Sample AGMWP-W-17948 was analyzed at a dilution, based on the results of preliminary screening. An additional, more concentrated analysis was performed on the sample in order to provide a lower reporting limit for those target analytes that were not identified as constituents in the primary analysis. Both sets of results for the analysis of sample AGMWP-W-17948 are included in this submittal. Each of the analyses associated with the sample set exhibited an acceptable internal standard performance. There was an acceptable recovery of each deuterated monitoring compound (DMC) in the analysis the method blank and instrument blank associated with the analytical work. The analysis of the samples in this sample set did meet the technical acceptance criteria specific to DMC recoveries, although not all DMC recoveries were within the control range in each analysis. The technical acceptance criteria does provide for the recovery of up to three DMCs to fall outside of the control range in the analysis of field samples. The derived recovery of 2-hexanone- $d_{5}$ was elevated in the analysis of samples AGMWC-W17943 and AGMWQ-W-17949, and in the dilution analysis of sample AGMWP-W-17948. Matrix spike and matrix spike duplicate analyses were not performed on the samples in this sample set. The analysis of the method blank associated with the analytical work was free of contamination, as was the analysis of the instrument blank. The analysis of the storage blank associated with the sample set was free of contamination. Present in the method blank, instrument blank, and storage blank analyses was a non-target constituent that represented a compound that is related to the DMC formulation. The fact that the presence of this compound is not within the laboratory's control is at issue. The derived results for that compound have been qualified with an "X" qualifier to reflect the source of the contamination.

The responses for each target analyte met the relative standard deviation criterion in the initial calibration. The response for each target analyte met the percent difference criterion in the continuing calibration check acquisition. The response for each target analyte met the 50.0 percent difference criterion in the closing calibration check acquisition.

The primary quantitation mass for methylcyclohexane that is specified in the Statement of Work is mass 83 . The laboratory did identify a contribution to mass 83 from 1,2-dichloropropane- $d_{6}$, one of the deuterated monitoring compounds (DMCs). The laboratory did change the primary quantitation mass assignment to mass 55 for the quantification of methylcyclohexane.

Manual integration was employed in deriving certain of the analytical results. The values that have been derived from manual integration are qualified on the quantitation reports. Extracted ion current profiles for each manual integration are included in the data package, and further documented in the Sample Preparation section of this submittal.

Any reference within this report to Severn Trent Laboratories, Inc. or STL, should be understood to refer to TestAmerica Laboratories, Inc. (formerly known as Severn Trent Laboratories, Inc.) The analytical results associated with the samples presented in this test report were generated under a quality system that adheres to requirements specified in the NELAC standard. Release of the data in this test report and any associated electronic deliverables is authorized by the Laboratory Director's designee as verified by the following signature. 


\section{TestAmerica \\ THE LEADER IN ENYIRONMENTAL TESTING}

If there are any questions regarding this submittal, please contact me at 802 660-1990.

Sincerely,

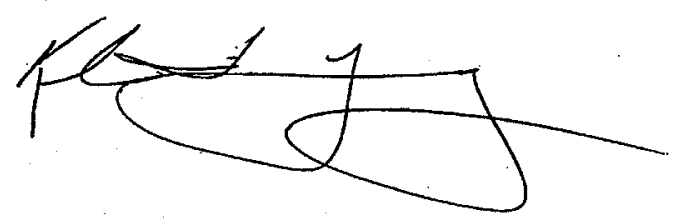

Kirk F. Young

Project Manager

KFY/hsf

Enclosure 


\section{TestAmerica Burlington Data Qualifier Definitions}

\section{Organic}

$\mathrm{U}$ : Compound analyzed but not detected at a concentration above the reporting limit.

$\mathrm{J}: \quad$ Estimated value.

$\mathrm{N}$ : Indicates presumptive evidence of a compound. This flag is used only for tentatively identified compounds (TICs) where the identification of a compound is based on a mass spectral library search.

P: $\quad$ SW-846: The relative percent difference for detected concentrations between two GC columns is greater than $40 \%$. Unless otherwise specified the higher of the two values is reported on the Form $\mathrm{I}$.

CLP SOW: Greater than 25\% difference for detected concentrations between two GC columns. Unless otherwise specified the lower of the two values is reported on the Form 1 .

C: Pesticide result whose identification has been confirmed by GC/MS.

B: Analyte is found in the sample and the associated method blank. The flag is used for tentatively identified compounds as well as positively identified compounds.

E: Compounds whose concentrations exceed the upper limit of the calibration range of the instrument for that specific analysis.

D: Concentrations identified from analysis of the sample at a secondary dilution.

A: Tentatively identified compound is a suspected aldol condensation product.

$X, Y, Z$ : Laboratory defined flags that may be used alone or combined, as needed. If used, the description of the flag is defined in the project narrative.

\section{Inorganic/Metals}

$\mathrm{E}$ : Reported value is estimated due to the presence of interference.

$\mathrm{N}$ : Matrix spike sample recovery is not within control limits.

* Duplicate sample analysis is not within control limits.

B: The result reported is less than the reporting limit but greater than the instrument detection limit.

$\mathrm{U} \quad$ Analyte was analyzed for but not detected above the reporting limit.

Method Codes:

$P \quad$ ICP-AES

MS ICP-MS

CV Cold Vapor AA

AS Semi-Automated Spectrophotometric 


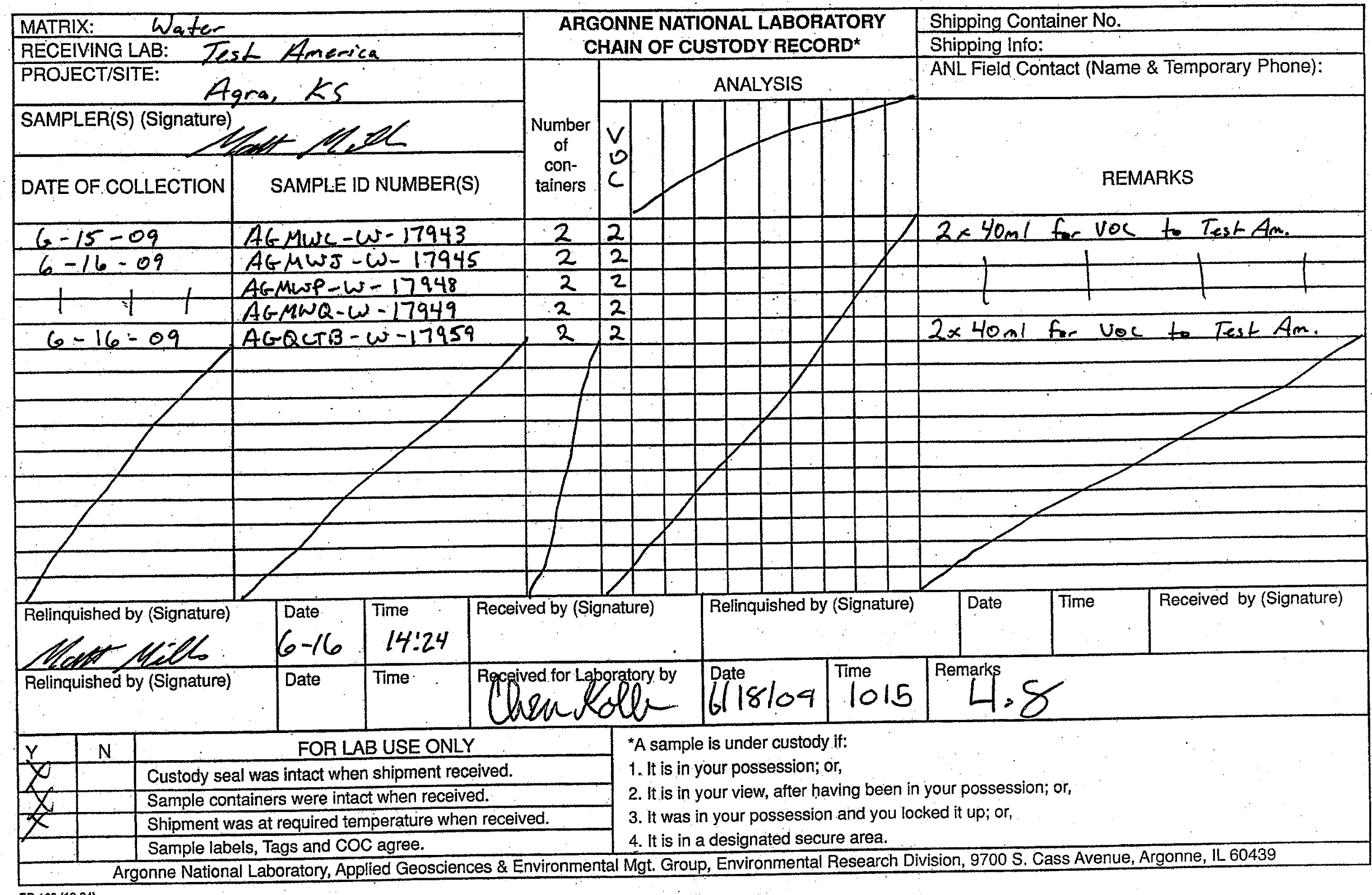


$1 A$ - FORM I VOA-1

VOLATILE ORGANICS ANALYSIS DATA SHEET
EPA SAMPLE NO.

AGMWCW1 7943
Lab Name: TESTAMERICA BURLINGTON

Lab Code: STLV Case No.: AGRA

Matrix: (SOIL/SED/WATER) water

Sample wt/vol: $25.0 \quad(\mathrm{~g} / \mathrm{mL}) \mathrm{mL}$

Level: (TRACE/LOW/MED) TRACE

\% Moisture: not dec.

GC Column: DB-624

ID $: 0.53$

Soil Extract Volume:

Purge Volume: 25.0
Contract: $8 \mathrm{E}-00302$

Mod. Ref No.:
Lab Sample ID: 798627

Lab File ID: 798627

Date Received: 06/18/2009

Date Analyzed: 06/19/2009

Dilution Factor: 1.0

Soil Aliquot Volume:

(uL)

\begin{tabular}{|c|c|c|c|}
\hline $\begin{array}{l}\text { CAS NO. } \\
========== \\
75-71-8 \\
74-87-3 \\
75-01-4 \\
74-83-9 \\
75-00-3 \\
75-69-4 \\
75-35-4 \\
76-13-1 \\
67-64-1 \\
75-15-0 \\
79-20-9 \\
75-09-2 \\
156-60-5 \\
1634-04-4 \\
75-34-3 \\
156-59-2 \\
78-93-3 \\
74-97-5 \\
67-66-3 \\
71-55-6 \\
110-82-7 \\
56-23-5 \\
71-43-2 \\
107-06-2\end{array}$ & $\begin{array}{l}\text { COMPOUND } \\
============================ \\
\text { Dichlorodifluoromethane } \\
\text { Chloromethane } \\
\text { Vinyl chloride } \\
\text { Bromomethane } \\
\text { Chloroethane } \\
\text { Trichlorofluoromethane } \\
1,1-D i c h l o r o e t h e n e \\
1,1,2-\text { Trichloro-1, } 2,2-t r i f l u o r o e t h a n e \\
\text { Acetone } \\
\text { Carbon disulfide } \\
\text { Methyl acetate } \\
\text { Methylene chloride } \\
\text { trans-1,2-Dichloroethene } \\
\text { Methyl tert-butyl ether } \\
1,1-D i c h l o r o e t h a n e \\
\text { cis-1,2-Dichloroethene } \\
2-\text { Butanone } \\
\text { Bromochloromethane } \\
\text { Chloroform } \\
1,1,1-T r i c h l o r o e t h a n e \\
\text { Cyclohexane } \\
\text { Carbon tetrachloride } \\
\text { Benzene } \\
1,2-D i c h l o r o e t h a n e\end{array}$ & $\begin{array}{|cr|}\text { CONCENTRATION UNITS: } \\
\text { (ug/L Or ug/kg) } & \text { ug } / \mathrm{L} \\
================ \\
0.50 \\
0.50 \\
0.50 \\
0.50 \\
0.50 \\
0.50 \\
0.50 \\
0.50 \\
5.0 \\
0.50 \\
0.50 \\
0.50 \\
0.50 \\
0.50 \\
0.50 \\
0.50 \\
5.0 \\
0.50 \\
0.50 \\
0.50 \\
0.50 \\
0.50 \\
0.50 \\
0.50\end{array}$ & \begin{tabular}{c|}
$=======$ \\
$\mathrm{U}$ \\
$\mathrm{U}$ \\
$\mathrm{U}$ \\
$\mathrm{U}$ \\
$\mathrm{U}$ \\
$\mathrm{U}$ \\
$\mathrm{U}$ \\
$\mathrm{U}$ \\
$\mathrm{U}$ \\
$\mathrm{U}$ \\
$\mathrm{U}$ \\
$\mathrm{U}$ \\
$\mathrm{U}$ \\
$\mathrm{U}$ \\
$\mathrm{U}$ \\
$\mathrm{U}$ \\
$\mathrm{U}$ \\
$\mathrm{U}$ \\
$\mathrm{U}$ \\
$\mathrm{U}$ \\
$\mathrm{U}$ \\
$\mathrm{U}$ \\
$\mathrm{U}$ \\
$\mathrm{U}$
\end{tabular} \\
\hline
\end{tabular}

Report 1,4-Dioxane for Low-Medium VOA analysis only 
$1 B$ - FORM I VOA-2

VOLATILE ORGANICS ANALYSIS DATA SHEET

EPA SAMPLE NO.

Lab Name: TESTAMERICA BURLINGTON

Lab Code: STLV Case No.: AGRA

Matrix: (SOIL/SED/WATER) Water

Sample wt/vol: $25.0(\mathrm{~g} / \mathrm{mL}) \mathrm{mL}$

Level: (TRACE/LOW/MED) TRACE

\% Moisture: not dec.

GC Column: DB-624 ID: 0.53 (mm) Dilution Factor: 1.0

Soil Extract Volume:

(uL) Soil Aliquot Volume:

SDG No.: 132257

Purge Volume: 25.0

(mL)

\begin{tabular}{|c|c|c|c|}
\hline $\begin{array}{l}\text { CAS NO. } \\
========== \\
79-01-6 \\
108-87-2 \\
78-87-5 \\
75-27-4 \\
10061-01-5 \\
108-10-1 \\
108-88-3 \\
10061-02-6 \\
79-00-5 \\
127-18-4 \\
591-78-6 \\
124-48-1 \\
106-93-4 \\
108-90-7 \\
100-41-4 \\
95-47-6 \\
179601-23-1 \\
100-42-5 \\
75-25-2 \\
98-82-8 \\
79-34-5 \\
541-73-1 \\
106-46-7 \\
95-50-1 \\
96-12-8 \\
120-82-1 \\
87-61-6\end{array}$ & 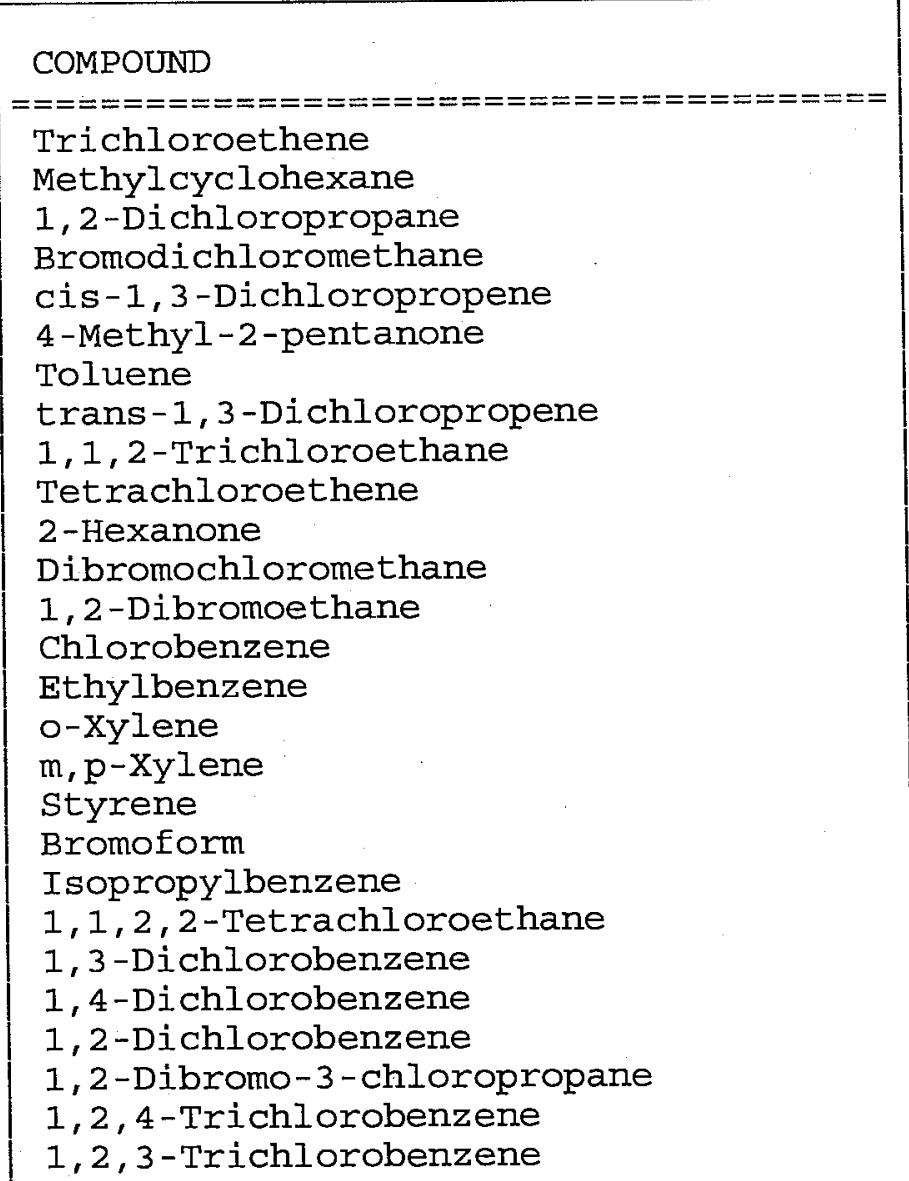 & $\begin{array}{|cr|}\text { CONCENTRATION UNITS: } \\
\text { (ug/L or ug/kg) } & \text { ug } / \mathrm{L} \\
============== \\
0.50 \\
0.50 \\
0.50 \\
0.50 \\
0.50 \\
5.0 \\
0.50 \\
0.50 \\
0.50 \\
0.50 \\
5.0 \\
0.50 \\
0.50 \\
0.50 \\
0.50 \\
0.50 \\
0.50 \\
0.50 \\
0.50 \\
0.50 \\
0.50 \\
0.50 \\
0.50 \\
0.50 \\
0.50 \\
0.50 \\
0.50\end{array}$ & $\begin{array}{l}\text { Q }======== \\
U \\
U \\
U \\
U \\
U \\
U \\
U \\
U \\
U \\
U \\
U \\
U \\
U \\
U \\
U \\
U \\
U \\
U \\
U \\
U \\
U \\
U \\
U \\
U \\
U \\
U \\
U\end{array}$ \\
\hline
\end{tabular}


$1 A$ - FORM I VOA-1

VOLATILE ORGANICS ANALYSIS DATA SHEET
EPA SAMPLE NO.

AGMWJW1 7945
Lab Name: TESTAMERICA BURLINGTON

Lab Code: STLV Case No.: AGRA

Contract: $8 \mathrm{E}-00302$

Mod. Ref No.: SDG No.: 132257

Matrix: (SOIL/SED/WATER) Water

Sample wt/vol: 25.0

$(\mathrm{g} / \mathrm{mL}) \mathrm{mL}$

Level: (TRACE/LOW/MED) TRACE

\% Moisture: not dec.

GC Column: DB-624

ID $: 0.53$

Soil Extract Volume:

Purge Volume: 25.0
Lab Sample ID: 798628

Lab File ID: 798628

Date Received: 06/18/2009

Date Analyzed: 06/19/2009

Dilution Factor: 1.0

Soil Aliquot Volume:

(uL)

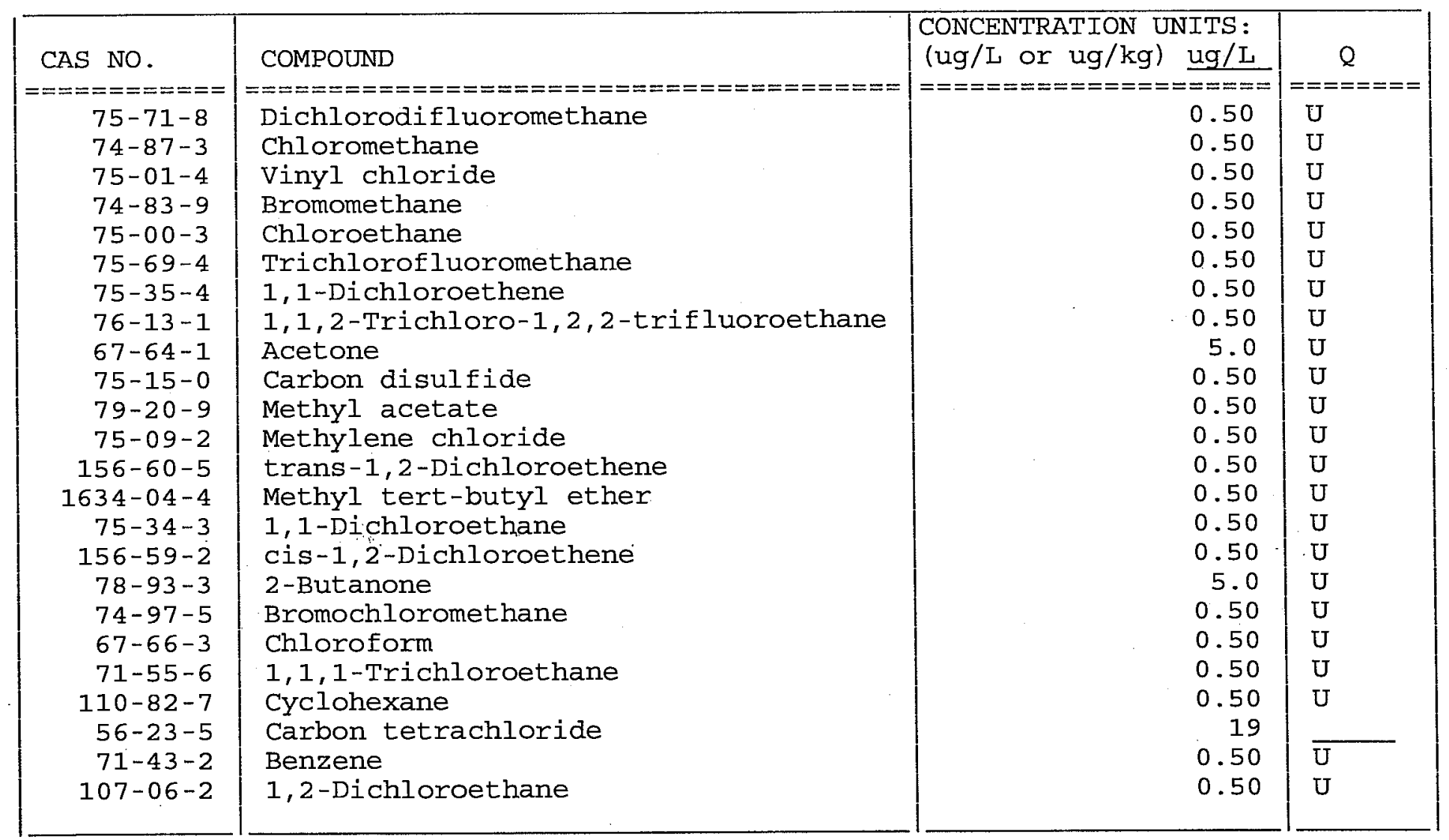

Report 1,4-Dioxane for Low-Medium VOA analysis only 
Lab Name: TESTAMERICA BURLINGTON

Lab Code: STLV Case No.: AGRA

Matrix: (SOIL/SED/WATER) water

Sample wt/vol: $25.0 \quad(\mathrm{~g} / \mathrm{mL}) \mathrm{mL}$

Level: (TRACE/LOW/MED) TRACE

\% Moisture: not dec.

GC Column: DB-624

ID $: 0.53$

Soil Extract Volume:

Purge Volume: 25.0
Contract: 8E-00302

Mod. Ref No.:
Lab Sample ID: 798628

Lab File ID: 798628

Date Received: 06/18/2009

Date Analyzed: 06/19/2009

Dilution Factor: 1.0

Soil Aliquot Volume:

(uL)

\begin{tabular}{|c|c|c|c|}
\hline $\begin{array}{c}\text { CAS NO. } \\
========= \\
79-01-6 \\
108-87-2 \\
78-87-5 \\
75-27-4 \\
10061-01-5 \\
108-10-1 \\
108-88-3 \\
10061-02-6 \\
79-00-5 \\
127-18-4 \\
591-78-6 \\
124-48-1 \\
106-93-4 \\
108-90-7 \\
100-41-4 \\
95-47-6 \\
179601-23-1 \\
100-42-5 \\
75-25-2 \\
98-82-8 \\
79-34-5 \\
541-73-1 \\
106-46-7 \\
95-50-1 \\
96-12-8 \\
120-82-1 \\
87-61-6\end{array}$ & 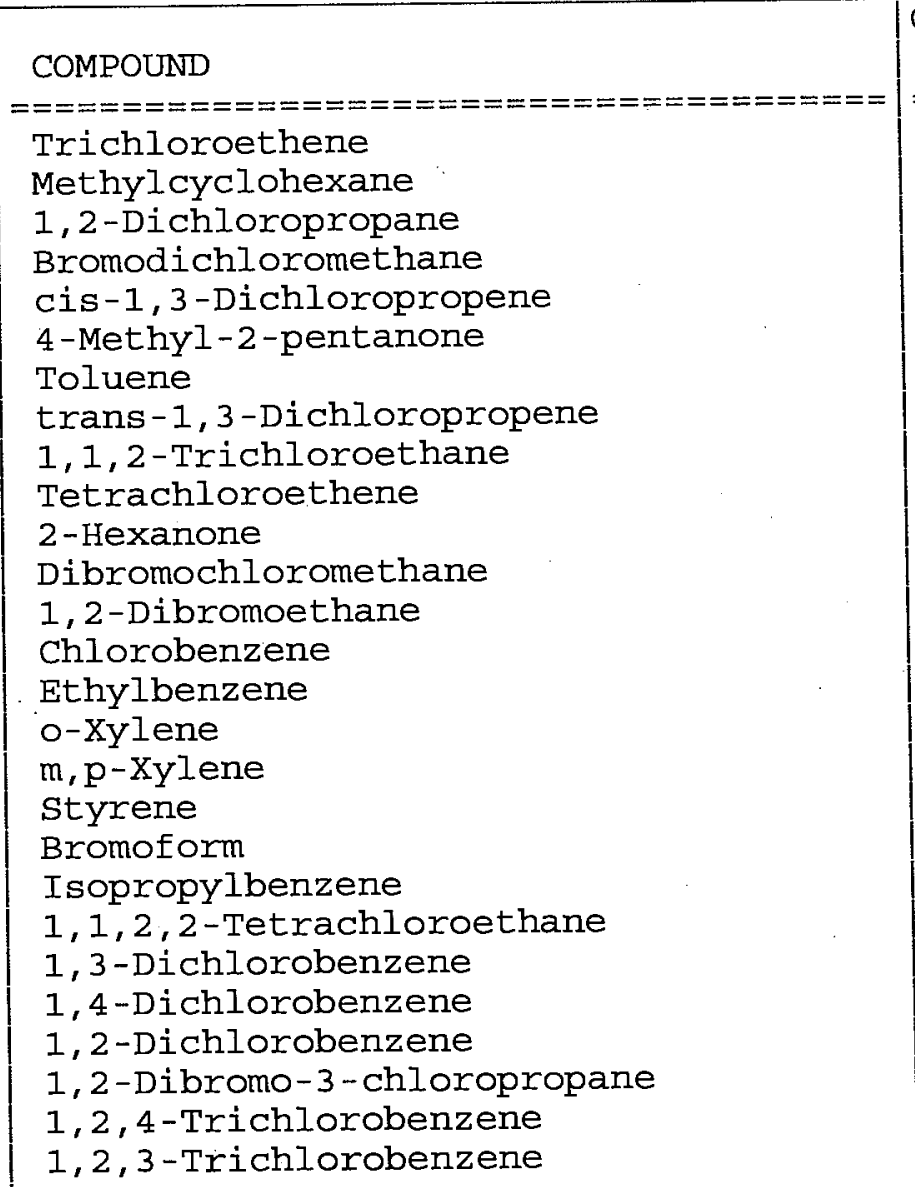 & $\begin{array}{|cr|}\text { CONCENTRATION UNITS : } \\
\text { (ug/L Or ug/kg) } & \text { ug } / \mathrm{L} \\
================== \\
0.50 \\
0.50 \\
0.50 \\
0.50 \\
0.50 \\
5.0 \\
0.50 \\
0.50 \\
0.50 \\
0.50 \\
5.0 \\
0.50 \\
0.50 \\
0.50 \\
0.50 \\
0.50 \\
0.50 \\
0.50 \\
0.50 \\
0.50 \\
0.50 \\
0.50 \\
0.50 \\
0.50 \\
0.50 \\
0.50 \\
0.50\end{array}$ & \begin{tabular}{|l} 
Q \\
$=======$ \\
$U$ \\
$U$ \\
$U$ \\
$U$ \\
$U$ \\
$U$ \\
$U$ \\
$U$ \\
$U$ \\
$U$ \\
$U$ \\
$U$ \\
$U$ \\
$U$ \\
$U$ \\
$U$ \\
$U$ \\
$U$ \\
$U$ \\
$U$ \\
$U$ \\
$U$ \\
$U$ \\
$U$ \\
$U$ \\
$U$ \\
$U$
\end{tabular} \\
\hline
\end{tabular}

SOM01. 2 
IA - FORM I VOA-1

VOLATILE ORGANICS ANALYSIS DATA SHEET
EPA SAMPLE NO.

GMWPW1 7948
Lab Name: TESTAMERICA BURLINGTON

Lab Code: STLV Case No.: AGRA

Matrix: (SOIL/SED/WATER) water

Sample wt/vol: 25.0

$(\mathrm{g} / \mathrm{mL}) \mathrm{mL}$

Level: (TRACE/LOW/MED) TRACE

$\%$ Moisture: not dec.

GC Column: DB-624

ID $: 0.53 \quad(\mathrm{~mm})$

Soil Extract Volume:

(uL)

Contract: 8E-00302

Mod. Ref No.:

Lab Sample ID: 798629

Lab File ID: 798629D2

Dilution Factor: 2.8

Soil Aliquot Volume:
SDG No.: 132257

Purge Volume: 25.0

Date Received: 06/18/2009

Date Analyzed: 06/19/2009

(uI)

(mL)

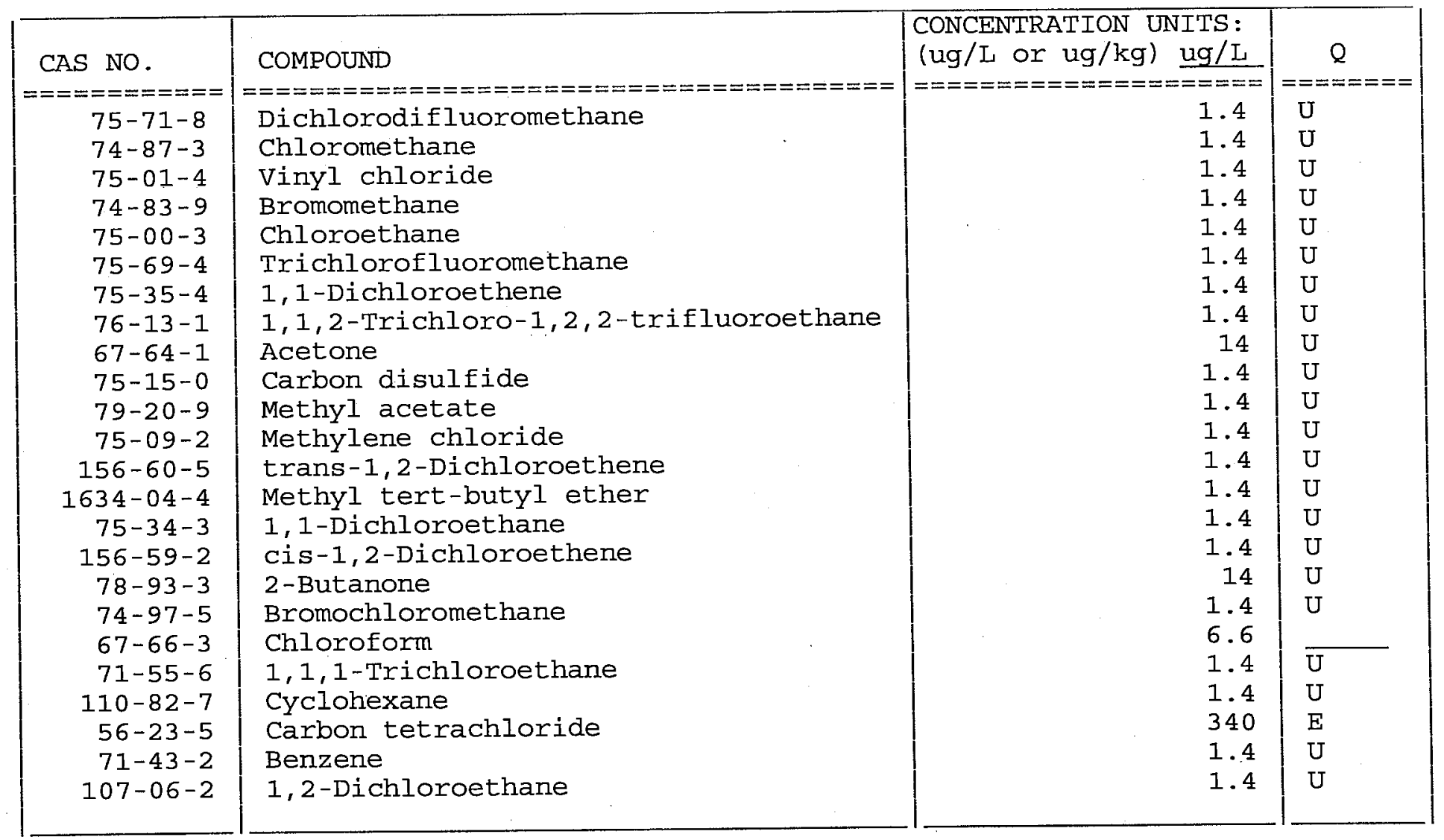

Report 1,4-Dioxane for Low-Medium VOA analysis only 
$1 B$ - FORM I VOA-2

VOLATILE ORGANICS ANALYSIS DATA SHEET
EPA SAMPLE NO.

GMWPW17948
Lab Name: TESTAMERICA BURLINGTON

Lab Code: STLV Case No.: AGRA

Matrix: (SOIL/SED/WATER) Water

Sample wt/vol: $25.0 \quad(\mathrm{~g} / \mathrm{mL}) \mathrm{mL}$

Level: (TRACE/LOW/MED) TRACE

$\%$ Moisture: not dec.

GC Column: DB-624

ID $: 0.53$

Soil Extract Volume:

Purge Volume: 25.0
Contract: $8 E-00302$

Mod. Ref No.:
SDG No. : 132257
Lab Sample ID: 798629

Lab File ID: $798629 \mathrm{D} 2$

Date Received: 06/18/2009

Date Analyzed: 06/19/2009

Dilution Factor: 2.8

Soil Aliquot Volume:

$(\mathrm{mL})$

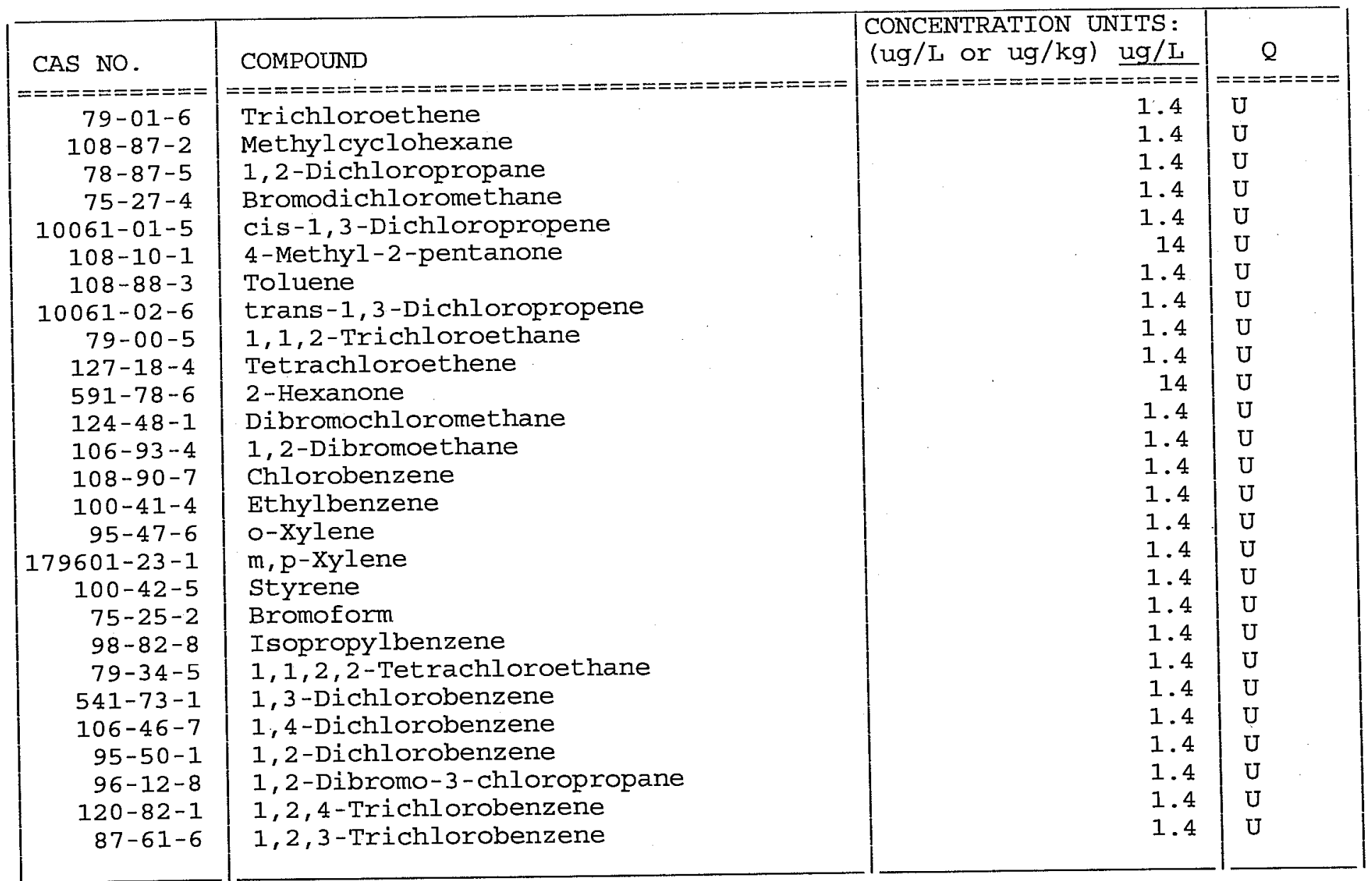


$1 A$ - FORM I VOA-1

VOLATILE ORGANICS ANALYSIS DATA SHEET
EPA SAMPLE NO. GMWPW1 7948DL
Lab Name: TESTAMERICA BURLINGTON

Lab Code: STLV Case No.: AGRA

Matrix: (SOIL/SED/WATER) Water

Sample wt/vol: 25.0

$(\mathrm{g} / \mathrm{mL}) \mathrm{mL}$

Level: (TRACE/LOW/MED) TRACE

\% Moisture: not dec.

GC Column: DB-624

ID $: 0.53$

Soil Extract Volume:

Purge Volume: 25.0
Contract: $8 \mathrm{E}-00302$

Mod. Ref No.:
SDG No.: 132257
Lab Sample ID: 798629D1

Lab File ID: $798629 \mathrm{D}$

Date Received: 06/18/2009

Date Analyzed: 06/19/2009

Dilution Factor: 27.5

Soil Aliquot Volume:

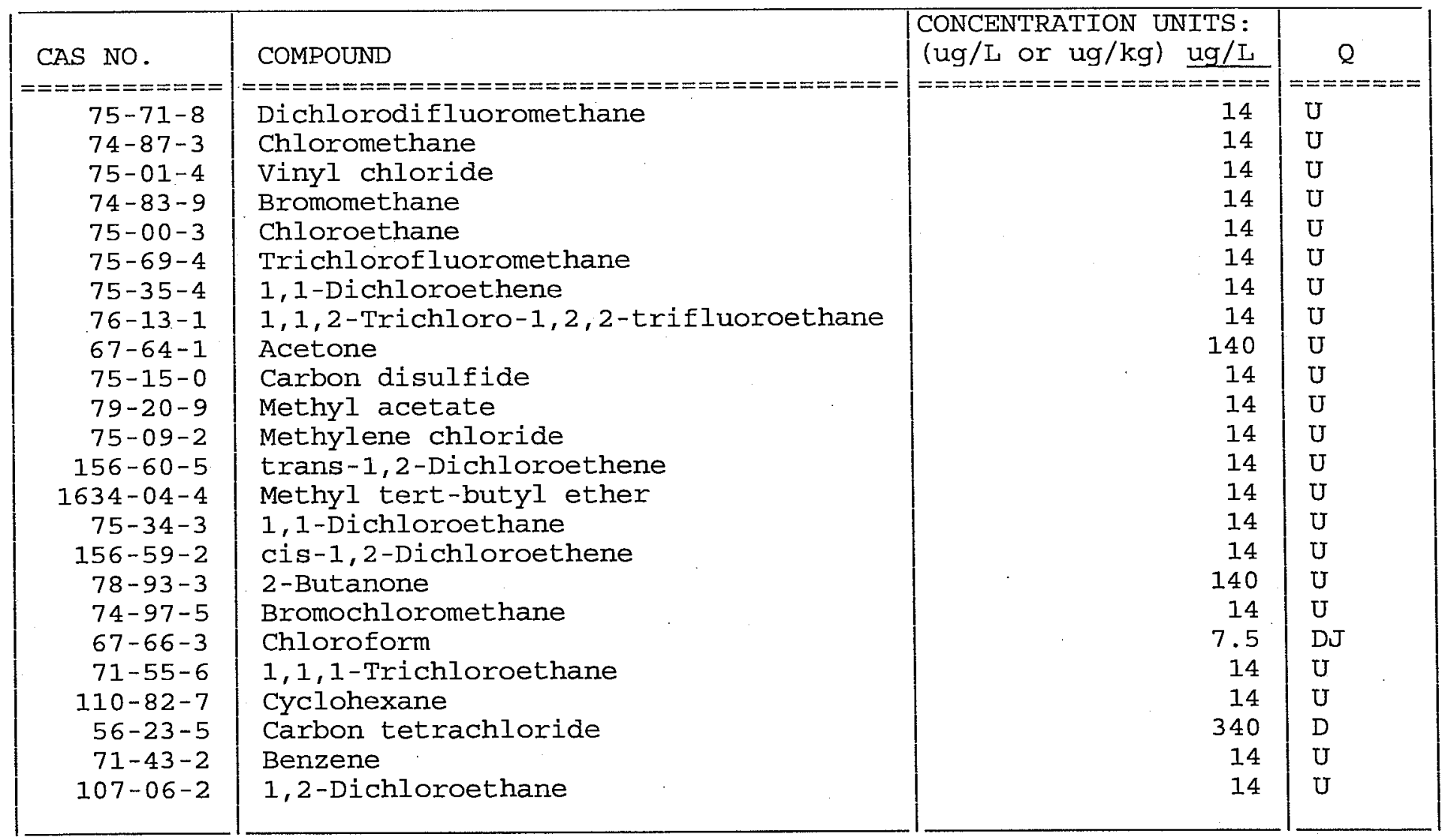

Report 1,4-Dioxane for Low-Medium. VOA analysis only 
IB - FORM I VOA-2

VOIATILE ORGANICS ANALYSIS DATA SHEET

Lab Name: TESTAMERICA BURLINGTON

Lab Code: STLV Case No.: AGRA

Matrix: (SOIL/SED/WATER) Water

Sample wt/vol: 25.0

$(\mathrm{g} / \mathrm{mL}) \mathrm{mL}$

Level : (TRACE/LOW/MED) TRACE .

$\%$ Moisture: not dec.

GC Column: DB-624

ID : 0.53

Soil Extract Volume:

Purge Volume: 25.0
Contract: 8E-00302

Mod. Ref No.:
SDG No. : 132257
Lab Sample ID: 798629D1

Lab File ID: $798629 D$

Date Received: 06/18/2009

Date Analyzed: 06/19/2009

Dilution Factor: 27.5

Soil Aliquot Volume:

(mL)

\begin{tabular}{|c|c|c|c|}
\hline CAS NO. & COMPOUND & $\begin{array}{l}\text { CONCENTRATION UNITS: } \\
(\mathrm{ug} / \mathrm{L} \text { or } \mathrm{ug} / \mathrm{kg}) \mathrm{ug} / \mathrm{L}\end{array}$ & Q \\
\hline$==========$ & 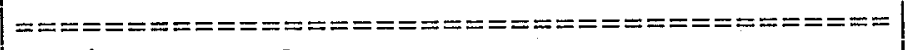 & 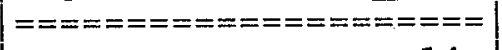 & $========$ \\
\hline $79-01-6$ & Trichloroethene & 14 & $\mathrm{U}$ \\
\hline $108-87-2$ & Methylcyclohexane & 14 & $\mathrm{U}$ \\
\hline $78-87-5$ & 1,2-Dichloropropane & 14 & $\mathrm{U}$ \\
\hline $75-27-4$ & Bromodichloromethane & 14 & U \\
\hline $10061-01-5$ & cis-1,3-Dichloropropene & 14 & $\mathrm{U}$ \\
\hline $108-10-1$ & 4-Methyl-2-pentanone & 140 & $\mathrm{U}$ \\
\hline $108-88-3$ & Toluene & 14 & $\mathrm{U}$ \\
\hline $10061-02-6$ & trans-1,3-Dichloropropene & 14 & $\mathrm{U}$ \\
\hline $79-00-5$ & $1,1,2$-Trichloroethane & 14 & $\mathrm{U}$ \\
\hline $127-18-4$ & Tetrachloroethene & 14 & $\mathrm{U}$ \\
\hline $591-78-6$ & 2-Hexanone & 140 & $\mathrm{U}$ \\
\hline $124-48-1$ & Dibromochloromethane & 14 & $\mathrm{U}$ \\
\hline $106-93-4$ & 1,2-Dibromoethane & 14 & $\mathrm{U}$ \\
\hline $108-90-7$ & Chlorobenzene & 14 & $\mathrm{U}$ \\
\hline $100-41-4$ & Ethylbenzene & 14 & $\mathrm{U}$ \\
\hline $95-47-6$ & o-Xylene & 14 & $\mathrm{U}$ \\
\hline $179601-23-1$ & $\mathrm{~m}, \mathrm{p}-\mathrm{xy}$ lene & 14 & $\mathrm{U}$ \\
\hline $100-42-5$ & Styrene & 14 & U \\
\hline $75-25-2$ & Bromoform & 14 & $\mathrm{U}$ \\
\hline $98-82-8$ & Isopropylbenzene & 14 & $\mathrm{U}$ \\
\hline $79-34-5$ & $1,1,2,2$-Tetrachloroethane & 14 & $\mathrm{U}$ \\
\hline $541-73-1$ & 1,3-Dichlorobenzene & 14 & $\mathrm{U}$ \\
\hline $106-46-7$ & 1,4-Dichlorobenzene & 14 & U \\
\hline $95-50-1$ & 1,2-Dichlorobenzene & 14 & $\mathrm{U}$ \\
\hline $96-12-8$ & 1,2-Dibromo-3-chloropropane & 14 & $\mathrm{U}$ \\
\hline $120-82-1$ & $1,2,4$-Trichlorobenzene & 14 & $\mathrm{U}$ \\
\hline $87-61-6$ & $1,2,3$-Trichlorobenzene & 14 & $\mathrm{U}$ \\
\hline
\end{tabular}


$1 A$ - FORM I VOA-I

VOLATILE ORGANICS ANALYSIS DATA SHEET

Lab Name: TESTAMERICA BURLINGTON

Lab Code: STLV Case No.: AGRA

Matrix: (SOIL/SED/WATER) Water

Sample wt/vol: $25.0 \quad(\mathrm{~g} / \mathrm{mL}) \mathrm{mL}$

Level : (TRACE/LOW/MED) TRACE

\% Moisture: not dec.

GC Column: DB-624 ID: 0.53 (mm) Dilution Factor: 1.0

Soil Extract Volume:

(uL) Soil Aliquot Volume:

Purge Volume: 25.0
Contract : 8E-00302

Mod. Ref No.:
L̇ab Sample ID: 798630

Lab File ID: 798630

Date Received: 06/18/2009

Date Analyzed: 06/19/2009

$(\mathrm{mL})$

\begin{tabular}{|c|c|c|c|}
\hline $\begin{array}{c}\text { CAS NO. } \\
========== \\
75-71-8 \\
74-87-3 \\
75-01-4 \\
74-83-9 \\
75-00-3 \\
75-69-4 \\
75-35-4 \\
76-13-1 \\
67-64-1 \\
75-15-0 \\
79-20-9 \\
75-09-2 \\
156-60-5 \\
1634-04-4 \\
75-34-3 \\
156-59-2 \\
78-93-3 \\
74-97-5 \\
67-66-3 \\
71-55-6 \\
110-82-7 \\
56-23-5 \\
71-43-2 \\
107-06-2\end{array}$ & $\begin{array}{l}\text { COMPOUND } \\
\text { Dichlorodifluoromethane } \\
\text { Chloromethane } \\
\text { Vinyl chloride } \\
\text { Bromomethane } \\
\text { Chloroethane } \\
\text { Trichlorofluoromethane } \\
1,1-D i c h l o r o e t h e n e \\
1,1,2-T r i c h l o r o-1,2,2-t r i f l u o r o e t h a n e \\
\text { Acetone } \\
\text { Carbon disulfide } \\
\text { Methyl acetate } \\
\text { Methylene chloride } \\
\text { trans-1,2-Dichloroethene } \\
\text { Methyl tert-butyl ether } \\
1,1-D i c h l o r o e t h a n e \\
\text { cis-1,2-Dichloroethene } \\
2-\text { Butanone } \\
\text { Bromochloromethane } \\
\text { Chloroform } \\
1,1,1-\text { Trichloroethane } \\
\text { Cyclohexane } \\
\text { Carbon tetrachloride } \\
\text { Benzene } \\
1,2-D i c h l o r o e t h a n e\end{array}$ & 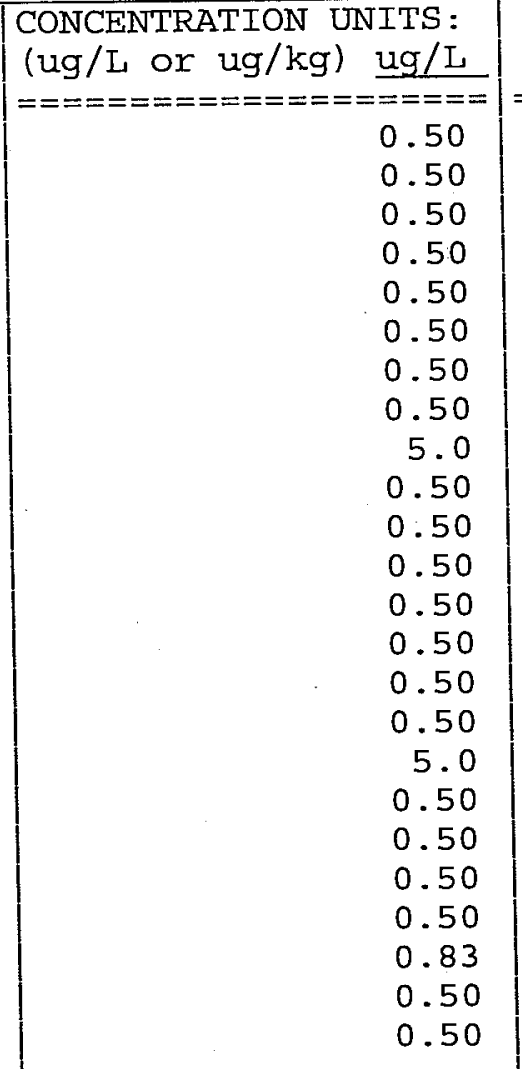 & \begin{tabular}{|c}
$======$ \\
$U$ \\
$U$ \\
$U$ \\
$U$ \\
$U$ \\
$U$ \\
$U$ \\
$U$ \\
$U$ \\
$U$ \\
$U$ \\
$U$ \\
$U$ \\
$U$ \\
$U$ \\
$U$ \\
$U$ \\
$U$ \\
$U$ \\
$U$ \\
$U$ \\
$U$ \\
$U$ \\
$U$
\end{tabular} \\
\hline
\end{tabular}

Report 1,4-Dioxane for Low-Medium VOA analysis only 
$1 B$ - FORM I VOA-2

VOLATILE ORGANICS ANALYSIS DATA SHEET
EPA SAMPLE NO.
Lab Name: TESTAMERICA BURLINGTON

Lab Code: STLV Case No.: AGRA

Matrix: (SOIL/SED/WATER) Water

Sample wt/vol: 25.0

$(\mathrm{g} / \mathrm{mL}) \mathrm{mL}$

Level : (TRACE/LOW/MED) TRACE

\% Moisture: not dec.

GC Column: DB-624

Soil Extract Volume:

ID : 0.53

(mm)

(u工)

Contract: 8E-00302

Mod. Ref No.:

Lab Sample ID: 798630

Lab File ID: 798630

Dilution Factor: 1.0

Soil Aliquot Volume:
SDG No.: 132257

Purge Volume: 25.0

Date Received: 06/18/2009

Date Analyzed: 06/19/2009

(mL)

\begin{tabular}{|c|c|c|c|}
\hline CAS NO. & COMPOUND & $\begin{array}{l}\text { CONCENTRATION UNITS: } \\
(\mathrm{ug} / \mathrm{L} \text { or } \mathrm{ug} / \mathrm{kg}) \mathrm{ug} / \mathrm{L}\end{array}$ & Q \\
\hline$===========$ & 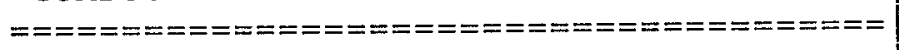 & 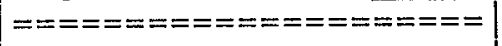 & $========$ \\
\hline $79-01-6$ & Trichloroethene & 0.50 & $\mathrm{U}$ \\
\hline $108-87-2$ & Methylcyclohexane & 0.50 & $\mathrm{U}$ \\
\hline $78-87-5$ & 1,2-Dichloropropane & 0.50 & $\mathrm{U}$ \\
\hline $75-27-4$ & Bromodichloromethane & 0.50 & $\mathrm{U}$ \\
\hline $10061-01-5$ & cis-1,3-Dichloropropene & 0.50 & $\mathrm{U}$ \\
\hline $108-10-1$ & 4-Methyl-2-pentanone & 5.0 & $\mathrm{U}$ \\
\hline $108-88-3$ & Toluene & 0.50 & $\mathrm{U}$ \\
\hline $10061-02-6$ & trans-1,3-Dichloropropene & 0.50 & U \\
\hline $79-00-5$ & $1,1,2$-Trichloroethane & 0.50 & $\mathrm{U}$ \\
\hline $127-18-4$ & Tetrachloroethene & 0.50 & $\mathrm{U}$ \\
\hline $591-78-6$ & 2 -Hexanone & 5.0 & $\mathrm{U}$ \\
\hline $124-48-1$ & Dibromochloromethane & 0.50 & U \\
\hline $106-93-4$ & 1,2-Dibromoethane & 0.50 & $\mathrm{U}$ \\
\hline $108-90-7$ & Chlorobenzene & 0.50 & $\mathrm{U}$ \\
\hline $100-41-4$ & Ethylbenzene & 0.50 & U \\
\hline $95-47-6$ & o-xylene & 0.50 & U \\
\hline $179601-23-1$ & $\mathrm{~m}, \mathrm{p}$-Xylene & 0.50 & $\mathrm{U}$ \\
\hline $100-42-5$ & Styrene & 0.50 & U \\
\hline $75-25-2$ & Bromoform & 0.50 & U \\
\hline $98-82-8$ & Isopropylbenzene & 0.50 & $\mathrm{U}$ \\
\hline $79-34-5$ & $1,1,2,2$-Tetrachloroethane & 0.50 & $\mathrm{U}$ \\
\hline $541-73-1$ & 1,3-Dichlorobenzene & 0.50 & $U$ \\
\hline $106-46-7$ & 1,4-Dichlorobenzene & 0.50 & $\mathrm{U}$ \\
\hline $95-50-1$ & 1,2-Dichlorobenzene & 0.50 & $\mathrm{U}$ \\
\hline $96-12-8$ & 1,2-Dibromo-3-chloropropane & 0.50 & $\mathrm{U}$ \\
\hline $120-82-1$ & $1,2,4$-Trichlorobenzene & 0.50 & $\mathrm{U}$ \\
\hline $87-61-6$ & 1,2,3-Trichlorobenzene & 0.50 & U \\
\hline
\end{tabular}


IA - FORM I VOA-1

VOLATILE ORGANICS ANALYSIS DATA SHEET.
EPA SAMPLE NO.

AGQCTBW1 7959
Lab Name: TESTAMERICA BURLINGTON

Lab Code: STLV Case No.: AGRA

Matrix: (SOIL/SED/WATER) water

Sample wt/vol: 25.0

$(\mathrm{g} / \mathrm{mL}) \mathrm{mL}$

Level: (TRACE/LOW/MED) TRACE

\% Moisture: not dec.

GC Column: DB-624

ID : 0.53

Soil Extract Volume:

Purge Volume: 25.0
Contract: 8E-00302

Mod. Ref No.:
SDG No.: 132257
Lab Sample ID: 798631

Lab File ID: 798631

Date Received: 06/18/2009

Date Analyzed: 06/19/2009

Dilution Factor: 1.0

(uL) Soil Aliquot Volume:

(uL)

\begin{tabular}{|c|c|c|c|}
\hline CAS NO. & COMPOUND & $\begin{array}{l}\text { CONCENTRATION UNITS: } \\
(\mathrm{ug} / \mathrm{L} \text { or } \mathrm{ug} / \mathrm{kg}) \mathrm{ug} / \mathrm{L}\end{array}$ & $Q$ \\
\hline$==========$ & 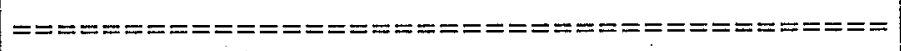 & 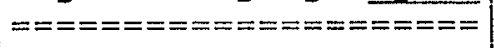 & $=======$ \\
\hline $75-71-8$ & Dichlorodifluoromethane & 0.50 & $\mathrm{U}$ \\
\hline $74-87-3$ & Chloromethane & 0.50 & $\mathrm{U}$ \\
\hline $75-01-4$ & Vinyl chloride & 0.50 & $\mathrm{U}$ \\
\hline $74-83-9$ & Bromomethane & 0.50 & $\mathrm{U}$ \\
\hline $75-00-3$ & Chloroethane & 0.50 & $\mathrm{U}$ \\
\hline $75-69-4$ & Trichlorofluoromethane & 0.50 & $\mathrm{U}$ \\
\hline $75-35-4$ & 1,1 -Dichloroethene & 0.50 & $\mathrm{U}$ \\
\hline $76-13-1$ & $1,1,2$-Trichloro-1,2,2-trifluoroethane & 0.50 & $\mathrm{U}$ \\
\hline $67-64-1$ & Acetone & 8.8 & \\
\hline $75-15-0$ & Carbon disulfide & 0.50 & $\mathrm{U}$ \\
\hline $79-20-9$ & Methyl acetate & 0.50 & $\mathrm{U}$ \\
\hline $75-09-2$ & Methylene chloride & 0.50 & $\mathrm{U}$ \\
\hline $156-60-5$ & trans-1,2-Dichloroethene & 0.50 & $\mathrm{U}$ \\
\hline $1634-04-4$ & Methyl tert-butyl ether & 0.50 & $\mathrm{U}$ \\
\hline $75-34-3$ & 1,1-Dichloroethane & 0.50 & $\mathrm{U}$ \\
\hline $156-59-2$ & cis-1,2-Dichloroethene & 0.50 & $\mathrm{U}$ \\
\hline $78-93-3$ & 2-Butanone & 0.97 & $J$ \\
\hline $74-97-5$ & Bromochloromethane & 0.50 & $\mathrm{U}$ \\
\hline $67-66-3$ & Chloroform & 0.50 & $\mathrm{U}$ \\
\hline $71-55-6$ & 1,1,1-Trichloroethane & 0.50 & $\mathrm{U}$ \\
\hline $110-82-7$ & Cyclohexane & 0.50 & $\mathrm{U}$ \\
\hline $56-23-5$ & Carbon tetrachloride & 0.50 & $\mathrm{U}$ \\
\hline $71-43-2$ & Benzene & 0.50 & $\mathrm{U}$ \\
\hline $107-06-2$ & 1,2-Dichloroethane & 0.50 & $\mathrm{U}$ \\
\hline
\end{tabular}

Report 1,4-Dioxane for Low-Medium VOA analysis only 
IB - FORM I VOA-2.

VOLATILE ORGANICS ANALYSIS DATA SHEET

EPA SAMPIE NO.

Lab Name: TESTAMERICA BURLINGTON

Lab Code: STLV Case No.: AGRA

Matrix: (SOIL/SED/WATER) water

Sample wt/vol: 25.0

$(\mathrm{g} / \mathrm{mL}) \mathrm{mL}$

Level : (TRACE/LOW/MED) TRACE

\% Moisture: not dec.

GC Column: DB-624

Soil Extract Volume:

ID $: 0.53$

(mm)

(uL)

Contract: 8E-00302

Mod. Ref No.:

Lab Sample ID: 798631

Lab File ID: 798631

Dilution Factor: 1.0

Soil Aliquot Volume:
SDG No.: 132257

Purge Volume: 25.0

Date Received: 06/18/2009

Date Analyzed: 06/19/2009

(uL)

(mL)

\begin{tabular}{|c|c|c|c|}
\hline CAS NO. & COMPOUND & $\begin{array}{l}\text { CONCENTRATION UNITS: } \\
(\mathrm{ug} / \mathrm{L} \text { or } \mathrm{ug} / \mathrm{kg}) \mathrm{ug} / \mathrm{L}\end{array}$ & Q \\
\hline$===========$ & 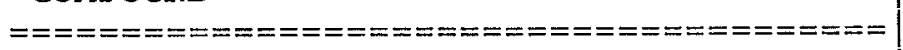 & $===================$ & $=======$ \\
\hline $79-01-6$ & Trichloroethene & 0.50 & $\mathrm{U}$ \\
\hline $108-87-2$ & Methylcyclohexane & 0.50 & $\mathrm{U}$ \\
\hline $78-87-5$ & 1,2-Dichloropropane & 0.50 & $\mathrm{U}$ \\
\hline $75-27-4$ & Bromodichloromethane & 0.50 & $\mathrm{U}$ \\
\hline $10061-01-5$ & cis-1,3-Dichloropropene & 0.50 & $\mathrm{U}$ \\
\hline $108-10-1$ & 4-Methyl-2-pentanone & 5.0 & $\mathrm{U}$ \\
\hline $108-88-3$ & Toluene & 0.50 & $\mathrm{U}$ \\
\hline $10061-02-6$ & trans-1,3-Dichloropropene & 0.50 & $\mathrm{U}$ \\
\hline $79-00-5$ & 1,1,2-Trichloroethane & 0.50 & $\mathrm{U}$ \\
\hline $127-18-4$ & Tetrachloroethene & 0.53 & \\
\hline $591-78-6$ & 2-Hexanone & 5.0 & $\overline{\mathrm{U}}$ \\
\hline $124-48-1$ & Dibromochloromethane & 0.50 & $\mathrm{U}$ \\
\hline $106-93-4$ & 1,2-Dibromoethane & 0.50 & $\mathrm{U}$ \\
\hline $108-90-7$ & Chlorobenzene & 0.50 & $\mathrm{U}$ \\
\hline $100-41-4$ & Ethylbenzene & 0.50 & $\mathrm{U}$ \\
\hline $95-47-6$ & o-Xylene & 0.50 & U \\
\hline $179601-23-1$ & $\mathrm{~m}, \mathrm{p}$-Xylene & 0.50 & $\mathrm{U}$ \\
\hline $100-42-5$ & Styrene & 0.94 & \\
\hline $75-25-2$ & Bromoform & 0.50 & $\overline{\mathrm{U}}$ \\
\hline $98-82-8$ & Isopropylbenzene & 0.50 & $\mathrm{U}$ \\
\hline $79-34-5$ & $1,1,2,2$-Tetrachloroethane & 0.50 & $\mathrm{U}$ \\
\hline $541-73-1$ & 1,3-Dichlorobenzene & 0.50 & $\mathrm{U}$ \\
\hline $106-46-7$ & 1,4-Dichlorobenzene & 0.50 & U \\
\hline $95-50-1$ & 1,2-Dichlorobenzene & 0.50 & U \\
\hline $96-12-8$ & 1,2-Dibromo-3-chloropropane & 0.50 & $\mathrm{U}$ \\
\hline $120-82-1$ & $1,2,4$-Trichlorobenzene & 0.50 & $\mathrm{U}$ \\
\hline $87-61-6$ & $1,2,3$-Trichlorobenzene & 0.50 & $\mathrm{U}$ \\
\hline
\end{tabular}


$1 A$ - FORM I VOA-I

VOLATILE ORGANICS ANALYSIS DATA SHEET

EPA SAMPLE NO.

VHBLKO1

Lab Name: TESTAMERICA BURLINGTON

Lab Code: STLV Case No.: AGRA

Matrix: (SOIL/SED/WATER) Water

Sample wt/vol: $25.0(\mathrm{~g} / \mathrm{mL}) \mathrm{mL}$

Level: (TRACE/LOW/MED) TRACE

$\%$ Moisture: not dec.

GC Column: DB-624

ID $: 0.53$

Soil Extract Volume:

Purge Volume: 25.0
Contract : $8 \mathrm{E}-00302$

Mod. Ref No.:
SDG NO.: 132257
Lab Sample ID: 798632

Lab File ID: 798632

Date Received:

Date Analyzed: 06/19/2009

Dilution Factor: 1.0

Soil Aliquot Volume:

(uL)

\begin{tabular}{|c|c|c|c|}
\hline \begin{tabular}{|c|} 
CAS NO. \\
$==========$ \\
$75-71-8$ \\
$74-87-3$ \\
$75-01-4$ \\
$74-83-9$ \\
$75-00-3$ \\
$75-69-4$ \\
$75-35-4$ \\
$76-13-1$ \\
$67-64-1$ \\
$75-15-0$ \\
$79-20-9$ \\
$75-09-2$ \\
$156-60-5$ \\
$1634-04-4$ \\
$75-34-3$ \\
$156-59-2$ \\
$78-93-3$ \\
$74-97-5$ \\
$67-66-3$ \\
$71-55-6$ \\
$110-82-7$ \\
$56-23-5$ \\
$71-43-2$ \\
$107-06-2$
\end{tabular} & $\begin{array}{l}\text { COMPOUND } \\
============================= \\
\text { Dichlorodifluoromethane } \\
\text { Chloromethane } \\
\text { Vinyl chloride } \\
\text { Bromomethane } \\
\text { Chloroethane } \\
\text { Trichlorofluoromethane } \\
\text { 1,1-Dichloroethene } \\
\text { 1,1,2-Trichloro-1, } 2,2-t r i f l u o r o e t h a n e \\
\text { Acetone } \\
\text { Carbon disulfide } \\
\text { Methyl acetate } \\
\text { Methylene chloride } \\
\text { trans-1,2-Dichloroethene } \\
\text { Methyl tert-butyl ether } \\
1,1-D i c h l o r o e t h a n e \\
\text { cis-1,2-Dichloroethene } \\
2-\text { Butanone } \\
\text { Bromochloromethane } \\
\text { Chloroform } \\
1,1,1-T r i c h l o r o e t h a n e \\
\text { Cyclohexane } \\
\text { Carbon tetrachloride } \\
\text { Benzene } \\
1,2-D i c h l o r o e t h a n e \\
\end{array}$ & \begin{tabular}{|c} 
CONCENTRATION UNITS: \\
(ug/L or ug/kg) \\
ug $/ \mathrm{L} / \mathrm{L}$ \\
$================$ \\
0.50 \\
0.50 \\
0.50 \\
0.50 \\
0.50 \\
0.50 \\
0.50 \\
0.50 \\
5.0 \\
0.50 \\
0.50 \\
0.50 \\
0.50 \\
0.50 \\
0.50 \\
0.50 \\
5.0 \\
0.50 \\
0.50 \\
0.50 \\
0.50 \\
0.50 \\
0.50 \\
0.50
\end{tabular} & $\begin{array}{l}\text { Q }========= \\
U \\
U \\
U \\
U \\
U \\
U \\
U \\
U \\
U \\
U \\
U \\
U \\
U \\
U \\
U \\
U \\
U \\
U \\
U \\
U \\
U \\
U \\
U \\
U\end{array}$ \\
\hline
\end{tabular}

Report 1,4-Dioxane for Low-Medium VOA analysis only 
Lab Name: TESTAMERICA BURLINGTON

Lab Code: STLV Case No.: AGRA

Matrix: (SOIL/SED/WATER) Water

Sample wt/vol: 25.0

$(\mathrm{g} / \mathrm{mL}) \mathrm{mL}$

Level : (TRACE/LOW/MED) TRACE

\% Moisture: not dec.

GC Column: DB-624

Soil Extract Volume:

ID $: 0.53$

(mm)

(uL)

Contract: $8 E-00302$

Mod. Ref No.:

Lab Sample ID: 798632

Lab File ID: 798632

Date Received:

Dilution Factor: 1.0

Soil Aliquot Volume:

Purge Volume: 25.0

(mL)

Date Analyzed: 06/19/2009

(uL)

\begin{tabular}{|c|c|c|c|}
\hline CAS NO. & COMPOUND & $\begin{array}{l}\text { CONCENTRATION UNITS: } \\
(\mathrm{ug} / \mathrm{L} \text { or } \mathrm{ug} / \mathrm{kg} \text { ) ug/L }\end{array}$ & Q \\
\hline$==========$ & 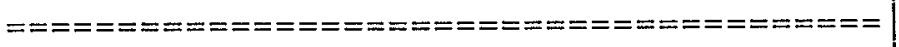 & 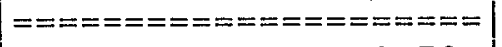 & $=======$ \\
\hline $79-01-6$ & Trichloroethene & 0.50 & $\mathrm{U}$ \\
\hline $108-87-2$ & Methylcyclohexane & 0.50 & $\mathrm{U}$ \\
\hline $78-87-5$ & 1,2-Dichloropropane & 0.50 & $\mathrm{U}$ \\
\hline $75-27-4$ & Bromodichloromethane & 0.50 & $\mathrm{U}$ \\
\hline $10061-01-5$ & cis-1,3-Dichloropropene & 0.50 & $\mathrm{U}$ \\
\hline $108-10-1$ & 4-Methyl-2-pentanone & 5.0 & $\mathrm{U}$ \\
\hline $108-88-3$ & Toluene & 0.50 & $\mathrm{U}$ \\
\hline $10061-02-6$ & trans-1,3-Dichloropropene & 0.50 & $\mathrm{U}$ \\
\hline $79-00-5$ & 1,1,2-Trichloroethane & 0.50 & $\mathrm{U}$ \\
\hline $127-18-4$ & Tetrachloroethene & 0.50 & $\mathrm{U}$ \\
\hline $591-78-6$ & 2-Hexanone & 5.0 & $\mathrm{U}$ \\
\hline $124-48-1$ & Dibromochloromethane & 0.50 & $\mathrm{U}$ \\
\hline $106-93-4$ & 1,2-Dibromoethane & 0.50 & $\mathrm{U}$ \\
\hline $108-90-7$ & Chlorobenzene & 0.50 & $\mathrm{U}$ \\
\hline $100-41-4$ & Ethylbenzene & 0.50 & $\mathrm{U}$ \\
\hline $95-47-6$ & o-Xylene & 0.50 & $\mathrm{U}$ \\
\hline $179601-23-1$ & $\mathrm{~m}, \mathrm{p}$-Xylene & 0.50 & $\mathrm{U}$ \\
\hline $100-42-5$ & Styrene & 0.50 & $\mathrm{U}$ \\
\hline $75-25-2$ & Bromoform & 0.50 & $\mathrm{U}$ \\
\hline $98-82-8$ & Isopropylbenzene & 0.50 & $\mathrm{U}$ \\
\hline $79-34-5$ & $1,1,2,2$-Tetrachloroethane & 0.50 & U \\
\hline $541-73-1$ & 1,3-Dichlorobenzene & 0.50 & $\mathrm{U}$ \\
\hline $106-46-7$ & 1,4-Dichlorobenzene & 0.50 & $\mathrm{U}$ \\
\hline $95-50-1$ & 1,2-Dichlorobenzene & 0.50 & $\mathrm{U}$ \\
\hline $96-12-8$ & 1,2-Dibromo-3-chloropropane & 0.50 & U \\
\hline $120-82-1$ & $1,2,4$-Trichlorobenzene & 0.50 & $\mathrm{U}$ \\
\hline $87-61-6$ & 1,2,3-Trichlorobenzene & 0.50 & $\mathrm{U}$ \\
\hline
\end{tabular}




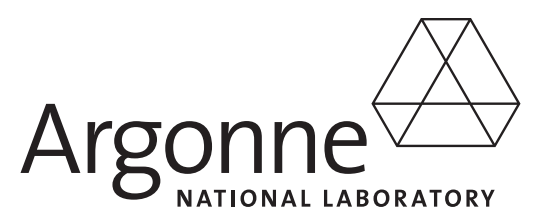

\section{Environmental Science Division}

Argonne National Laboratory

9700 South Cass Avenue, Bldg. 203

Argonne, IL 60439-4843

www.anl.gov 